\title{
Estrutura da inflação brasileira: determinantes e desagregação do IPCA *
}

\author{
Thiago Sevilhano Martinez \\ Vinícius dos Santos Cerqueira ${ }^{* * *}$
}

\begin{abstract}
Resumo
Este artigo tem por objetivo discutir os determinantes e a decomposição da inflação brasileira medida pelo IPCA nos anos de 2000 a 2009. Foram construídas 22 séries desagregadas, a classificação por segmentos, resultante da combinação da classificação bens comercializáveis/não comercializáveis/ monitorados com os nove grupos do IPCA (alimentação e bebidas, habitação, artigos de residência, vestuário, transportes, saúde e cuidados pessoais, despesas pessoais, educação e comunicação). Os segmentos que mais influenciaram a inflação são ordenados pelo denominado Índice de Pressão sobre a Meta de Inflação (IPMI), criado para medir o impacto de cada agrupamento sobre o IPCA. São apresentados os resultados de um modelo econométrico, com dados mensais de 1999 a 2009, para estimar os determinantes macroeconômicos da inflação desagregada nas 22 séries. Os determinantes dos segmentos mais influentes são explorados a partir dos resultados do modelo econométrico. Por fim, são levantadas algumas implicações para políticas de combate à inflação.
\end{abstract}

Palavras-chave: Decomposição da inflação; Índice de pressão sobre a meta de inflação; Classificação por segmentos; IPCA, Função de transferência.

\begin{abstract}
Structure of Brazilian inflation: determinants and disaggregation of the extended National Consumer Price Index (IPCA)

This paper aims to discuss the determinants of Brazilian inflation measured by the Extended National Consumer Price Index (IPCA) from 2000 to 2009. We built 22 disaggregated series, the segments classification, crossing the classification in tradables/non-tradables/monitored prices with the main groups of the IPCA (food and beverages, housing, household goods, clothing, transportation, health and personal care, personal expenses, education and communication). Segments with the most influence on inflation are ordered according to the Inflation Targeting Pressure Index (ITPI), designed to measure the impact of each prices group on the IPCA. The paper also presents the results from an econometric model to estimate the macroeconomic determinants of inflation in the 22 disaggregated series, using monthly data from 1999 to 2009. The determinants of most influential segments are explored based on the results of the econometric model. Finally, the implications for inflation policies are discussed.
\end{abstract}

Keywords: Inflation decomposition; Inflation targeting pressure index; Segment classification; IPCA - Extended National Consumer Price Index; Transfer function models.

JEL E310, E640, E650, C220.

\footnotetext{
* Trabalho recebido em 1 de novembro de 2011 e aprovado em 20 de março de 2012.

** Técnico de Planejamento e Pesquisa do Instituto de Pesquisa Econômica e Aplicada (Ipea), Brasília, DF, Brasil. E-mail: thiago.martinez@ipea.gov.br.

*** Técnico de Planejamento e Pesquisa do Instituto de Pesquisa Econômica e Aplicada (Ipea), Brasília, DF, Brasil. E-mail: vinicius.cerqueira@ipea.gov.br.
} 


\section{Introdução}

Em termos conceituais, a taxa de inflação é um agregado macroeconômico que pretende indicar o efeito médio sobre a economia de um fenômeno complexo: o aumento de preços dos diversos bens que a compõem. Concretamente, índices de inflação podem ser construídos a partir de variadas cestas de bens, conforme os preços relevantes para os grupos que se queira considerar - consumidores, produtores de um setor ou da economia em geral, residentes de uma região específica. Os modelos macroeconômicos usualmente tratam a inflação como uma grandeza única, buscando quais são seus determinantes e as políticas mais adequadas para contê-la.

Contudo, muito da dinâmica por trás do fenômeno inflacionário se perde com a agregação, uma vez que os preços dos bens têm comportamentos específicos que podem ser muito discrepantes entre si. Então, conhecer melhor essa dinâmica subjacente à inflação é um passo necessário na avaliação de seus determinantes e dos efeitos sobre a inflação de diferentes políticas econômicas.

A maioria dos trabalhos relacionados à dinâmica inflacionária brasileira é baseada na estimação da curva de Phillips ${ }^{1}$. Considerando o período posterior à implementação do regime de metas para a inflação, os resultados empíricos destacam a importância da inércia, das expectativas e do repasse cambial para a explicação da trajetória da inflação. Os trabalhos que estimam modelos do tipo Non-Accelerating Inflation Rate of Unemployment (NAIRU) mostram que não se pode rejeitar o trade-off entre inflação e desemprego. Por outro lado, os modelos que utilizam o hiato do produto têm mostrado parâmetros insignificantes relacionados a esta variável.

Os artigos que analisam a inflação brasileira recente e sob uma perspectiva desagregada ainda são poucos. Em geral, trabalham com a decomposição do Banco Central do Brasil (BCB) para o Índice Nacional de Preços ao Consumidor Amplo (IPCA) de acordo com o tipo de precificação em três grupos (bens comercializáveis, não comercializáveis e monitorados) ou em dois grupos (bens livres e monitorados).

Carneiro et al. (2002) analisam o repasse cambial para a inflação desagregando o IPCA em livres e administrados. Os autores também trabalham com três subgrupos do IPCA livre: produtos industrializados, serviços e alimentos (exceto industrializados). Os resultados apontam para evidência de não linearidade do repasse cambial para o IPCA. Nas especificações lineares, o repasse cambial seria significativo para os preços livres (sobretudo o subgrupo industrializados) e nulo para os administrados. Nas especificações não lineares, no entanto, os

(1) Para uma revisão detalhada da literatura sobre estimações da curva de Phillips para a economia brasileira, ver Sachsida, Ribeiro e dos Santos (2009) e Sachsida e Mendonça (2009). 
resultados mostram impacto significativo do repasse cambial tanto para os preços livres (e os subgrupos) como para os administrados.

Muinhos e Alves (2003) apresentam uma especificação da curva de Phillips para avaliar os efeitos de políticas anti-inflacionárias. As estimações consideram apenas os preços livres do IPCA. Os fatores potenciais causadores da variação dos preços são: inércia, repasse cambial, ciclo econômico e expectativas. Utilizando dados trimestrais de 1995:01 a 2001:03, os autores mostram que o repasse cambial caiu de $51 \%$ para $6 \%$ com a introdução do regime de metas. Adicionalmente, apresentam evidência de que a importância das expectativas aumentou depois de 1999.

Schwartzman (2006) realiza estimativas para uma curva de Phillips na forma reduzida para os preços de bens comercializáveis, não comercializáveis e monitorados. Os resultados mostram que o impacto direto da taxa de câmbio é significativo sobre os preços de bens comercializáveis e monitorados. O autor considera um impacto indireto da desvalorização cambial sobre os preços dos não comercializáveis. O canal de transmissão seria através da inflação do IPCA total defasado, avaliado como inércia nos modelos e que teve impacto significativo sobre os preços dos não comercializáveis. Essa variável foi significativa para os comercializáveis e para os monitorados. Por fim, a capacidade instalada na indústria foi utilizada para identificar o efeito do ciclo econômico sobre os preços. Esse efeito foi significativo apenas em relação aos preços dos não comercializáveis ${ }^{2}$. Um resultado marcante desse trabalho é a não significância dos parâmetros relacionados à expectativa de inflação nos modelos dos três grupos.

Tombini e Alves (2006) utilizam uma curva de Phillips híbrida para analisar a dinâmica dos preços livres do IPCA no período 1996-2006. A estimação por filtro de Kalman permite verificar a evolução dos parâmetros do modelo. Os resultados mostram que os preços livres respondem basicamente à inflação passada, à inflação esperada e ao repasse cambial, sendo que os coeficientes sofrem oscilações substanciais em 1999 e 2002. O coeficiente da inflação passada sofre uma redução em 1999 e se recupera em parte depois de 2002. A importância da inflação esperada cresce em 1999 e sofre uma pequena oscilação negativa depois de 2002. No entanto, o que mais chama a atenção é o fato de o repasse cambial ser praticamente nulo durante 1999 e 2002.

O presente estudo pretende avançar em relação a essa literatura com duas novidades metodológicas. Primeiro, propõe uma análise em um nível menor de agregação do IPCA. Para tanto, a classificação do BCB em bens comercializáveis, não comercializáveis e monitorados foi cruzada com os nove grupos do IPCA,

(2) Não obstante, os testes das restrições de longo prazo não rejeitam a hipótese de verticalidade da curva de Phillips. 
resultando na denominada classificação por segmentos. Tal classificação é composta por 22 séries, que foram calculadas para o período de agosto de 1999 a dezembro de 2009. Os impactos de variáveis macroeconômicas relevantes sobre a inflação de cada um dos 22 segmentos são identificados por meio de modelos de função de transferência estimados pela metodologia de Box e Jenkins multivariada. As séries utilizadas têm frequência mensal e foram trabalhadas em dois cortes amostrais devido a diferenças na disponibilidade de dados, de agosto de 1999 a dezembro de 2009 e de julho de 2001 a dezembro de 2009.

Segundo, é apresentado o Índice de Pressão sobre a Meta de Inflação (IPMI), criado para medir a contribuição de cada bem ou agrupamento de bens para a inflação do IPCA. Por meio do IPMI, são apontados os segmentos que mais afetaram a inflação a cada ano, de 2000 a 2009. A associação dessa análise descritiva com os resultados do modelo econométrico permite uma descrição coerente da estrutura da inflação brasileira e sua dinâmica nos dez anos de vigência do regime de metas para a inflação.

O texto divide-se em quatro seções. Após esta introdução, a segunda seção é dividida em três partes. Na primeira, é apresentado o procedimento para a construção na classificação por segmentos, na segunda, o Índice de Pressão sobre a Meta de Inflação, e, na terceira parte, desenvolve-se uma análise descritiva do IPCA de 2000 a 2009 por meio da aplicação do índice às séries de inflação por segmentos. A terceira seção do texto mostra o modelo econométrico e também se subdivide em três partes. A primeira descreve as variáveis explicativas adotadas nas regressões, a segunda explica o modelo e a terceira discute os resultados, relacionando-os à abordagem descritiva da seção anterior. Por fim, as considerações finais reúnem os principais resultados e levantam algumas de suas implicações em termos de políticas de combate à inflação e eficácia do regime de metas.

\section{Análise do IPCA desagregado}

\subsection{Classificação do IPCA por segmentos}

As séries de inflação utilizadas no artigo, denominadas classificação por segmentos, foram obtidas pelo cruzamento de dados desagregados do IPCA divulgados pelo Instituto Brasileiro de Geografia e Estatística (IBGE) com as séries do BCB que decompõem o IPCA em três agrupamentos conforme o tipo de precificação.

Além do índice geral, o IPCA é reportado pelo IBGE em quatro níveis de agregação: grupos, subgrupos, itens e subitens. O grupo é o nível de agregação mais elevado, constituído de nove categorias: alimentação e bebidas, habitação, artigos de residência, vestuário, transportes, saúde e cuidados pessoais, despesas pessoais, educação e comunicação. O subitem é o nível de menor agregação, com 
384 categorias, e corresponde a bens e serviços específicos. O peso de cada subitem do IPCA é baseado na cesta de consumo típica das famílias brasileiras com renda de até 40 salários mínimos, de acordo com a Pesquisa de Orçamentos Familiares (POF). Assim, os pesos das categorias de agregação mais elevadas, como os grupos, são dados pela soma dos pesos dos subitens que as compõem.

A decomposição do IPCA pelo BCB por tipo de precificação abrange três categorias: bens comercializáveis, não comercializáveis e monitorados. Essas séries são constituídas a partir da agregação de subitens do IPCA classificados pelo BCB em cada uma das três categorias. Os bens comercializáveis são aqueles muito afetados pelo comércio externo, ou porque boa parte de sua produção interna é exportada, ou porque as importações respondem por parcela significativa da oferta interna. Os bens não comercializáveis, incluindo serviços, são aqueles produzidos no país e voltados para o mercado interno. Já os chamados bens monitorados ou administrados por contrato são as tarifas públicas e outros preços que sofrem interferência governamental direta, como a gasolina. O Apêndice A apresenta os itens e subitens classificados pelo BCB como comercializáveis, não comercializáveis e monitorados.

A classificação por segmentos foi construída agregando subitens que possuíam a mesma classificação em grupos (critério IBGE) e em tipo de precificação (critério $\mathrm{BCB})^{3}$. Resultaram 22 séries, que foram computadas para o período de agosto de 1999 até dezembro de 2009 em frequência mensal. As séries estão no Apêndice B e podem ser obtidas em formato eletrônico mediante contato com os autores.

Foram duas as razões para a escolha desse período. O primeiro motivo é a coincidência com o período de vigência do atual tripé da política macroeconômica brasileira, composto por câmbio flutuante, por superávits primários na política fiscal e pelo regime de metas para a inflação na política monetária.

Em segundo lugar, estão as mudanças metodológicas no cálculo do IPCA, promovidas nos meses em que o IBGE atualizou a estrutura de pesos seguindo as novas versões da POF. A atual estrutura de ponderação foi estabelecida em julho de 2006, de acordo com a POF de 2002-2003. A estrutura anterior, que seguiu até junho de 2006, foi instituída em agosto de 1999 seguindo a POF de 1995-1996. Na mudança ocorrida no meio de 2006, deu-se uma redução considerável no número de subitens do IPCA, de 512 para 384, principalmente pela exclusão de subitens com peso muito pequeno e agregação de subitens semelhantes, apesar de serem incluídos alguns novos conforme mudanças nos padrões de consumo. Contudo, a

(3) Agradecemos ao Departamento Econômico (DEPEC) do BCB, que prontamente nos forneceu a classificação dos subitens em bens comercializáveis, não comercializáveis e monitorados, o que permitiu fazer a ligação com os grupos do IPCA. 
estrutura dos níveis de agregação mais elevados foi pouco alterada, de maneira que não houve descontinuidade de séries no nível de agregação adotado nesse artigo ${ }^{4}$. Já na mudança de meados de 1999, as alterações foram mais importantes, inclusive com o desmembramento de dois novos grupos que antes eram parte de outros: educação e comunicação.

\section{Tabela 1}

Peso médio no IPCA (em \%) dos segmentos resultantes do cruzamento da classificação por tipo de precificação com os grupos do IPCA

\begin{tabular}{c|l|c|c|c|c|c|c|c|c}
\cline { 3 - 10 } \multicolumn{2}{c}{} & \multicolumn{4}{c}{$2000-2005$} & \multicolumn{4}{c|}{$2006-2009$} \\
\cline { 2 - 10 } \multicolumn{2}{c}{} & Total & C & NC & M & Total & C & NC & M \\
\hline 1 & Alimentação e bebidas & 22,6 & 14,44 & 8,20 & - & 21,7 & 12,13 & 9,61 & - \\
\hline 2 & Habitação & 16,3 & 1,36 & 6,43 & 8,48 & 13,7 & 1,08 & 5,93 & 6,74 \\
\hline 3 & Artigos de residência & 5,7 & 5,24 & 0,42 & - & 4,5 & 4,12 & 0,42 & - \\
\hline 4 & Vestuário & 5,3 & 5,32 & - & - & 6,4 & 6,41 & - & - \\
\hline 5 & Transportes & 21,6 & 4,24 & 4,56 & 12,84 & 20,4 & 4,51 & 3,85 & 12,08 \\
\hline 6 & Saúde e cuidados pessoais & 10,7 & 6,32 & 1,82 & 2,54 & 10,8 & 2,70 & 1,75 & 6,32 \\
\hline 7 & Despesas pessoais & 9,3 & 2,48 & 6,45 & 0,37 & 9,7 & 2,22 & 7,06 & 0,41 \\
\hline 8 & Educação & 4,8 & 0,20 & 4,65 & - & 6,8 & 0,26 & 6,57 & - \\
\hline 9 & Comunicação & 3,6 & 0,02 & 0,02 & 3,58 & 5,9 & 0,31 & 0,45 & 5,10 \\
\hline & Total (IPCA) & 100 & 39,6 & 32,6 & 27,8 & 100 & 33,7 & 35,6 & 30,6 \\
\hline
\end{tabular}

Fontes: IBGE e BCB. Elaboração própria.

Os pesos médios dos 22 segmentos no IPCA são apresentados na Tabela 1 para os períodos 2000-2005 e 2006-2010 . Mesmo nos intervalos das atualizações da estrutura de pesos de acordo com as novas versões da POF, os pesos dos subitens sofrem pequenos ajustes a cada mês porque o IPCA é calculado pelo método de Laspeyres ${ }^{6}$. As linhas mostram os nove grupos do IPCA e as colunas C,

(4) Acima do nível de subitem as mudanças ocorridas em julho de 2006 foram a exclusão do item 1117. Alimentos prontos, cujos subitens provavelmente foram agregados a outros do item 1201. Alimentação fora do domicílio, e a transformação do subitem 8101014. Cursos diversos no item 8104. Cursos diversos, com a especificação de alguns cursos em subitens. Não houve mudanças nos níveis de grupo e subgrupo. Vale mencionar que no mesmo ano de 2006 a classificação do BCB por tipo de precificação foi alterada duas vezes: em janeiro, o subitem álcool combustível passou da categoria monitorado para comercializável e todos os subitens que compõem o item produtos farmacêuticos foram reclassificados de comercializáveis para monitorados; em julho foram feitas adaptações para acompanhar as alterações do IBGE.

(5) $\mathrm{O}$ cruzamento resultou em 22 séries, ao invés de 27 , porque alguns grupos não têm subitens classificados sob uma ou duas modalidades específicas de precificação. Na tabela, esses casos são identificados pelas células com um traço.

(6) Como o IPCA é um número-índice do tipo Laspeyres, é calculado considerando que as quantidades da cesta de consumo são fixas na proporção estabelecida em cada revisão da cesta de consumo. A POF, que fornece a cesta de consumo do IPCA, informa o gasto com cada produto, de maneira que as quantidades são estimadas dividindo o valor gasto no produto pelo seu preço. Como a taxa de variação de preços de cada produto não é igual à inflação medida no agregado, a cada mês os pesos dos produtos são corrigidos para preservar a hipótese de quantidades fixas. Para mais informações, ver IBGE (2007). 
NC e M - comercializáveis, não comercializáveis e monitorados, respectivamente - a classificação por tipo de precificação. As colunas com o rótulo Total indicam o peso médio do respectivo grupo no IPCA e a última linha aponta os pesos no IPCA da classificação por tipo de precificação.

\section{2 Índice de pressão sobre a meta de inflação}

O regime de metas para a inflação no Brasil completou dez anos de duração em junho de 2009. Ao longo da década, os componentes do IPCA sofreram mudanças de comportamento e apresentaram dinâmicas específicas. $\mathrm{O}$ gráfico 1 mostra as séries acumuladas em 12 meses da inflação pelo IPCA e da inflação dos bens comercializáveis, não comercializáveis e monitorados, de julho de 2000 a dezembro de 2009.

\section{Gráfico 1}

Inflação acumulada em 12 meses do IPCA e dos bens comercializáveis, não comercializáveis e monitorados - julho de 2000 a dezembro de 2009

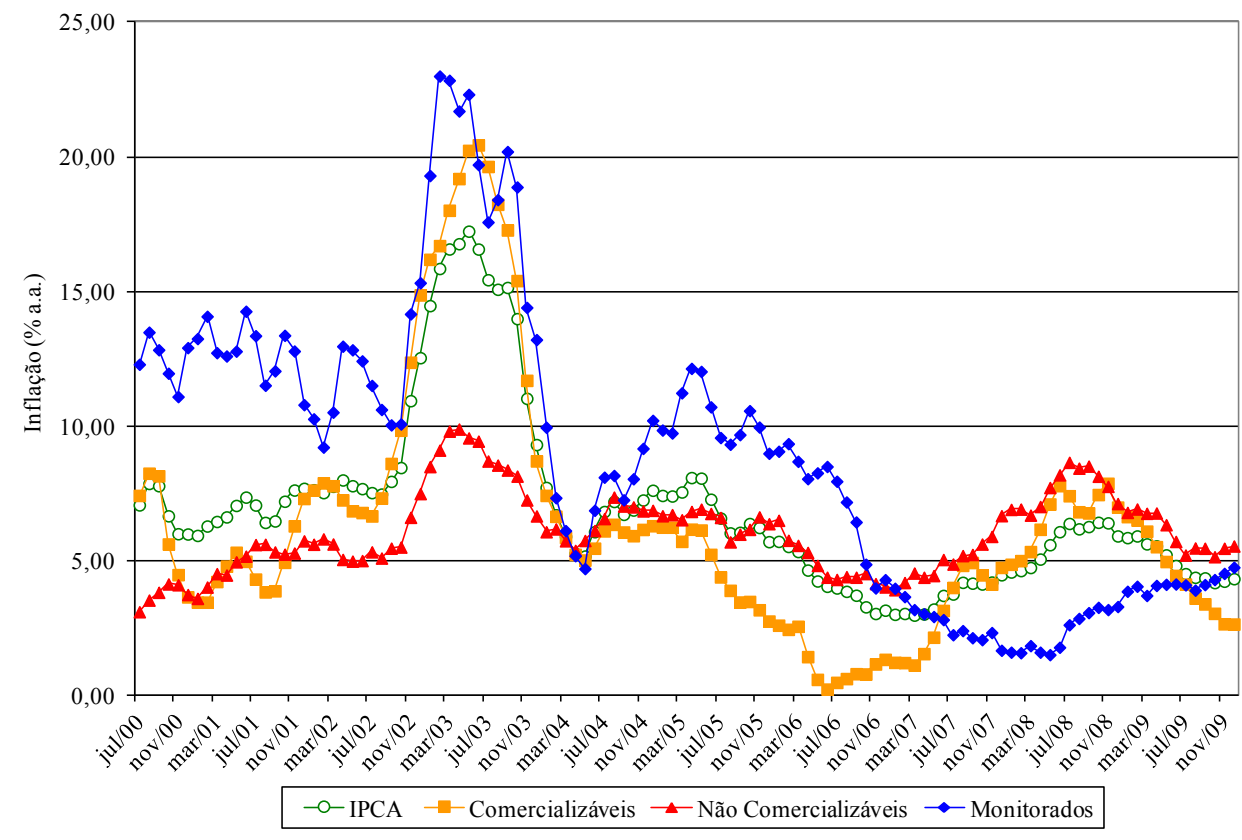

Fontes: IBGE e BCB. Elaboração própria.

Pela observação direta do gráfico, é possível apontar, grosso modo, quatro fases diferentes. Até o terceiro trimestre de 2002, a inflação dos monitorados é muito superior à dos comercializáveis e não comercializáveis e à própria meta de inflação. O período do quarto trimestre de 2002 ao início de 2004 é marcado pela intensa depreciação cambial relacionada às incertezas do mercado financeiro com 
as eleições presidenciais e pelo ajuste da inflação de volta a um patamar mais baixo no início do governo Lula. Nesses meses, embora a inflação em geral tenha se elevado, foi mais intensa nos monitorados e nos comercializáveis, que determinaram o comportamento do IPCA. Do início de 2004 ao final de 2006, os monitorados ainda são os bens que mais pressionam a inflação para cima, enquanto os comercializáveis pressionam fortemente para baixo e os não comercializáveis permanecem na mesma tendência do IPCA. Por fim, de 2007 até o final de 2009, a inflação dos monitorados pressiona para baixo o IPCA e as maiores pressões inflacionárias vêm dos não comercializáveis.

Uma análise mais detalhada da dinâmica da inflação no período pode ser obtida desagregando mais as séries, porém isso traz maiores dificuldades para organizar as informações. Para mensurar com maior acuidade quais foram os bens mais importantes para determinar a tendência do IPCA, é necessário considerar tanto o peso do bem quanto a magnitude da variação de seu preço. É de se esperar que os grupos de preços com peso maior no IPCA sejam mais influentes na determinação da tendência do índice todo. Contudo, a magnitude dos aumentos de preços dos bens também responde por sua influência na evolução do índice todo.

Por exemplo, em 2009 o grupo transportes teve um peso médio de 19,4\% no IPCA, enquanto para o grupo despesas pessoais esse peso foi de 10,1\%. Mas, apesar de seu peso menor, o grupo despesas pessoais causou maior impacto na trajetória do IPCA, pois teve inflação de $8,03 \%$, bem superior à inflação de $2,36 \%$ dos transportes. $\mathrm{O}$ oposto também é válido, ou seja, um agrupamento de bens pode ter inflação alta, mas pouco afetar o IPCA se tiver um peso muito baixo.

A fim de apresentar de forma sintética quais foram os segmentos mais influentes na inflação como um todo, criou-se um índice que considera tanto o peso quanto a magnitude da inflação, denominado Índice de Pressão sobre a Meta de Inflação (IPMI).

O IPMI foi construído com o objetivo de ordenar os bens ou agrupamentos de bens - pode ser calculado para qualquer nível de agregação - que mais influenciaram a trajetória do IPCA a cada período especificado, apontando também a magnitude do impacto no índice geral. Levam-se em consideração o peso e a inflação específica do bem no período.

O índice mede, para cada bem ou agrupamento de bens, o impacto no IPCA em termos de desvio - em pontos percentuais (p.p.) - do centro da meta de inflação anunciada pelo BCB para o período. Tome-se por conveniência o período de um ano e a desagregação de subitem, o menor nível do IPCA. O IPMI mostra 
em quantos pontos cada bem empurrou a inflação pelo IPCA para cima ou para baixo do centro da meta.

A ideia do índice consiste em calcular, para cada mês, o quanto a inflação do bem se desviou do centro da meta da inflação do IPCA convertida para uma escala mensal e, a seguir, acumular nos 12 meses, ponderando cada mês pelo peso mensal do bem. A fórmula de cálculo é:

$$
I P M I_{i}=100 \times\left(\prod_{j=1}^{12}\left(1+p_{i j}\left(\pi_{i j}-m_{j}\right)\right)-1\right)
$$

onde $I P M I_{i}$ é o Índice de Pressão sobre a Meta de Inflação para o bem $i$ no ano considerado; $p_{i j}$ é o peso do bem $i$ no mês $j$; $\pi_{i j}$ é a inflação do bem $i$ no mês $j$; e $m_{j}$ é o centro da meta de inflação convertido para uma escala mensal, que é simplesmente a taxa de variação mensal que, acumulada em 12 meses, resulta no centro da meta anual ${ }^{7}$.

Seria desejável que a soma dos índices calculados para cada bem igualasse exatamente o desvio da inflação pelo IPCA em relação ao centro da meta no ano. Contudo, isso não ocorre porque o peso dos subitens muda a cada mês. Mas o IPMI tem a propriedade de chegar muito próximo ao desvio do IPCA em relação ao centro da meta nos anos considerados. Por exemplo, os desvios efetivos da meta de 4,5\% nos anos de 2007, 2008 e 2009 foram em p.p., respectivamente: $-0,043 \%$, $+1,39 \%$ e $-0,17 \%$, enquanto os desvios computados pelo índice de pressão foram, respectivamente: $-0,04 \%,+1,33 \%$ e $-0,16 \%$. Cabe destacar que o método utilizado é muito mais preciso que a alternativa de simplesmente tomar a média dos pesos no ano e a inflação acumulada para cada bem, cujos resultados são bastante distantes do desvio da meta efetivamente observado.

\subsection{Decomposição do IPCA sob o regime de metas para a inflação}

Nesta seção, faz-se uma análise descritiva da inflação brasileira sob os dez anos do regime de metas, aplicando o IPMI ao IPCA classificado por segmentos. A Tabela 2 mostra o IPMI calculado para os 22 segmentos de 2000 a 2005. Os resultados de cada ano estão divididos em três blocos. No primeiro, constam a inflação do ano pelo IPCA, o IPCA recalculado a partir da inflação por subitens disponibilizada no site do IBGE, o centro da meta de inflação, o desvio do centro da meta e o erro do índice, que é a diferença entre o desvio calculado pelo IPMI e o

(7) Por exemplo, para a taxa de $4,5 \%$ como centro da meta anual de inflação, a taxa mensal equivalente é de aproximadamente $0,367 \%$. 
desvio efetivamente observado, ambos computados em relação ao IPCA recalculado $^{8}$. No segundo bloco, estão os segmentos que tiveram inflação acima do centro da meta, enquanto, no terceiro, bloco estão os segmentos com inflação abaixo do centro da meta.

A coluna IP indica o valor do IPMI, marcando em p.p. o quanto o segmento em questão pressionou a inflação do IPCA para cima ou para baixo do centro da meta ${ }^{9}$. A coluna IP \% mostra, como percentual, a razão entre o índice de pressão e o subtotal (acima ou abaixo da meta), ou seja, o quanto aquele segmento explica da pressão para cima ou para baixo do centro da meta no ano - a soma dos valores na coluna é igual a $100 \%$. As colunas infl e peso trazem, respectivamente, a inflação acumulada no ano e o peso médio no ano. Os segmentos estão ordenados pelo valor do índice de pressão.

Ao longo desses cinco anos, nota-se que os preços dos bens monitorados foram os que mais pressionaram a inflação, especialmente os segmentos transportes monitorados, habitação monitorados e comunicação monitorados. Em 2000, foram os três segmentos que mais pressionaram a inflação, em 1,69 p.p. acima do centro da meta. Em 2001 e 2002, habitação monitorados e transportes monitorados foram, respectivamente, o segundo e o terceiro segmentos que mais pressionaram a inflação, com 1,59 p.p. em 2001 e 2,66 p.p. em 2002. Os três segmentos estiveram entre os quatro que mais pressionaram a inflação para cima nos anos de 2003 e 2004, respectivamente em 1,13 p.p. e 1,17 p.p. Já em 2005, transportes monitorados e habitação monitorados foram os dois segmentos de maior pressão inflacionária, com IPMI acumulado de 1,01 p.p.

(8) Quanto ao IPCA recalculado a partir dos subitens, observou-se que as diferenças em relação ao IPCA reportado pelo IBGE surgem já no nível de agregação imediatamente superior, por item, mas são muito pequenas para a maioria dos itens e dos anos. Essas pequenas diferenças existem porque o IBGE - seguindo recomendações de organismos internacionais de estatísticas oficiais - reporta em seu site a decomposição do IPCA por subitens com duas casas decimais, mas utiliza um nível maior de precisão para calcular o IPCA agregado. Contudo, tais diferenças de arredondamento não explicam a considerável divergência de 2000 a 2006 entre o IPCA reportado pelo IBGE e o recalculado. Refazendo a agregação, pôde-se perceber que tal divergência se deve a três itens 1103. Tubérculos, raízes e legumes, 1105. Hortaliças e verduras e 1106. Frutas - cuja taxa de variação de preços recalculada a partir dos subitens é muito diferente da reportada pelo IBGE. Isso ocorre porque até 2006 esses itens eram calculados por uma metodologia diferente daquela empregada nos demais itens devido à sua elevada sazonalidade, que implica substituição de produtos ao longo do ano (por exemplo, há frutas consumidas em março que desaparecem da cesta de consumo em setembro). Utilizava-se para os subitens sazonais desses três itens a fórmula de Paasche com pesos mensais, que por ter outros problemas foi substituída na revisão de 2006 pela fórmula de Laspeyres com pesos anuais, a mesma utilizada nos outros itens. Para mais detalhes, ver IBGE (2005). Agradecemos a Gustavo Leite, da Coordenação de Índices de Preços do IBGE, pelo esclarecimento desses pontos. Nesse texto, optou-se por padronizar o IPCA recalculado com a mesma metodologia para todos os subitens, uma soma ponderada pelos pesos reportados pelo IBGE, para manter a coerência com o Índice de Pressão sobre a Meta de Inflação.

(9) Para os anos de 2003 e 2004, foram consideradas a metas redefinidas no início de 2003 após o choque cambial de 2002. 


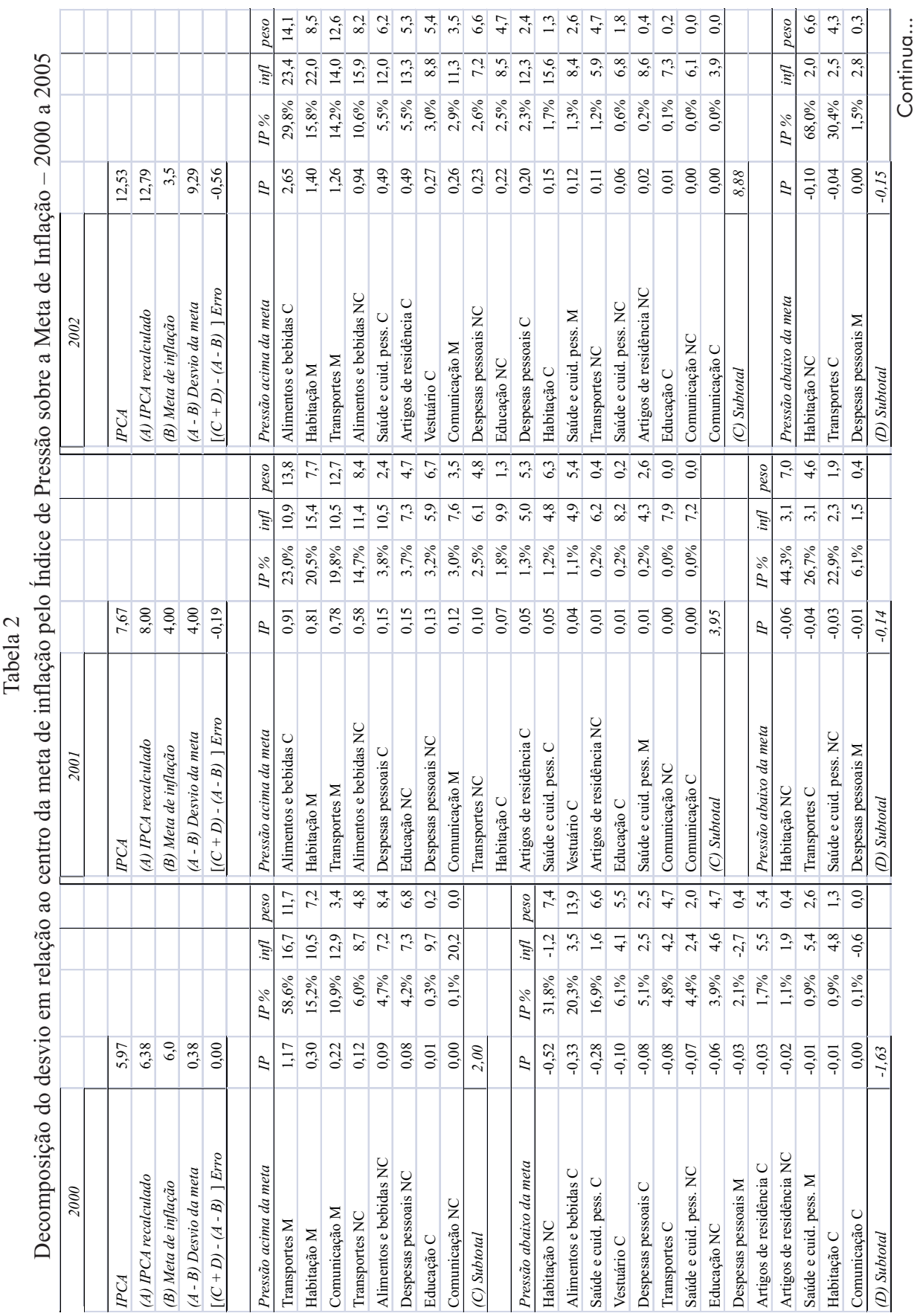




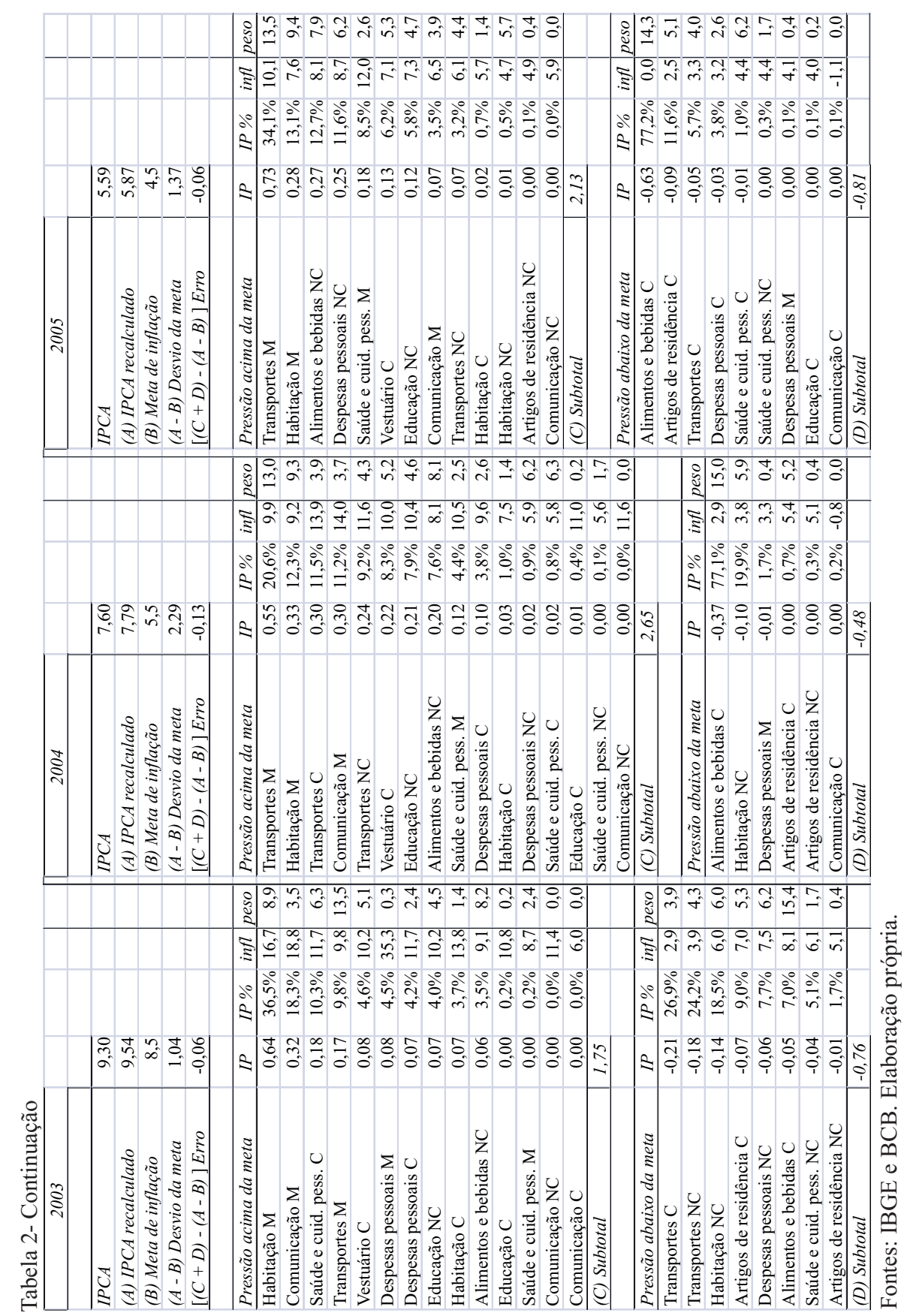


A Tabela 3 decompõe a inflação dos monitorados por subitem e está dividida em dois blocos: de 2000 a 2005 e de 2006 a 2009. Dentro de cada segmento, os subitens estão ordenados pelo peso médio no período 2000-2005, a segunda coluna da tabela. A terceira coluna da tabela mostra a soma dos IPMIs dos anos de 2000 a 2005. Essas duas colunas são repetidas para o bloco dos anos 2006 a 2009.

Tabela 3

Decomposição em subitens do Índice de Pressão sobre a Meta de Inflação dos bens monitorados 2000 a 2009

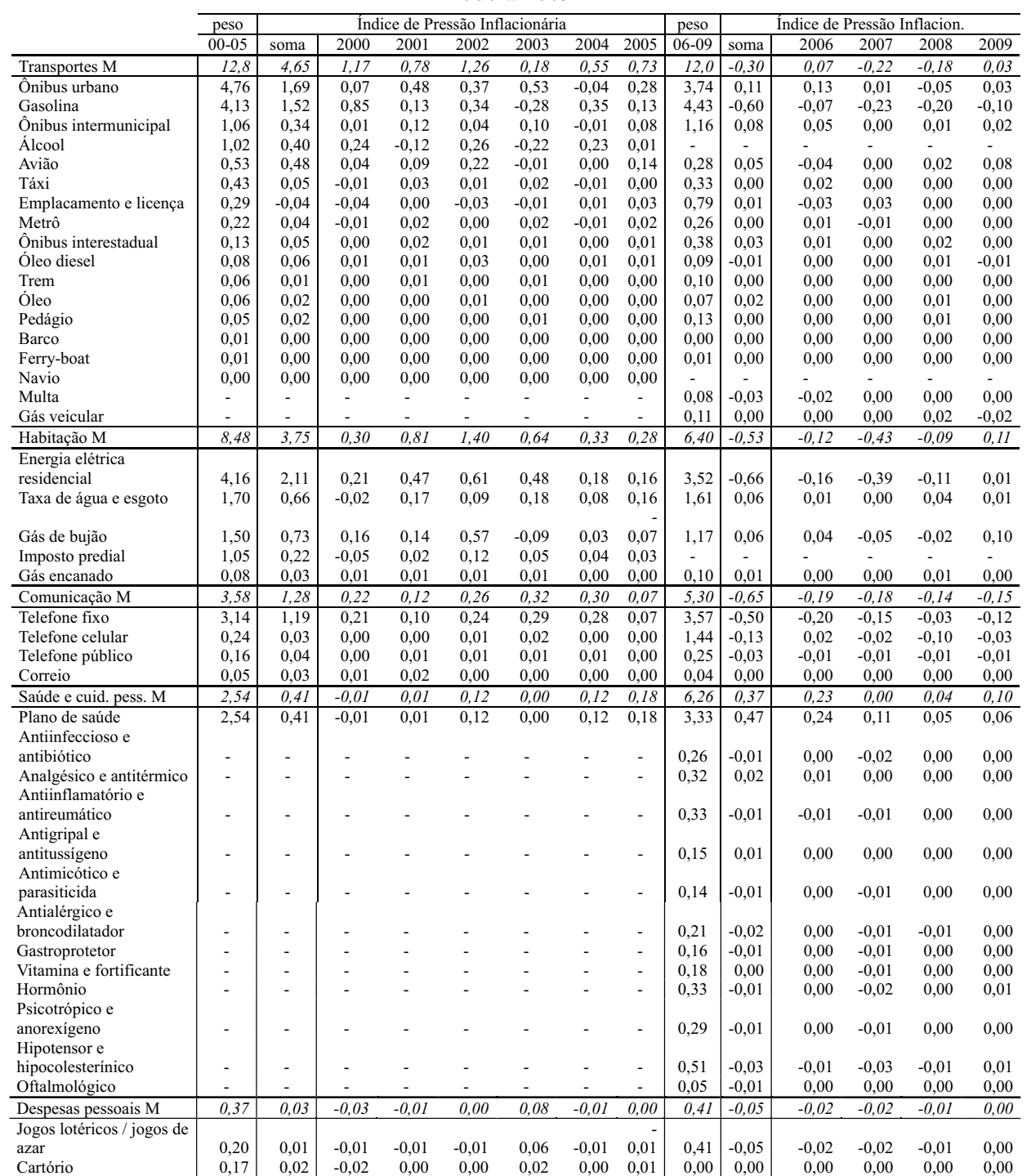

Fontes: IBGE e BCB. Elaboração própria. 
Quanto aos anos de 2000 a 2005, em transportes monitorados os subitens mais importantes são: ônibus urbano, que só não teve grande impacto na inflação em 2000 e 2004, anos de eleições municipais; gasolina, com elevada pressão para cima da meta em 2000, 2002 e 2004 e para baixo da meta em 2003; álcool, que também pressionou para cima em 2000, 2002 e 2004, mas pressionou para baixo em 2001 e 2003; avião, com pressão de alta considerável em 2002 e 2005; e ônibus intermunicipal, cuja pressão foi distribuída ao longo dos anos, com destaque para 2001,2003 e 2005.

No segmento habitação monitorados, o subitem mais importante é energia elétrica residencial, que exerceu forte impacto de elevação no IPCA em todos esses seis anos, embora com intensidade um pouco menor em 2004 e 2005 . O subitem gás de bujão teve uma pressão de alta considerável nos três primeiros anos da amostra, assim como o subitem taxa de água e esgoto o fez nos anos de 2001, 2003 e 2005. O subitem imposto predial teve sua pressão distribuída ao longo dos anos, com destaque para 2002.

Já o segmento comunicação monitorados tem seu comportamento dominado pelo subitem telefone fixo, cuja pressão inflacionária foi forte em 2000 e de 2002 a 2004, embora nos anos de 2001 e 2005 o IPMI também tivesse sido considerável. O subitem plano de saúde era o único do segmento saúde e cuidados pessoais monitorados até 2005 e exerceu pressão acima de 0,1 p.p., mas abaixo de 0,2 p.p. nos anos 2002, 2004 e 2005. Os subitens de despesas pessoais monitorados só tiveram inflação muito elevada em 2003, mas, por seu baixo peso no IPCA, o impacto foi pequeno.

Além dos monitorados, alguns outros segmentos se destacam no período, como os pertencentes ao grupo alimentos e bebidas. O segmento alimentos e bebidas não comercializáveis exerce pressão sistemática de alta sobre a inflação, principalmente nos anos de 2001, 2002, 2004 e 2005. Seus principais componentes são a alimentação fora do domicílio, feijão, vegetais (legumes, raízes, verduras, frutas etc.), pescados e ovos. Já o segmento alimentos e bebidas comercializáveis tem um comportamento mais errático, mas em quase todos os anos está entre os segmentos que mais pressionam a inflação para baixo, como em 2000, 2004 e 2005, ou para cima, como em 2001 e 2002. Seus componentes mais importantes são o arroz, carnes em geral, massas, açúcares e derivados, leites e derivados, panificados, bebidas e enlatados ${ }^{10}$.

(10) Deve-se apontar uma mudança de classificação do frango em pedaços. De agosto de 1999 a julho de 2006, era composto por três subitens no IPCA - 1110011. Peito de frango, 1110012. Coxa de frango e 1110014 Asa de frango -, classificados pelo BCB como não comercializáveis. A partir de agosto de 2006, foram agrupados no subitem 1110010. Frango em pedaços, classificado como comercializável pelo BCB. 
Outro segmento de destaque é habitação não comercializáveis, cujo principal segmento é aluguel residencial. De 2000 a 2004 o segmento pressiona para baixo, com inflação substancialmente inferior ao centro da meta, enquanto em 2005 a inflação esteve apenas ligeiramente acima do centro da meta.

A Tabela 4 apresenta o índice de pressão calculado para os 22 segmentos de 2006 a 2009 e sua construção é idêntica à da Tabela 2. A decomposição da inflação para o ano de 2006 é atípica em comparação aos anos anteriores e posteriores, pois desde a adoção do regime de metas foi o único ano em que a inflação esteve bastante abaixo do centro da meta. Nesse ano, apenas os segmentos saúde e cuidados pessoais monitorados e despesas pessoais não comercializáveis exerceram pressão considerável acima da meta.

A partir de 2007, fica mais clara uma mudança estrutural na composição da inflação. Três segmentos passam a ser os mais relevantes em determinar a tendência do IPCA - alimentos e bebidas comercializáveis, alimentos e bebidas não comercializáveis e despesas pessoais não comercializáveis - e os preços monitorados - especialmente transportes monitorados, habitação monitorados e comunicação monitorados - deixam de pressionar fortemente o IPCA para cima e na maior parte dos anos exercem pressão para baixo do centro da meta.

Essa transformação no comportamento dos preços monitorados pode ser vista com mais detalhe no segundo bloco da Tabela 3. No segmento transportes monitorados, os subitens que pressionavam bastante a inflação para cima passaram em geral a ter uma tendência mais próxima do centro da meta. Essa é a situação de ônibus urbano, ônibus intermunicipal e avião. Houve uma reversão no caso do subitem gasolina, que pressionava muito a inflação para cima no período anterior e passou a pressionar sistematicamente para baixo da meta. Um subitem importante até então, álcool, foi reclassificado pelo BCB como comercializável a partir de 2006. O subitem navio foi retirado do IPCA e os subitens multa e gás veicular foram adicionados.

Como expõe Fernandez Silva (2007), as regras para reajustes de preços de transportes públicos em geral são controversas. Tomando como exemplo o ônibus urbano, que tem o maior peso entre os transportes públicos, cada município segue seus próprios critérios, frequentemente pouco transparentes. Em 95\% dos municípios com mais de 300 mil habitantes, a referência principal para reajuste tarifário é o cálculo por meio de planilhas de custos, mas é comum a interferência de motivações políticas. Ademais, há um problema grave de assimetria de informações entre os concessionários e o poder público. Não é claro o porquê da inflação menor nos transportes públicos a partir de 2006, mas um possível motivo importante é o impacto nos custos da inflação mais baixa dos combustíveis. 


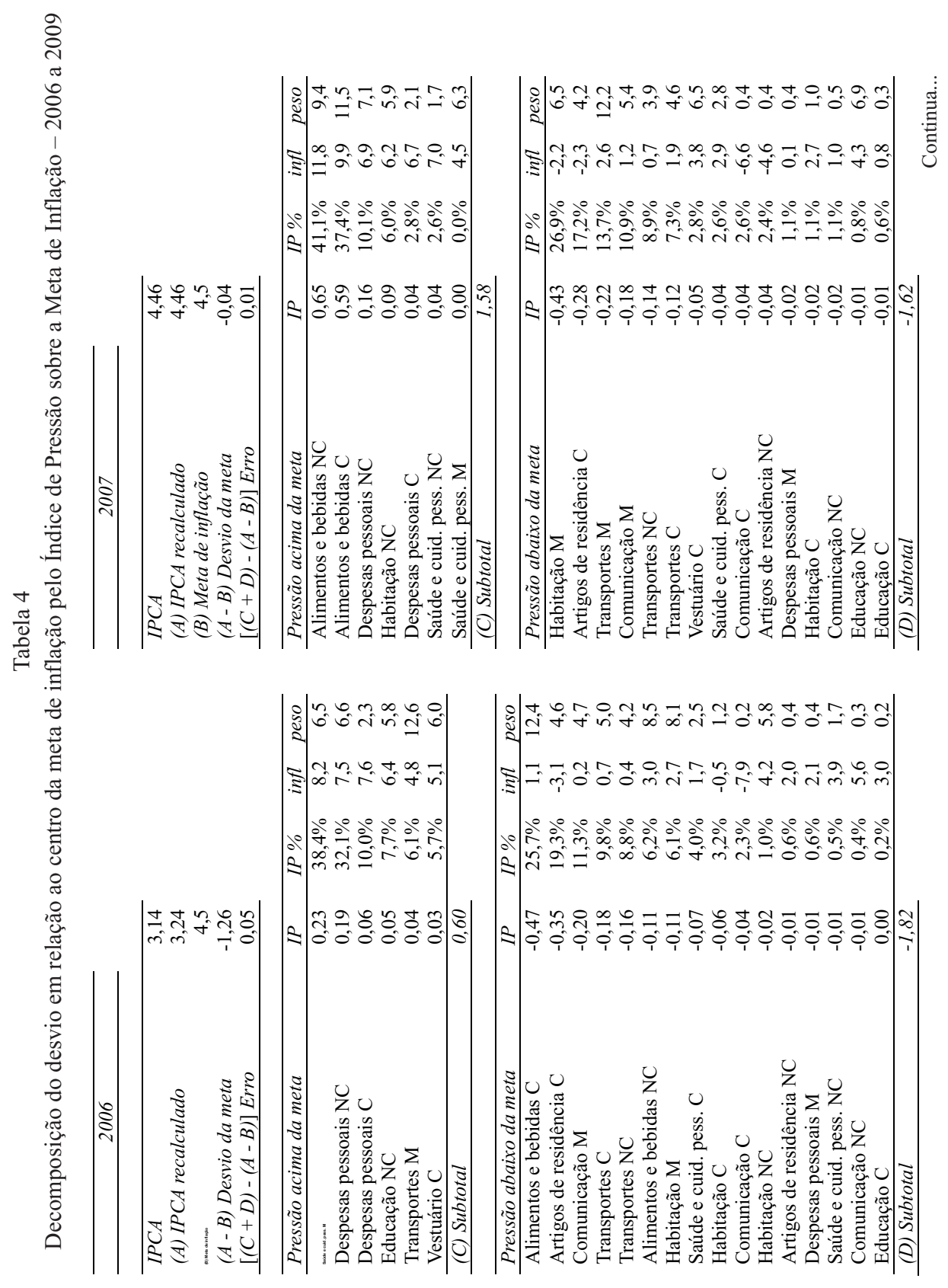



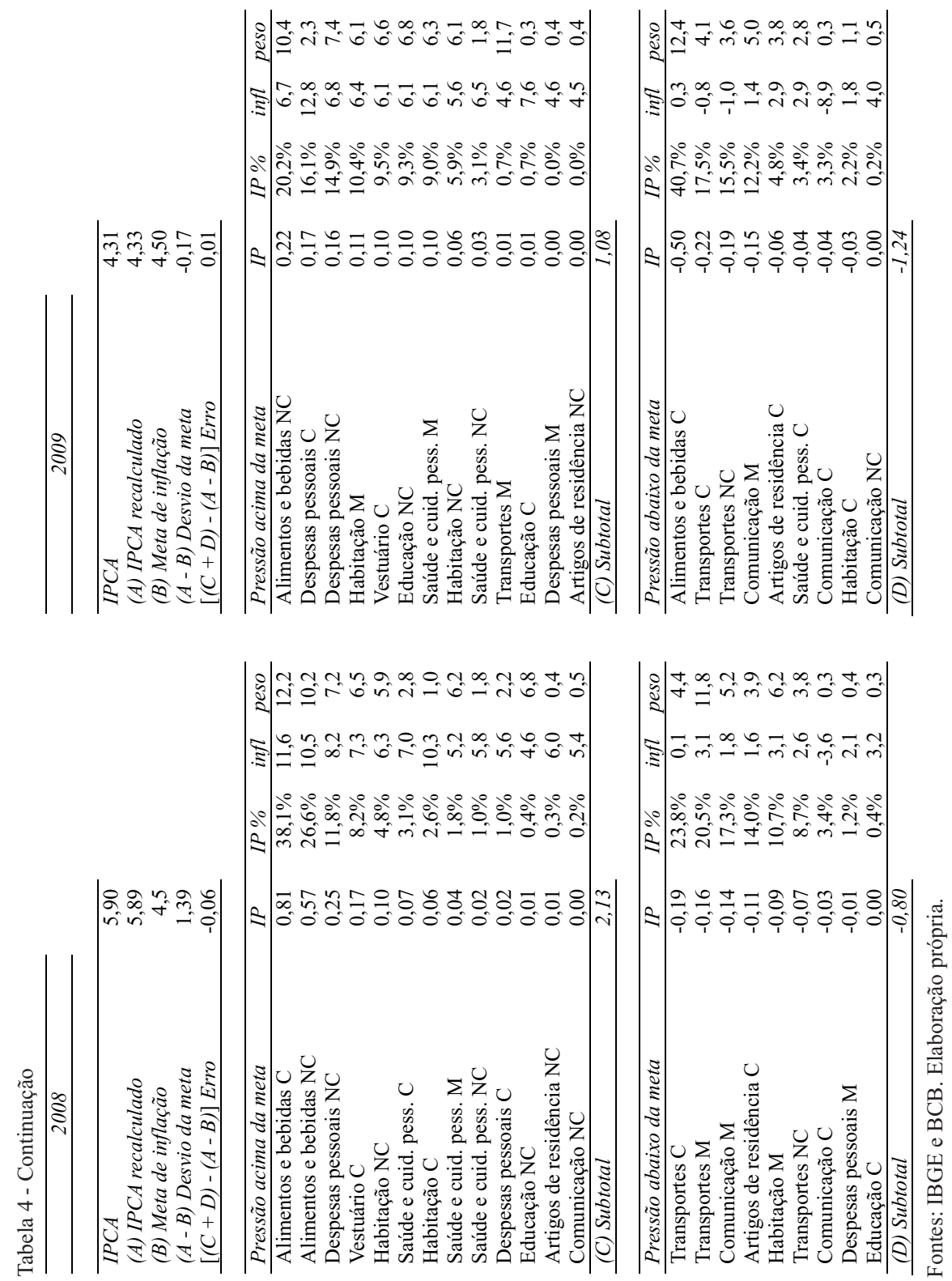
Quanto à inflação da gasolina, de acordo com Rocha de Sousa (2007), a Petrobras, desde o final de 2002, vem adotando intervalos mais longos de repasse de preços internacionais para derivados de petróleo. Ainda assim, é provável que a queda do nível da inflação da gasolina e de sua volatilidade - relacionada à redução da variância da inflação que foi constatada no modelo econométrico para todo o segmento, como será visto na subseção 3.3 - possa em grande parte ser atribuída à política adotada pelo Ministério da Fazenda após 2006 de reduzir temporariamente a tributação sobre gasolina e óleo diesel durante picos de preços do petróleo no mercado internacional (Barbosa; Pereira de Souza, 2010).

O modelo testado para o segmento habitação monitorados, que será apresentado na terceira seção do artigo, identificou uma quebra estrutural com redução do nível e da volatilidade da inflação em 2006. Como mostra a Tabela 3, o subitem energia elétrica residencial foi o maior responsável por essa mudança, pois até 2005 exerceu sistematicamente forte pressão acima da meta e a partir de então passou a ser o subitem que mais pressionou a inflação para baixo dentre os monitorados. Duas mudanças na regulação do setor, apontadas por Rocha de Sousa (2007), podem esclarecer esse fato. Primeiro, o antigo marco regulatório permitia que as distribuidoras repassassem às suas tarifas custos de energia termelétrica comprada de empresas a elas associadas, mais cara que a energia hidrelétrica disponível no mercado. Com a nova lei do setor elétrico de 2004, o valor para repasse dos custos de aquisição de energia passa a ser definido pela Agência Nacional de Energia Elétrica (Aneel) com base no preço médio dos leilões de compra de energia elétrica. Em segundo, para leilões de energia nova, realizados a partir de dezembro de 2004, o IPCA passou a ser adotado como indexador ao invés do Índice Geral de Preços - Mercado (IGP-M), da Fundação Getulio Vargas (FGV). A inflação do setor ainda foi alta em 2005 devido à incorporação de componentes financeiros diversos no reajuste, como a compensação de perdas pelo racionamento de energia de 2001 e 2002.

Por fim, o segmento comunicação monitorados, que entre 2000 e 2004 pressionou o IPCA fortemente para cima, já a partir de 2005 teve uma inflação mais próxima do centro da meta e a partir de 2006 passou a pressionar sistematicamente para baixo do centro da meta. No modelo econométrico, a mudança estrutural na inflação do segmento apareceu por meio da redução da magnitude das funções de transferência de impulso, o que significa que diminuiu a sensibilidade dos preços a choques diversos. Como fica claro pela Tabela 3, a dinâmica do segmento coincide com a do subitem telefone fixo. Segundo Mattos (2007), os contratos, adotados em 1999, durante a privatização do setor, venceram em 2005 e os novos contratos vigentes a partir de 2006 trouxeram alterações no processo de revisão de tarifas. O Índice Geral de Preços-Disponibilidade Interna (IGP-DI) foi substituído por um novo índice como indexador, o Índice de 
Atualização de Tarifas (IST), que reflete custos do setor de telefonia. Isso explica a modificação da função de transferência de impulso, já que o IGP-DI é muito sensível a choques externos. Ademais, o cálculo dos ganhos de produtividade para repasse às tarifas foi aprimorado: passou a ser pós-fixado - antes era fixado previamente, em valores inferiores aos observados a posteriori - e calculado pelo mínimo entre seu próprio ganho de produtividade e a média das operadoras, o que incentiva a concorrência por ganhos de eficiência. Embora com um impacto menor, cabe destacar ainda o subitem telefone celular, cujo peso médio aumentou bastante ao longo da década e que pressionou a inflação para baixo, em virtude da elevada concorrência no setor.

Com a mudança estrutural nos preços monitorados, outros segmentos passaram a ter mais destaque na decomposição do IPCA. Os dois segmentos do grupo alimentos e bebidas, comercializáveis e não comercializáveis, na verdade, mantiveram o mesmo comportamento observado nos anos anteriores. Até 2006, o segmento alimentos e bebidas não comercializáveis foi, depois dos monitorados, o que mais pressionou a inflação para cima de forma sistemática. Em 2006, o segmento exerceu pressão para baixo do centro da meta, mas, de 2007 a 2009, retomou a tendência anterior com mais força e, no saldo do período, foi o segmento que mais empurrou a inflação para cima. O segmento alimentos e bebidas comercializáveis, que de 2000 a 2005 foi em alguns anos o que mais afetou para cima os preços e em outros o que mais pressionou a inflação para baixo, também manteve seu comportamento. Em 2006 e 2009, foi o que mais empurrou o IPCA para baixo, enquanto em 2007 e 2008 esteve entre os dois que mais pressionaram para cima.

O segmento despesas pessoais não comercializáveis foi o terceiro que mais pressionou a inflação para cima da meta após 2006. Já no período entre 2000 e 2005, a inflação do segmento esteve acima do centro da meta em quase todos os anos, com exceção de 2003. Mas, a partir de 2005, nota-se que o segmento passou a pressionar a inflação com maior intensidade. $\mathrm{O}$ subitem mais relevante desse segmento é empregado doméstico, cujo peso no IPCA (3,08\% em média entre 2006 e 2009) é o maior do segmento (média de 7,13\%). Embora outros subitens do segmento despesas pessoais não comercializáveis também tivessem inflação alta no período, a inflação de empregado doméstico foi uma das mais altas, de maneira que a pressão inflacionária do segmento segue a tendência do subitem: o IPMI de empregado doméstico nos cinco anos de 2005 a 2009 foi igual a, respectivamente, 0,20 p.p., 0,17 p.p., 0,14 p.p., 0,19 p.p. e 0,13 p.p., enquanto o IPMI de despesas pessoais não comercializáveis foi nesse período igual a 0,25 p.p., 0,21 p.p., 0,16 p.p., 0,25 p.p. e 0,16 p.p. 


\section{Determinantes da inflação por segmentos}

\subsection{Variáveis explicativas}

Para estimar os determinantes da inflação nos segmentos, foram testadas quatro variáveis macroeconômicas: variação cambial, variação dos preços das commodities, demanda e expectativas de inflação. Ademais, também foram considerados dois outros aspectos potenciais causadores de inflação, inércia e um componente estrutural.

A variação cambial afeta a inflação através dos custos de produção, dos preços dos bens finais importados e dos preços dos bens comercializáveis. Nas estimações, foi utilizada a variação percentual da taxa de câmbio R \$/US\$ obtida na base de dados do BCB (2010). A variação dos preços das commodities reflete cotações para mercadorias cuja formação de preços se dá internacionalmente, impactando a inflação via mudança nos preços relativos. Esta variável pode ser também uma proxy para medir o efeito do (des)aquecimento da economia mundial nos preços domésticos. A série utilizada foi o índice total dos preços das commodities disponibilizada pelo Ipeadata $(2010)^{11}$.

O excesso ou escassez de demanda é um importante aspecto para determinação da taxa de inflação, sendo usual a utilização dessa variável nos modelos. Trata-se de uma tentativa de identificar de que modo o ciclo econômico afeta a inflação. Dessa forma, foi estimado um filtro Hodrick-Prescott (HP) para o logaritmo do PIB mensal em valores correntes (série divulgada pelo BCB) deflacionado pelo IGP-DI. A proxy para o excesso ou escassez de demanda agregada foi obtida pela diferença entre o PIB mensal deflacionado e a tendência HP. Por conta das características específicas da pesquisa, que pretende analisar os componentes desagregados do IPCA em setores diversos, optou-se por não adotar o índice da produção industrial ou o Nível de Utilização da Capacidade Instalada da Indústria (Nuci), que são variáveis comumente colocadas na literatura como proxies para pressões de demanda agregada.

A expectativa em relação à inflação futura pode ter impacto sobre a inflação presente, na medida em que os agentes antecipem os movimentos dos preços tentando evitar perdas decorrentes da mudança nos preços relativos. A proxy utilizada foi a série da média mensal da variação das expectativas para a

(11) Esse índice é feito utilizando-se dados mensais dos preços de diversos produtos calculados em dólares e disponibilizados pelo Fundo Monetário Internacional (FMI). Em seguida, é feita uma correspondência entre esses produtos e os produtos incluídos no Índice de Preços no Atacado (IPA) agregando-se alguns e eliminando-se outros que não possuam equivalentes. Definidos os produtos, os pesos do IPA foram normalizados de forma a somar 100. O índice construído é do tipo Laspeyres de base móvel com variações de preços sendo aplicadas sucessivamente sobre os pesos alterados do período anterior. Para mais detalhes, ver Nonennberg e Lameiras, 2005. 
inflação do IPCA cheio para 12 meses. Esta série é resultado da pesquisa semanal Focus, publicada pelo BCB. Pelo corte analítico deste trabalho foi possível incluir esta variável sem incorrer nos problemas comuns de endogeneidade. Isso decorre do nível de desagregação, pois, em tese, cada segmento específico do IPCA teria influência limitada na formação das expectativas para o IPCA total. Adicionalmente, testes de causalidade de Granger não apresentaram evidência de simultaneidade das expectativas com cada um dos segmentos.

A inércia inflacionária é um componente que representa o impacto da inflação passada do segmento (e não explicada pelos outros determinantes) na inflação presente do mesmo. Carneiro et al. (2002) e Schwartzman (2006) utilizam o IPCA total defasado argumentando que os contratos são indexados pela inflação cheia e não pela inflação de cada grupo. Por conta da forte multicolinearidade com a expectativa de inflação do Focus, que torna difícil a identificação do impacto de cada variável, não foi incluído o IPCA total defasado. Como será visto na apresentação da metodologia econométrica, nos modelos estimados a inércia corresponde à propagação dos choques não explicados sobre a inflação do próprio segmento.

O efeito dos preços das commodities, da demanda, das expectativas e da inércia sobre a inflação é bastante intuitivo. O componente estrutural, no entanto, não costuma ser apresentado na literatura. Do ponto de vista da estrutura matemática dos modelos estimados, o componente estrutural da inflação seria representado pela presença de constantes e/ou tendências determinísticas. Do ponto de vista econômico, pode ser interpretado como a parte da inflação derivada da estrutura dos mercados e de outros aspectos microeconômicos, por exemplo.

A amostra começa em agosto de 1999 para os modelos sem expectativa de inflação, em julho de 2001 para os demais e termina em dezembro de 2009 para todos. Para estimar a equação de determinantes de cada um dos 22 segmentos, utilizou-se a técnica da função de transferência. O detalhamento do modelo e seus resultados são apresentados nas próximas seções.

\subsection{O modelo econométrico}

A identificação dos determinantes da inflação, medida pelo IPCA desagregado, foi feita através de modelos de função de transferência. Em geral, essa metodologia é indicada para situações em que: as séries temporais utilizadas são estacionárias, não há relação de simultaneidade entre as variáveis ${ }^{12}$ e não há preocupação em testar restrições teóricas. A estrutura geral do modelo pode ser representada pela seguinte equação:

(12) Para testar a existência de simultaneidade foram realizados testes de causalidade de Granger. Os resultados não evidenciaram a existência de impactos isolados dos segmentos de preços nas variáveis exógenas. 
$y_{i t}=\beta t+\omega_{0}+\sum_{j=1}^{k} \omega_{j} y_{i, t-j}+\sum_{l=0}^{p} \varphi_{h p, l} h p_{t-l^{+}}$

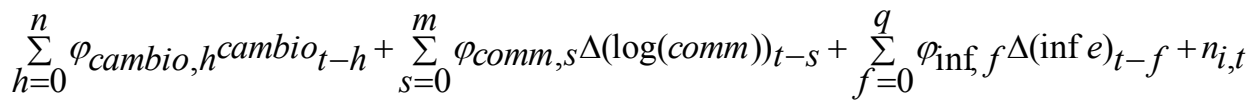

onde:

$t$ é uma tendência determinística;

$\omega_{0}$ é uma constante;

$y_{i t}$ é a inflação de um dado segmento do IPCA; e

$n_{i, t}$ é o resíduo que segue um processo Autoregressive Moving-Average (ARMA).

A forma reduzida do modelo é:

$$
\begin{aligned}
& y_{i t}=\frac{\beta t}{\Omega(L)}+\frac{\omega_{0}}{\Omega(L)}+\frac{\Gamma_{h p}(L)}{\Omega(L)} h p_{t-b h p}+\frac{\Gamma_{\text {cambio }}(L)}{\Omega(L)} \text { cambio }_{t-\text { bcambio }}+ \\
& \frac{\Gamma_{\text {comm }}(L)}{\Omega(L)} \Delta(\log (\text { comm }))_{t-b c o m m}+\frac{\Gamma_{\text {inf } e}(L)}{\Omega(L)} \Delta(\inf e)_{t-b \inf e}+\frac{\Phi(L)}{\Omega(L) \Theta(L)} \varepsilon_{i, t}
\end{aligned}
$$

onde:

$\Omega(L)=1-\omega_{1} L-\omega_{2} L^{2}-\omega_{3} L^{3} \ldots-\omega_{k} L^{k}$ é o polinômio relacionado à variável endógena;

$\Gamma_{x}(L)=\varphi_{x} L^{b}+\varphi_{x, 1} L^{b-1}+\varphi_{x, 2} L^{b-2}+\ldots+\varphi_{x, z} L^{z}-^{b}$ sendo $\Gamma_{x}(L)$ o polinômio relacionado à variável exógena $x, z$ é o número da última defasagem da variável $x$ e $b$ é o instante a partir do qual o impacto de $x$ em $y$ passa a ser diferente de zero;

$\Phi(L)=1-\phi_{1} L-\phi_{2} L^{2} \ldots-\phi_{v} L^{v}$ é o polinômio relacionado ao componente autorregressivo do ruído $\varepsilon_{t}$;

$\Theta(L)=1-\theta_{1} L-\theta_{2} L^{2} \ldots-\theta_{w} L^{w}$ é o polinômio relacionado ao componente média móvel do ruído;

$\frac{\Gamma_{x}(L)}{\Omega(L)}=$ função de transferência de impulso da variável $x$ para a variável $y_{i}$ 


$$
\frac{\Phi(L)}{\Theta(L)}=\text { filtro } \operatorname{ARMA}(v, w) \text { que explica a propagação dos choques no }
$$

modelo. Essa propagação ao longo do tempo é interpretada como o componente de inércia da inflação em um dado segmento de $\operatorname{preços}^{13}$; e

$\varepsilon_{i, t}$ é um ruído branco.

A estabilidade do modelo requer que todas as raízes características dos polinômios $\Omega(L), \Phi(L)$ e $\Theta(L)$ estejam fora do círculo unitário.

A metodologia permite que cada variável explicativa tenha um polinômio $\Omega(L)$ associado diferente. No entanto, como não foram observadas diferenças significativas nesses polinômios (quando estimados isoladamente) e o ajuste dos modelos não foi comprometido, admitiu-se que estes são iguais para cada variável explicativa. As vantagens dessa estratégia são: a simplicidade na estimação e o aumento do grau de liberdade dos modelos ${ }^{14}$. Dessa forma, nos modelos estimados, o que distingue as funções de resposta a impulso são os polinômios situados no numerador.

O cálculo do impacto da variável de entrada $x$ na inflação de um determinado segmento foi executado utilizando a função de transferência de impulso. Como os valores das variáveis de entrada são conhecidos para o período em análise, foram utilizados os modelos estimados para obter um cálculo da contribuição de cada variável para a inflação por segmento.

A metodologia de identificação e verificação dos modelos de função de transferência, tal como apresentada por Box e Jenkins (1976) e Enders (2003) é feita através da análise da função de correlação cruzada entre as variáveis, o que permite a discriminação dos parâmetros que devem ser incluídos no modelo. Ou seja, é possível identificar quais dos parâmetros $\omega_{j}, \varphi_{h p, l}, \varphi_{\text {cambio,h }}, \varphi_{c o m m, s}$, $\varphi_{\text {inf } e, f}$ são significativos e, portanto, evitar a perda desnecessária de graus de liberdade. Para identificação do filtro ARMA utiliza-se a metodologia Box-Jenkins

(13) No modelo, a inércia total depende também do polinômio $\Omega(L)$. Por essa razão, mesmo que $n t$ seja ruído branco, existirá inércia por conta dos termos autorregressivos de $y$. A inexistência de inércia exige que $n t$ seja ruído branco e que $y$ não dependa de seus valores passados.

(14) Como a ordem $k$ dos denominadores individuais, determinados no processo de identificação, foi parecida, o modelo completo exigiria a estimação de uma grande quantidade de parâmetros. Se um dado modelo, por exemplo, tiver ordem $k$ igual a 4 em todas as funções de transferência seria necessário estimar 16 parâmetros apenas para os denominadores. Considerando a perda de observações por conta das defasagens, tal estimação reduziria drasticamente o grau de liberdade. Como os modelos estimados proporcionaram um bom ajuste aos dados e o objetivo é explicar a variação dos preços através das variáveis de entrada, a estimação conjunta de um único denominador parece ser adequada. 
padrão. A estimação pode ser feita por mínimos quadrados ou por máxima verossimilhança, quando forem incluídos termos de média móvel ${ }^{15}$.

A variável expectativa de inflação foi testada em todos os modelos, com dados de julho de 2001 a dezembro de 2009. A variável foi excluída das equações em que não foi significativa e os modelos foram estimados novamente para o período a partir de agosto de 1999. Como em Schwartzman (2006), testou-se a inclusão de dummies para a instabilidade política no segundo semestre de $2002^{16}$. No entanto, estas não foram significativas (ou contribuíram pouco para o ajuste do modelo) e foram excluídas dos modelos. A disponibilidade das séries utilizadas e as defasagens dos modelos inviabilizaram a inclusão da dummy testada no estudo de Minella et al. (2002), que menciona problemas de safras e choques de preços administrados no início de 2000.

Em alguns modelos foi incluída uma dummy para mudança de intercepto ou inclinação em janeiro de 2006. A justificativa foi a dificuldade de branqueamento do resíduo (ou identificação do termo $n_{t}$ ) em alguns modelos. Nestes casos, combinou-se a abordagem de função de transferência com a de análise de intervenção (Box; Jenkins, 1976). O critério para utilização dessa estratégia foi a realização do teste de Chow e a verificação de significância do parâmetro relacionado à dummy.

\subsection{Resultados das estimações}

Os determinantes macroeconômicos do IPCA por segmentos são apresentados a seguir. O Quadro 1 e a Tabela 5 mostram, respectivamente, os rótulos das variáveis utilizadas e os resultados dos testes de raiz unitária. As séries habitação monitorados e comunicação monitorados não foram dessazonalizadas, pois, ao serem retirados os efeitos sazonais, as séries apresentaram evidências de integração. Assim, optou-se por utilizá-las com a sazonalidade e identificar os componentes sazonais no filtro para os resíduos. O teste de raiz unitária utilizado foi o Augmented Dickey-Fuller (ADF) padrão.

(15) Foram utilizados os softwares EViews 6.0 e WinRATS 6.0 para identificar e estimar os modelos.

(16) Nos modelos com expectativa não foi possível efetuar o teste por conta da disponibilidade de dados. 

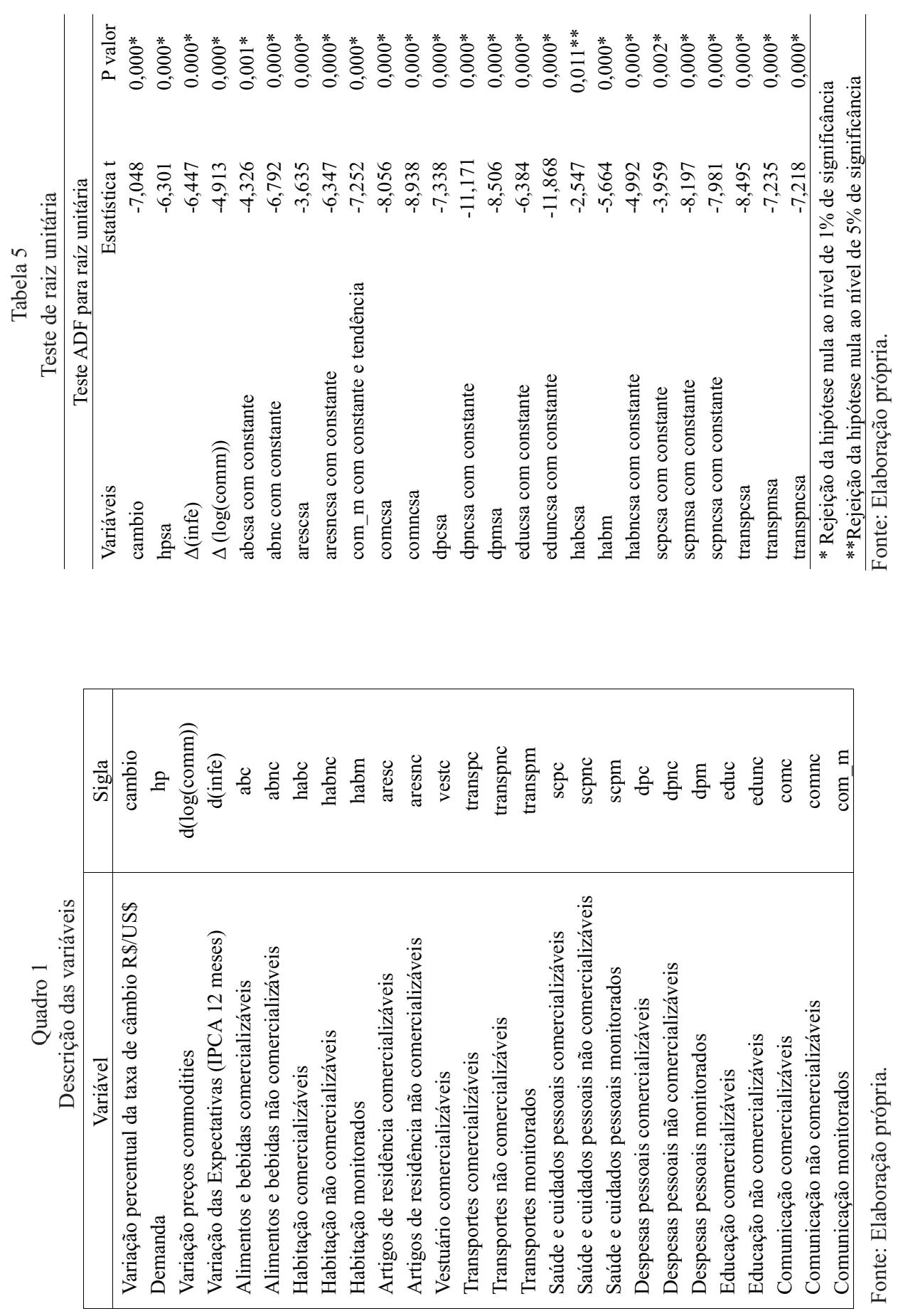
Pelos resultados do teste Ljung-Box para os resíduos e para o quadrado dos resíduos (Tabela 6), nota-se que não há evidência de autocorrelação e de heteroscedasticidade condicional nos modelos apresentados. A Tabela 7 mostra os coeficientes dos modelos estimados, com o nível de significância identificado por asteriscos. Os segmentos que tiveram mudança significativa no intercepto foram os preços monitorados dos grupos habitação e saúde e cuidados pessoais. No caso dos preços monitorados do grupo comunicação, ocorreu uma mudança na função de transferência resultante da redução do coeficiente de um dos termos autorregressivos. Os resultados apresentam uma evidência de que a dinâmica dos preços monitorados sofreu alteração entre 2005 e 2006. Essa mudança foi caracterizada pela redução do componente estrutural e, no caso do grupo comunicação, uma redução da magnitude das funções de transferência de impulso. É possível que tais alterações estejam relacionadas com as mudanças implementadas nos contratos de preços monitorados entre 2005 e 2006.

No caso dos segmentos despesas pessoais comercializáveis, habitação/ monitorados, saúde e cuidados pessoais/monitorados, transportes comercializáveis e transporte/monitorados, verificou-se a presença de heteroscedasticidade condicional, identificada pelo teste Ljung-Box para o quadrado dos resíduos e pelo teste Auto-Regressive Conditional Heteroscedastic (ARCH). Nestes casos, foram incluídos filtros ARCH e Generalized Autoregressive Conditional Heteroskedasticity (GARCH) nos modelos de modo a eliminar a autocorrelação do quadrado dos resíduos. Adicionalmente, incluiu-se uma dummy para mudança no nível da variância a partir de 2006 para os preços monitorados dos grupos habitação, saúde e cuidados pessoais e transportes. Os resultados mostram que, no caso dos preços monitorados dos grupos habitação e transportes, houve uma significativa redução da volatilidade da inflação depois de 2006. No segmento serviços pessoais monitorados ocorreu um pequeno aumento.

A partir das funções de resposta a impulso e dos valores observados das variáveis explicativas nos anos de 2005 a 2009, foram calculadas as contribuições de cada variável macroeconômica para a inflação dos segmentos ano a ano, exibidas na Tabela 8. Tais cálculos não foram aplicados para anos anteriores devido à disponibilidade de dados para as séries utilizadas nas estimações e por conta da elevada ordem das defasagens estabelecidas no processo de identificação para alguns modelos. A Tabela 8 está dividida em dois blocos. No primeiro, são apresentadas as contribuições de cada determinante para as inflações dos segmentos. No segundo, o valor estimado total da inflação de cada segmento nos anos considerados - obtido pela soma das contribuições dos determinantes - e a variação não explicada, que é o erro obtido subtraindo o valor estimado total da inflação efetivamente observada para o segmento. 


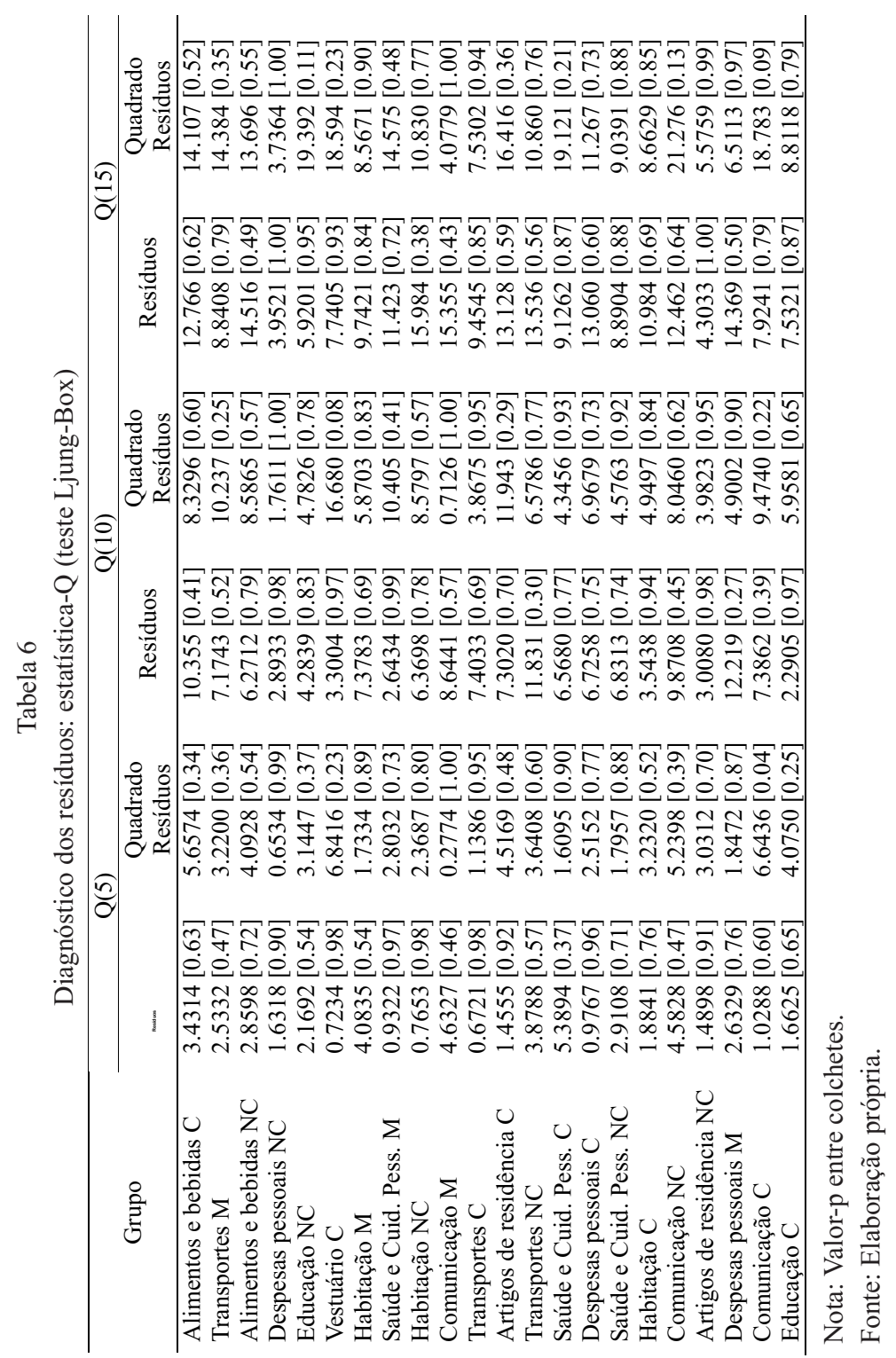




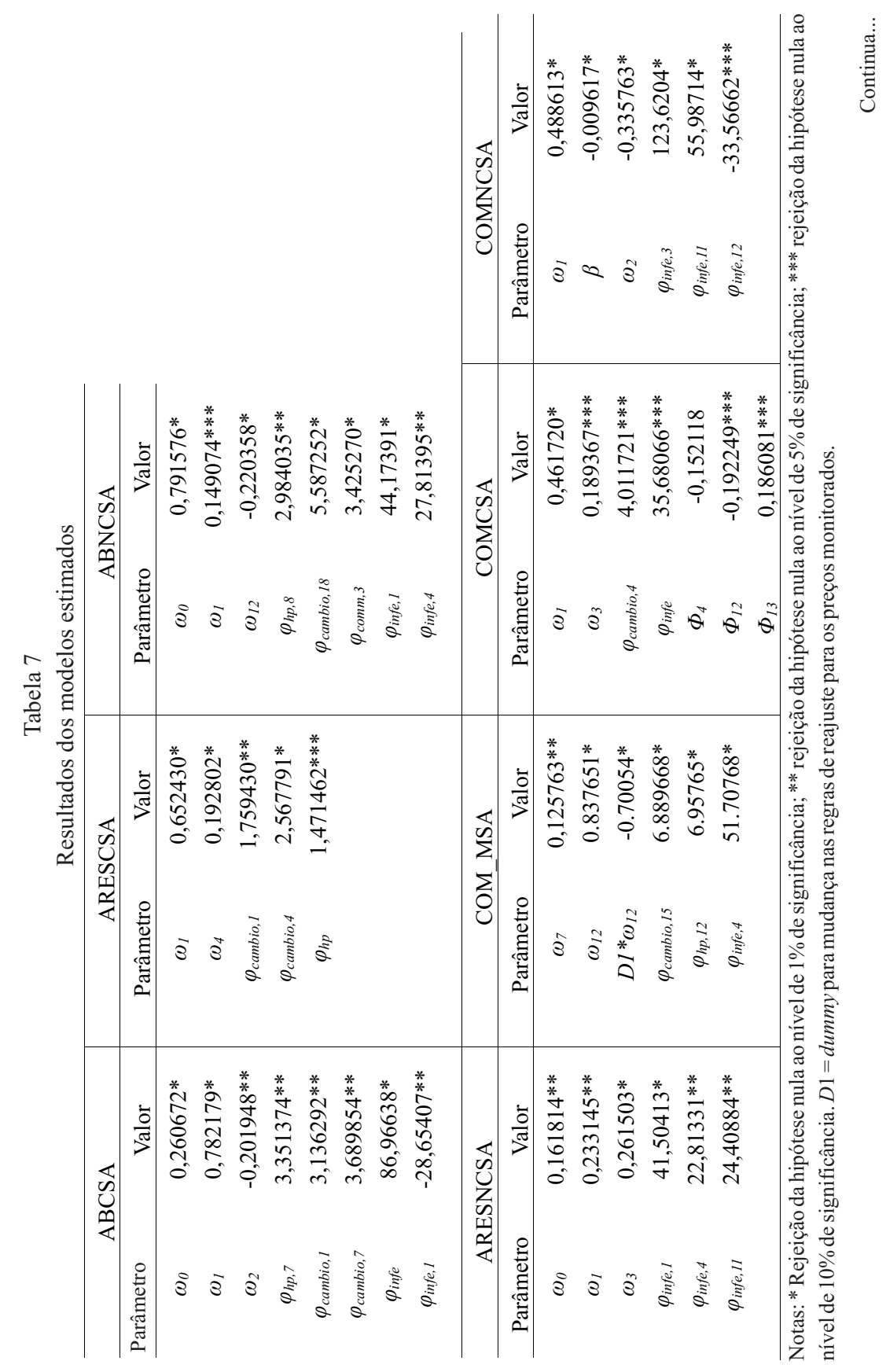




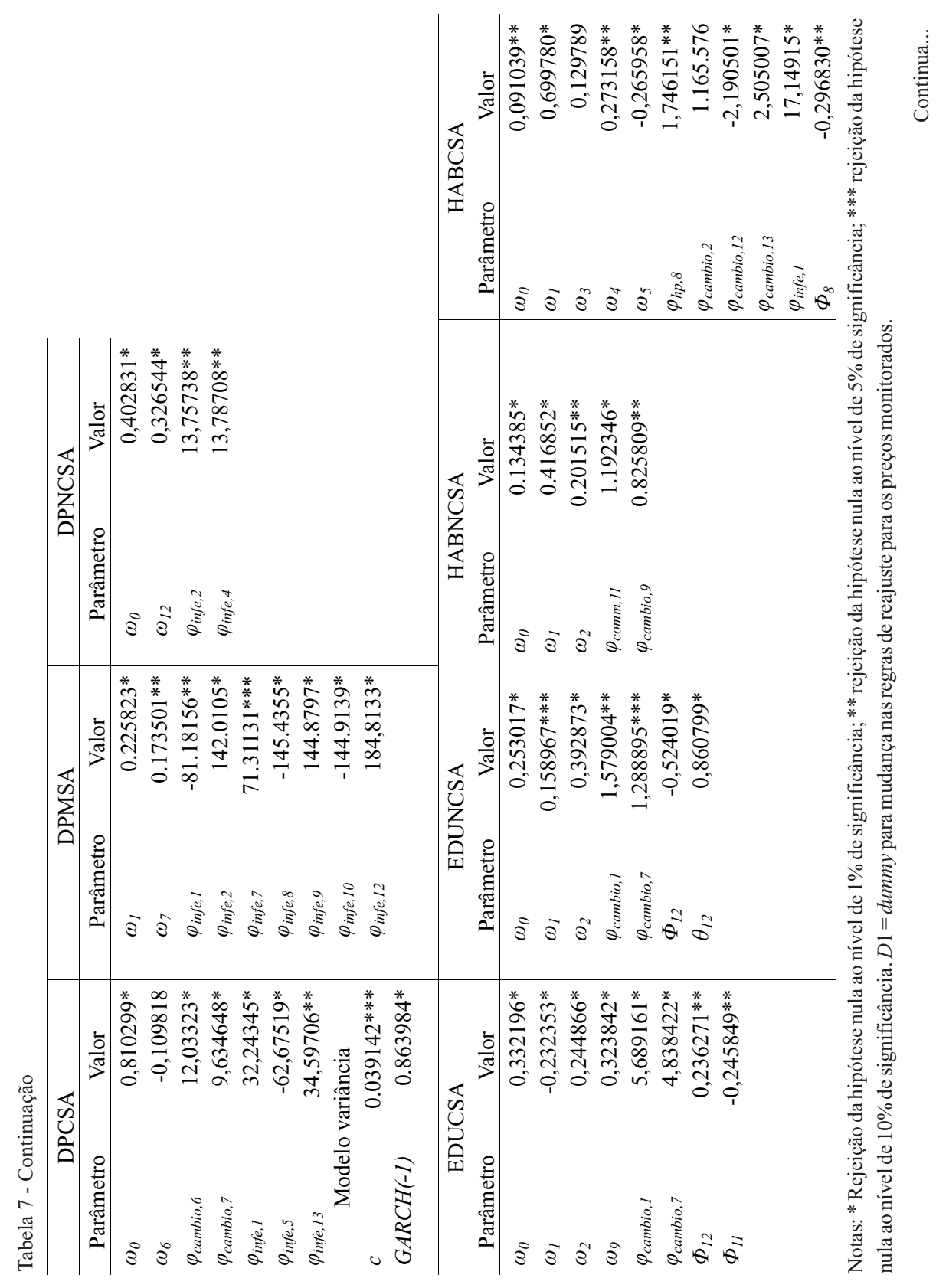




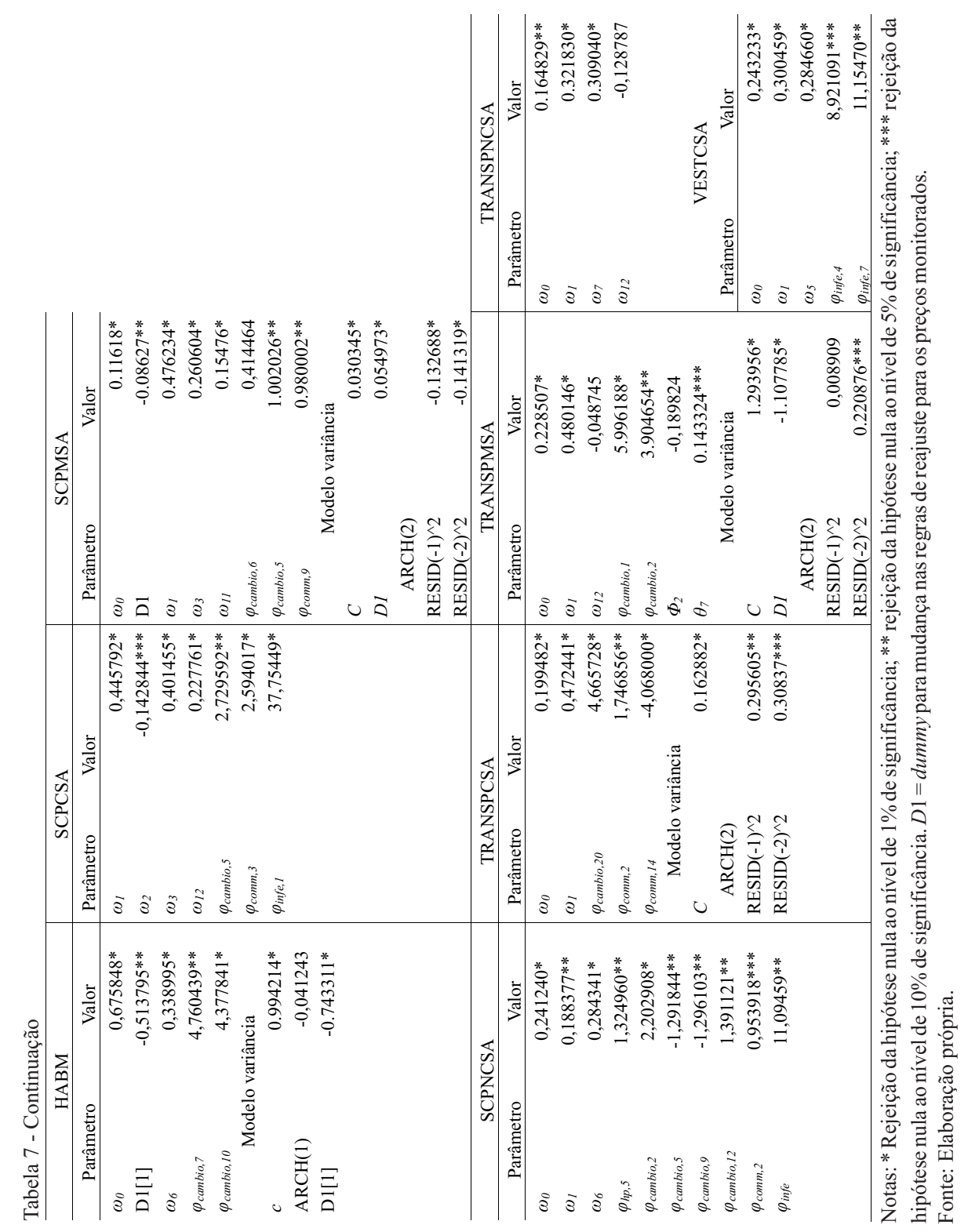




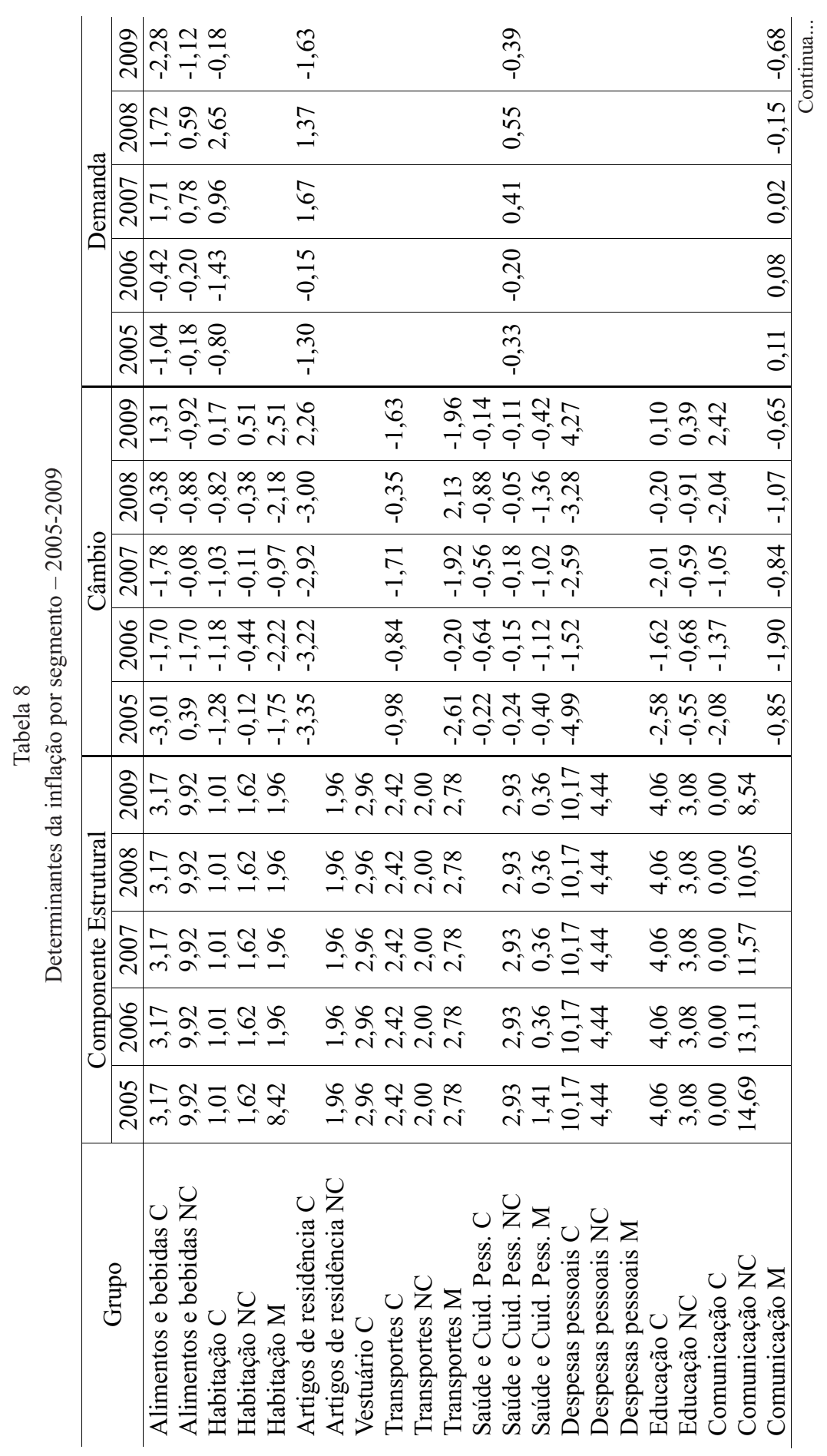




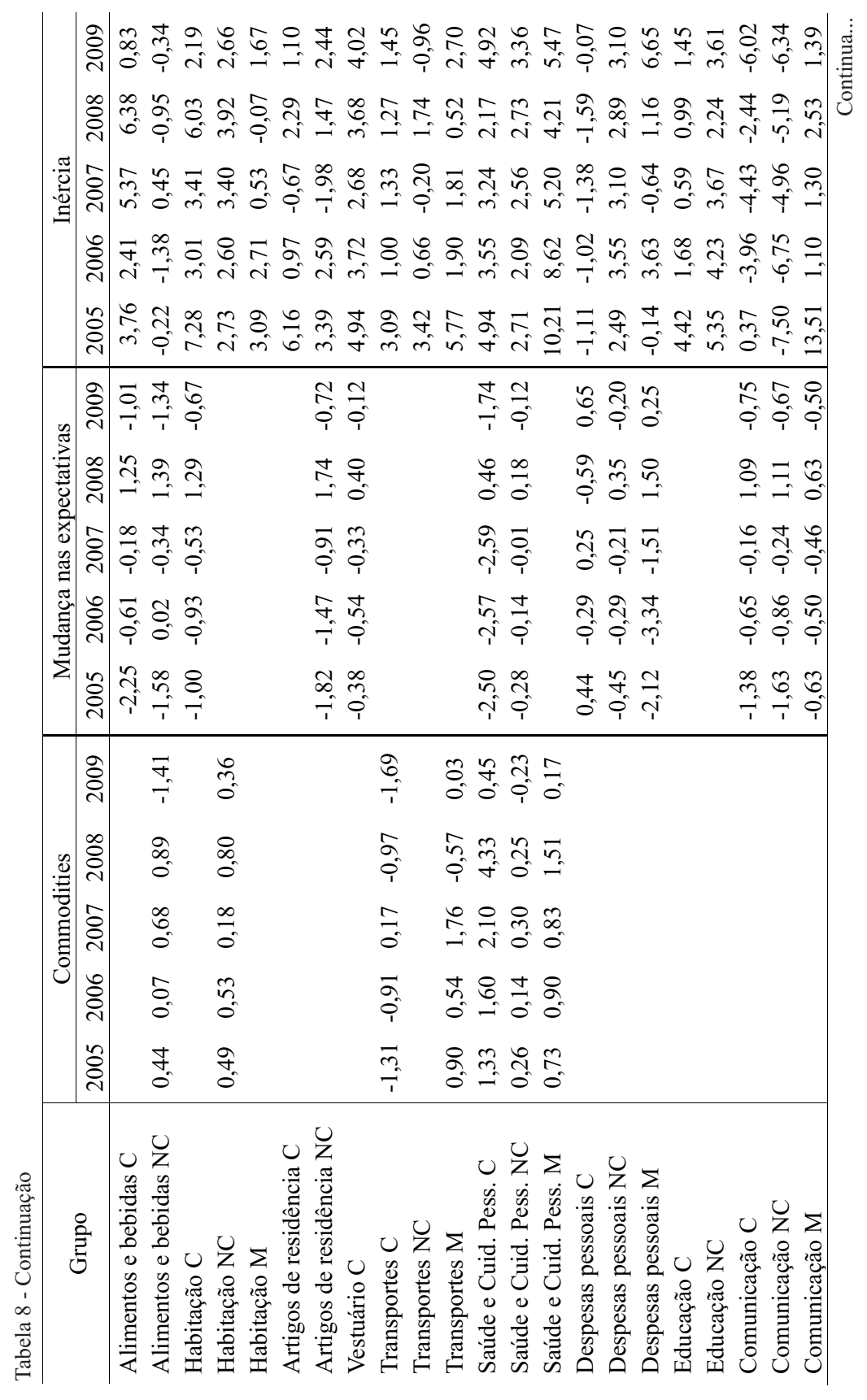




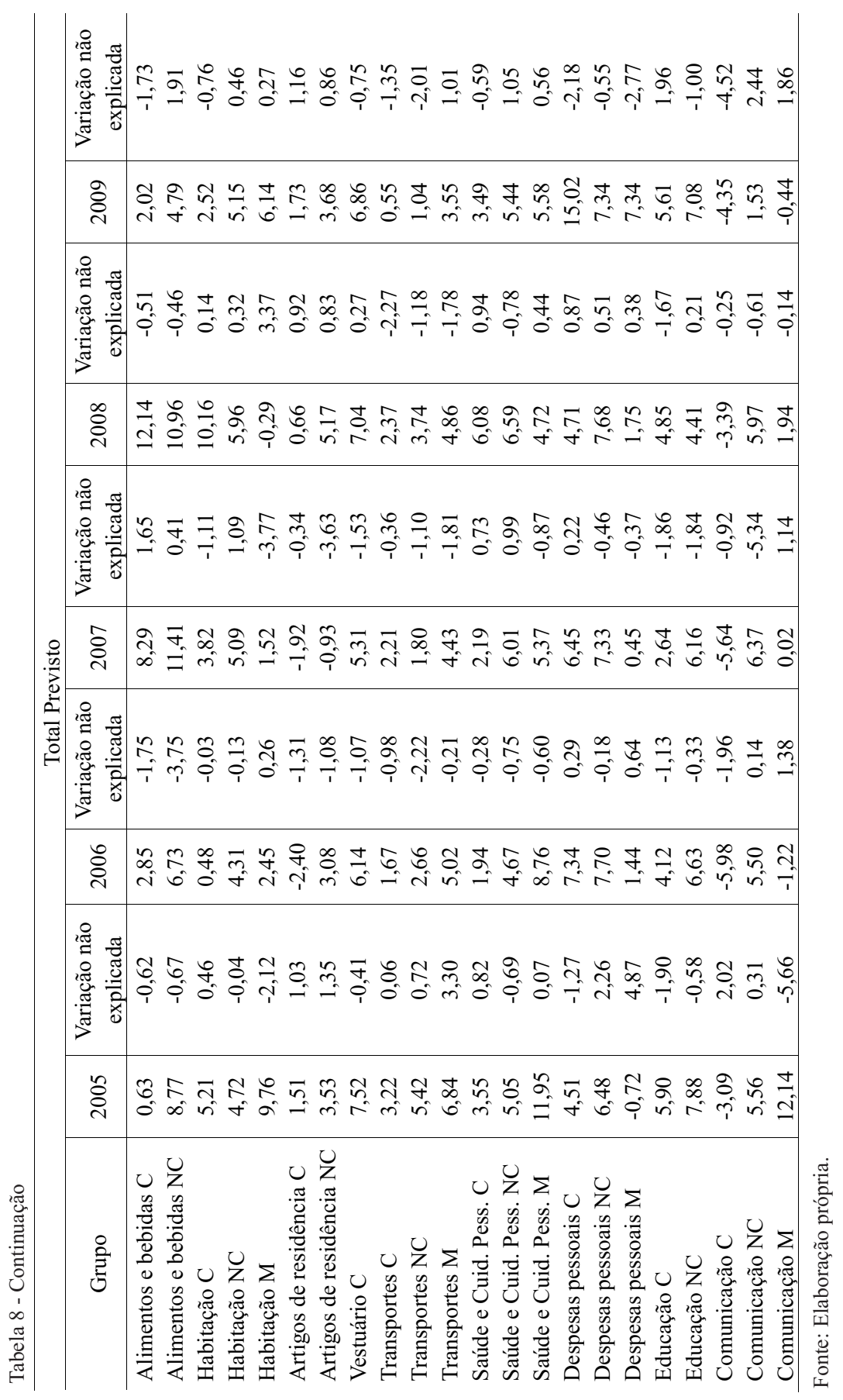


Dos segmentos destacados durante a análise da decomposição, nota-se que apresentam comportamentos diferentes. $\mathrm{Na}$ inflação do segmento transportes monitorados, chama atenção a diminuição da inércia inflacionária comparando 2005 com os anos posteriores. Isso está relacionado à quebra estrutural da variância, que por sua vez pode ser consequência da política de variação da tributação sobre a gasolina e óleo diesel justamente para atenuar a volatilidade. A inflação do segmento apresenta um componente estrutural de 2,78\%, bastante afetada pelo câmbio e pela inércia - mesmo após 2005 - e pelos preços de commodities em menor medida.

As novas regras de precificação do setor de energia elétrica implicaram transformações na dinâmica inflacionária do segmento habitação monitorados. Houve uma redução intensa do componente estrutural, que de 8,42\% até 2005 foi para $1,96 \%$ desde 2006 , e a quebra da variância refletiu-se em inércia menor após 2005. Ademais, o câmbio mostrou-se como o principal determinante macroeconômico da inflação do segmento.

No segmento comunicações monitorados, as regras de reajuste tarifário dos novos contratos de telefonia fixa estabelecidos em 2006 diminuíram os coeficientes da função de impulso resposta, o que causou a contração da inércia inflacionária: de 13,51\% em 2005, passou a 1,1\% em 2006, 1,3\% em 2007 e 2,53\% em 2009. Ainda assim, a inércia continua sendo o principal determinante da inflação no segmento, que também sofreu influência do câmbio, das expectativas inflacionárias e da demanda.

A inflação de alimentos e bebidas não comercializáveis é marcada por um elevado componente estrutural, de 9,92\%, que explica por que em quase todos os anos da década foi um dos segmentos que mais pressionaram o IPCA para cima. Todas as outras covariáveis consideradas afetaram a inflação do segmento, mas em magnitude muito menor em comparação com o componente estrutural.

Do segmento alimentos e bebidas comercializáveis, viu-se que seu comportamento é instável: em alguns anos é o que mais pressiona a inflação para cima, em outros é o que mais pressiona para baixo. A explicação desse fenômeno fica clara na Tabela 5, onde se vê que a inflação do segmento é afetada de maneira significativa por diversos determinantes. A inércia é o que mais se destaca, inclusive por sua volatilidade - era 3,76\% em 2005, vai a 2,41\% em 2006, 5,37\% em 2007, 6,38\% em 2008 e chega a 0,83\% em 2009. Mas outros determinantes têm grande importância: o componente estrutural de 3,17\%, o câmbio, a demanda e as expectativas inflacionárias.

Já a inflação de despesas pessoais não comercializáveis é determinada fundamentalmente pelo componente estrutural, de 4,44\%, e pela inércia, que oscilou entre $2,5 \%$ e $3,5 \%$. As expectativas inflacionárias também afetam o 
segmento, mas em magnitude muito menor. É provável que a inflação elevada desse segmento esteja relacionada à política de aumentos reais do salário mínimo, já que sua dinâmica segue o subitem empregado doméstico.

Por fim, quanto ao segundo bloco da tabela, nota-se que a variação não explicada pelo modelo é grande para vários segmentos. Isso, em grande parte, decorre da abordagem utilizada de testar os mesmos determinantes para todos os segmentos. Fatores diversos que afetem especificamente a inflação de cada segmento não foram considerados, o que exigiria estudos específicos por setor. Ainda assim, embora as variações não explicadas sejam consideráveis ano a ano, elas tendem a se anular para o período todo, o que preserva a relevância dos resultados do modelo para tendências de longo prazo.

\section{Considerações finais}

A decomposição do IPCA mostra que há diferenças substanciais no comportamento de diferentes agrupamentos de preços e que, portanto, estudos desagregados têm muito a acrescentar para o debate sobre políticas de combate à inflação. Em particular, constatou-se que uma parcela limitada dos bens respondeu sistematicamente por boa parte da pressão inflacionária acima da meta. De 2000 a 2005, destacaram-se os preços monitorados dos grupos: transportes, habitação e comunicação. De 2006 a 2009, esse papel coube aos segmentos alimentos e bebidas não comercializáveis e despesas pessoais não comercializáveis, enquanto os alimentos e bebidas comercializáveis pressionaram para cima ou para baixo da meta conforme o ano.

As estimativas de determinantes da inflação por modelos de função de transferência revelaram que as mudanças de comportamento nos preços monitorados podem ser atribuídas a quebras estruturais ocorridas entre os anos 2005 e 2006. Tudo indica que tais quebras são frutos de políticas governamentais adotadas explicitamente para diminuir a inflação estruturalmente elevada nesses segmentos, como revisões em regras de reajuste nas tarifas de energia elétrica e telefonia fixa, além de tributação variável para diminuir a volatilidade da gasolina.

O êxito na manutenção de uma inflação baixa durante a última década é geralmente creditado unicamente ao regime de metas. Contudo, o aparente sucesso dessas políticas alternativas de combate à inflação questiona tal diagnóstico. Certamente a política monetária foi crucial, pois nota-se o impacto negativo de determinantes associados à taxa de juros - câmbio, expectativas inflacionárias e demanda - sobre a inflação de vários dos segmentos. Em especial, o segmento alimentos e bebidas comercializáveis, cujo peso no IPCA é elevado, é bastante sensível a esses três determinantes. 
Ainda assim, os resultados do artigo oferecem evidências a favor do uso de outras políticas para combater a inflação quando há grupos de bens com inflação sistematicamente acima da meta. $\mathrm{O}$ regime de metas de inflação pressupõe que a política monetária é eficaz em segurar o aumento dos preços via contenção da demanda agregada. Porém, se o seu efeito é limitado sobre alguns grupos de bens com muita influência sobre o índice geral, ela deve exercer um impacto sobre os outros preços suficientemente grande para que isso se reflita no IPCA. Além de provocar distorções no sistema de preços relativos desfavoráveis aos preços mais sensíveis à política monetária, isso resulta em taxas de juros sistematicamente elevadas e com pouca margem para redução. Enquanto houver grupos de preços influentes com inflação estruturalmente acima da meta, será pequeno o espaço para reduções substanciais da taxa de juros, ainda mais em uma economia crescendo a taxas elevadas como se espera para os próximos anos. Esse é o caso dos alimentos e bebidas não comercializáveis, cujo componente estrutural da inflação é de quase $10 \%$, e de despesas pessoais não comercializáveis, que tem um componente estrutural de $4,44 \%$ e apresenta inércia ao redor de $3 \%$ ao ano.

\section{Referências bibliográficas}

BCB - BANCO CENTRAL DO BRASIL. Sistema de séries temporais. Disponível em: $<$ http://www4.bcb.gov.br/?SERIESTEMP>. Acesso em: jun. 2010.

BARBOSA, N.; PEREIRA DE SOUZA, J. A. A inflexão do governo Lula: política econômica, crescimento e distribuição de renda. In: SADER, E.; GARCIA, M. A. (Org.). Brasil: entre o passado e o futuro. São Paulo: Boitempo, 2010.

BOX, G. E. P.; JENKINS, G. M. Time series analysis: forecasting and control. Revised ed. Holden-Day, 1976.

CARNEIRO, D. D. et al. Mecanismos não-lineares de repasse cambial para o IPCA. Revista de Economia e Administração, v. 3, n. 1, jan./mar. 2002.

ENDERS, W. Applied econometric time series. 2nd ed. Wiley, 2003.

FERNANDEZ SILVA, E. Reajuste e revisão de preços administrados em transporte: regras e realidade. In: MATTOS, C. et al. (Org.). Política de preços públicos no Brasil. 2. ed. Brasília: Câmara dos Deputados, Coordenação de Publicações, 2007. p. 157-202.

INSTITUTO BRASILEIRO DE GEOGRAFIA E ESTATÍSTICA (IBGE). Sistema nacional de indices de preços ao consumidor: cálculo dos itens sazonais alimentícios. Série Relatórios Metodológicos, v. 32, 62p. Rio de Janeiro: IBGE, 2005.

. Sistema nacional de índices de preços ao consumidor: métodos de cálculos. Série Relatórios Metodológicos, v. 14. Rio de Janeiro: IBGE, 2007.

IPEADATA. Ipeadata macroeconômico. Disponível em: <http://ipeadata.ipea.gov.br/>. Acesso em: jun. 2010. 
MATTOS, C. Um panorama das tarifas de telecomunicações no Brasil pós-privatização. In: MATtOS, C. et al. (Org.). Política de preços públicos no Brasil. 2. ed. Brasília: Câmara dos Deputados, Coordenação de Publicações, 2007. p. 39-48.

MINELLA, A. et al. Inflation targeting in Brazil: lessons and challenges. Banco Central do Brasil, 2002. p. 1-47. (Working Paper Series, n. 53).

MUINHOS, M. K.; ALVES, S. A. L. Medium-size macroeconomic model for the Brazilian economy. Brasília: Banco Central do Brasil, 2003. (Working Paper Series, n. 64).

NONNENBERG, M. J. B.; LAMEIRAS, M. A. P. Preços das commodities e o IPA. Boletim de Conjuntura, IPEA, n. 69, jun. 2005 (Nota Técnica).

ROCHA DE SOUSA, F. J. Regras de preço no setor de energia. In: MATTOS, C. et al. (Org.). Política de preços públicos no Brasil. 2. ed. Brasília: Câmara dos Deputados, Coordenação de Publicações, 2007. p. 81-107.

SACHSIDA, A.; MENDONÇA. M. J. Reexaminando a curva de Phillips brasileira com dados de seis regiões metropolitanas. Ipea, 2009. (Texto para Discussão, n. 1.430).

; RIBEIRO, M.; DOS SANTOS, C. H. A curva de Phillips e a experiência brasileira. Ipea, 2009. (Texto para Discussão, n. 1.429).

SCHWARTZMAN, F. F. Estimativa de curva de Phillips para o Brasil com preços desagregados. Economia Aplicada, v. 10, n. 1, p. 137-155, jan./mar. 2006.

TOMBINI, A. S.; ALVES, S. A. L. The recent Brazilian disinflation process and costs. Central Bank of Brasil, Jun. 2006. (Working Paper Series, n. 109). 
Thiago Sevilhano Martinez / Vinícius dos Santos Cerqueira

\section{Apêndice A}

Quadro 1A

Classificação dos subitens do IPCA por tipo de precificação

\begin{tabular}{|c|c|}
\hline \multicolumn{2}{|c|}{ Comercializáveis } \\
\hline \multicolumn{2}{|l|}{ 1.Alimentação e bebidas } \\
\hline 11.Alimentação no domicílio & 42.Calçados e acessórios \\
\hline 1101.Cereais, leguminosas e oleaginosas & 4201.Calçados e acessórios \\
\hline 1101002.Arroz & 43.Joias e bijuterias \\
\hline 1102.Farinhas, féculas e massas & 4301.Joias e bijuterias \\
\hline 1102001.Farinha de arroz & 44. Tecidos e armarinho \\
\hline 1102006.Macarrão & 4401. Tecidos e armarinho \\
\hline \multicolumn{2}{|l|}{ 1102008.Fubá de milho } \\
\hline 1102012.Farinha de trigo & 5.Transportes \\
\hline 1102013.Farinha vitaminada & 51.Transportes \\
\hline apenas em 2006-2009 & 5102. Veículo próprio \\
\hline 1102029.Massa semipreparada & 5102001.Automóvel novo \\
\hline apenas em 1999-2006 & 5102009.Acessórios e peças \\
\hline 1102002.Aveia em flocos & 5102010.Pneu e câmara-de-ar \\
\hline 1102009.Amido de milho & 5102053.Motocicleta \\
\hline 1102010.Flocos de milho & apenas em 1999-2006 \\
\hline 1102016.Flocos de cereais & 5102054.Camioneta \\
\hline 1102028.Cremogema & 5104.Combustíveis (veículos) \\
\hline 1102038.Massa para pizza & apenas em 2006-2009 \\
\hline 1102040.Massa para pastel & 5104002.Álcool* \\
\hline \multicolumn{2}{|l|}{ 1102043.Massa para lasanha } \\
\hline 1104.Açúcares e derivados & 6.Saúde e cuidados pessoais \\
\hline 1107.Carnes & 61.Produtos farmacêuticos e óticos \\
\hline 1109. Carnes e peixes industrializados & apenas em 1999-2006 \\
\hline 1110.Aves e ovos & 6101.Produtos farmacêuticos* \\
\hline 1110009.Frango / Frango inteiro & 6102.Produtos óticos / Óculos e lentes \\
\hline apenas em 2006-2009 & 63.Cuidados pessoais \\
\hline 1110010.Frango em pedaços* & 6301.Higiene pessoal \\
\hline \multicolumn{2}{|l|}{ 1111.Leites e derivados } \\
\hline 1112.Panificados & 7.Despesas pessoais \\
\hline 1113.Óleos e gorduras & 72.Recreação, fumo e filmes \\
\hline 1114.Bebidas e infusões & 7201.Recreação \\
\hline 1115.Enlatados e conservas & 7201008.Disco laser / Disco \\
\hline 1116.Sal e condimentos & $\begin{array}{l}\text { 7201010.Instrumento musical } \\
\text { 7201019.Bicicleta }\end{array}$ \\
\hline 2.Habitação & 7201020.Alimento para animais / para cães \\
\hline 21.Encargos e manutenção & 7201023.Brinquedos \\
\hline 2103.Reparos & 7201083.Material esportivo \\
\hline 2103005.Ferragens & apenas em 1999-2006 \\
\hline 2103008.Material de eletricidade & 7201069.Bicicleta ergométrica \\
\hline 2103009.Material de pintura & 7201085.Fita de vídeo gravada \\
\hline $\begin{array}{l}\text { 2103014. Tinta } \\
2103031 \text { Ferramentas }\end{array}$ & 7201091.Arma de fogo \\
\hline \multirow{2}{*}{$\begin{array}{l}\text { 2103031.Ferramentas } \\
\text { apenas em 2006-2009 }\end{array}$} & 7201097.Alimento para animais (exceto cães) \\
\hline & 7202.Fumo \\
\hline 2103041.Material hidráulico & 7202041.Cigarro \\
\hline \multirow{2}{*}{$\begin{array}{r}\text { apenas em 1999-2006 } \\
2103012 \text { Material de vidro }\end{array}$} & 7203.Fotografia e filmagem \\
\hline & 7203001.Máquina fotográfica \\
\hline \multirow[t]{2}{*}{ 2104.Artigos de limpeza } & 7203002. Filme e flash descartável \\
\hline & apenas em 1999-2006 \\
\hline 3.Artigos de residência & 7203003.Revelação e cópia* \\
\hline 31.Móveis e utensílios & 7203004.Filmadora \\
\hline 3101.Mobiliário & 7203006. Fita de video virgem \\
\hline 3102.Utensílios e enfeites & \\
\hline 3103.Cama, mesa e banho & 8.Educação \\
\hline 32.Aparelhos eletroeletrônicos & 81.Cursos, leitura e papelaria \\
\hline 3201.Eletrodomésticos e equipamentos & 8103.Papelaria \\
\hline 3202.TV, som e informática & 8103001.Caderno \\
\hline & 8103014.Artigos de papelaria \\
\hline 4.Vestuário & \\
\hline 41.Roupas & 9.Comunicação \\
\hline 4101. Roupa masculina & 91.Comunicação \\
\hline 4102.Roupa feminina & 9101.Comunicação \\
\hline 4103.Roupa infantil & 9101019.Aparelho telefônico \\
\hline
\end{tabular}




\begin{tabular}{|c|c|}
\hline \multicolumn{2}{|c|}{ Não-Comercializáveis } \\
\hline \multicolumn{2}{|l|}{ 1.Alimentação e bebidas } \\
\hline \multicolumn{2}{|l|}{ 11.Alimentação no domicílio } \\
\hline 1101.Cereais, leguminosas e oleaginosas & apenas em 2006-2009 \\
\hline 1101051 a $1101073 . F e i j a ̃ o$ (vários tipos) & 5102033.Reboque \\
\hline apenas em 2006-2009 & 5102051.Aluguel de veículo \\
\hline 1101084.Fava & \\
\hline apenas em 1999-2006 & 6.Saúde e cuidados pessoais \\
\hline 1101079. Milho em grão & 62.Serviços de saúde \\
\hline 1101080. Milho em espiga & 6201.Serviços médicos e dentários \\
\hline 1102.Farinhas, féculas e massas & 6201002.Médico \\
\hline 1102023. Farinha de mandioca & 6201003.Dentista \\
\hline apenas em 1999-2006 & 6201005.Aparelho dentário \\
\hline 1102022.Fécula de mandioca & 6201006.Artigos ortopédicos \\
\hline 1103.Tubérculos, raízes e legumes & 6201008.Tratamento psicológico e fisioterápico \\
\hline 1105.Hortaliças e verduras & 6202. Serviços laboratoriais e hospitalares \\
\hline 1106.Frutas & 6202003.Exame de laboratório \\
\hline 1108.Pescados & 6202004. Hospitalização e cirurgia \\
\hline 1110.Aves e ovos & 6202006.Eletrodiagnóstico \\
\hline 1110044. Ovo de galinha & 6202013.Radiografia \\
\hline apenas em 1999-2006 & apenas em 2006-2009 \\
\hline 1110011.Peito de frango* & 6202008.Asilo \\
\hline 1110012.Coxa de frango* & \\
\hline 1110014.Asa de frango* & 7.Despesas pessoais \\
\hline item existente apenas em 1999-2006 & 71.Serviços pessoais \\
\hline 1117.Alimentos prontos & 7101.Serviços pessoais \\
\hline 12.Alimentação fora do domicílio & 7101001.Costureira \\
\hline 1201.Alimentação fora do domicílio & 7101005. Manicure e pedicure \\
\hline & 7101008.Barbeiro \\
\hline 2.Habitação & 7101009.Cabeleireiro \\
\hline 21.Encargos e manutenção & 7101010.Empregado doméstico \\
\hline 2101.Aluguel e taxas & 7101014.Depilação \\
\hline 2101001.Aluguel residencial & 7101036.Despachante \\
\hline 2101002.Condomínio & 7101076. Serviço bancário \\
\hline 2101012.Mudança & 7101090. Conselho de classe \\
\hline apenas em 1999-2006 & apenas em 1999-2006 \\
\hline 2101008.Compra de água & 7101004.Tinturaria e lavanderia \\
\hline 2103.Reparos & 7101018.Massagem e sauna \\
\hline apenas em 2006-2009 & 7101038.Serviço funerário \\
\hline 2103032.Azulejo e piso & 7101051.Alfaiate \\
\hline 2103039. Cimento & 72.Recreação, fumo e filmes \\
\hline 2103040.Tijolo & 7201.Recreação \\
\hline 2103042.Mão-de-obra & 7201001.Cinema \\
\hline 2103048.Areia & 7201003.Ingresso para jogo \\
\hline 2103049.Pedras & 7201006. Clube \\
\hline 22.Combustíveis e energia & 7201052.Aluguel de DVD e fita de videocassete \\
\hline 2201.Combustíveis (domésticos) & 7201054.Boite, danceteria e discoteca \\
\hline 2201003.Carvão vegetal & 7201068.Motel \\
\hline & 7201090.Hotel \\
\hline 3.Artigos de residência & apenas em 2006-2009 \\
\hline 33. Consertos e manutenção & 7201018. Compra e tratamento de animais \\
\hline 3301.Consertos e manutenção & apenas em 1999-2006 \\
\hline 3301002. Conserto de refrigerador e freezer & 7201051.Teatro \\
\hline 3301009. Conserto de aparelho de som & 7201066.Aluguel de fita de vídeo-game \\
\hline 3301015. Conserto de máquina de lavar/secar roupa & 7201084.Telesena \\
\hline 3301022. Reforma de estofado & 7201088. Bingo \\
\hline 3301023. Conserto de bomba d'água & 7201095.Excursão \\
\hline apenas em 2006-2009 & 7203.Fotografia e filmagem \\
\hline 3301006. Conserto de televisor & apenas em 2006-2009 \\
\hline apenas em 1999-2006 & 7203003.Revelação e cópia* \\
\hline 3301012. Conserto de vídeo-cassete & \\
\hline 3301021. Conserto de condicionador de ar & 8.Educação \\
\hline 3301024. Manutenção de caixa d'água, fossa, etc. & 81.Cursos, leitura e papelaria \\
\hline & 8101.Cursos \\
\hline 5.Transportes & 8102.Leitura \\
\hline 51.Transportes & 8103.Papelaria \\
\hline 5101.Transporte público & 8103002.Fotocópia \\
\hline 5101026.Transporte escolar & torna-se item apenas em 2006-2009 \\
\hline 5102. Veículo próprio & 8104.Cursos diversos \\
\hline 5102005. Seguro voluntário de veículo & 9.Comunicação \\
\hline 5102011. Conserto de automóvel & 91.Comunicação \\
\hline 5102013.Estacionamento & 9101.Comunicação \\
\hline 5102019.Lubrificação e lavagem & 9101010.TV a cabo \\
\hline 5102020.Automóvel usado & apenas em 2006-2009 \\
\hline 5102037.Pintura de veículo & 9101018.Acesso à internet \\
\hline
\end{tabular}




\begin{tabular}{|c|c|}
\hline \multicolumn{2}{|c|}{ Monitorados } \\
\hline 2.Habitação & \\
\hline \multicolumn{2}{|l|}{ 21.Encargos e manutenção } \\
\hline 2101.Aluguel e taxas & 5104.Combustíveis (veículos) \\
\hline 2101004.Taxa de água e esgoto & 5104001.Gasolina \\
\hline apenas em 1999-2006 & 5104003.Óleo diesel \\
\hline 2101003.Imposto predial & apenas em 2006-2009 \\
\hline 22.Combustíveis e energia & 5104005.Gás veicular \\
\hline 2201.Combustíveis (domésticos) & apenas em 1999-2006 \\
\hline 2201004.Gás de botijão & 5104002.Álcool* \\
\hline \multicolumn{2}{|l|}{ 2201005.Gás encanado } \\
\hline 2202.Energia elétrica residencial & 6.Saúde e cuidados pessoais \\
\hline \multirow[t]{2}{*}{ 2202003.Energia elétrica residencial } & 61.Produtos farmacêuticos e óticos \\
\hline & apenas em 2006-2009 \\
\hline 5.Transportes & 6101.Produtos farmacêuticos* \\
\hline 51.Transportes & 62.Serviços de saúde \\
\hline 5101.Transporte público & 6203.Plano de saúde \\
\hline 5101001.Onibus urbano & 6203001.Plano de saúde \\
\hline \multicolumn{2}{|l|}{ 5101002.Táxi } \\
\hline 5101004.Trem & 7.Despesas pessoais \\
\hline 5101006.Ônibus intermunicipal & 71.Serviços pessoais \\
\hline 5101007.Ônibus interestadual & 7101.Serviços pessoais \\
\hline 5101009.Ferry-boat & 7101034.Cartório \\
\hline 5101010.Avião & 72.Recreação, fumo e filmes \\
\hline 5101011.Metrô & 7201.Recreação \\
\hline 5101022.Barco & 7201063.Jogos de azar / lotéricos \\
\hline \multicolumn{2}{|l|}{ apenas em 1999-2006 } \\
\hline \multirow[t]{2}{*}{ 5101020.Navio } & 9.Comunicação \\
\hline & 91.Comunicação \\
\hline 5102.Veículo próprio & 9101.Comunicação \\
\hline 5102004.Emplacamento e licença & 9101001.Correio \\
\hline 5102007.Óleo & 9101002.Telefone fixo \\
\hline 5102015.Pedágio & 9101003.Telefone público \\
\hline apenas em 2006-2009 & 9101008.Telefone celular \\
\hline 5102006.Multa & \\
\hline
\end{tabular}

Fonte: IBGE e BCB. Elaboração própria.

Nota: * Itens e subitens que sofreram mudanças de classificação pelo Banco Central

“apenas em 1999-2006": itens e subitens excluídos do IPCA na revisão da cesta em 2006.

“apenas em 2006-2009”: itens e subitens incluídos no IPCA na revisão da cesta em 2006. 
Estrutura da inflação brasileira: determinantes e desagregação do IPCA

Apêndice B

Tabela 1B - Classificação do IPCA por Segmentos - Inflação (ago/99 - dez/04)

\begin{tabular}{|c|c|c|c|c|c|c|c|c|c|c|c|}
\hline \multicolumn{8}{|c|}{ Grupos do IPCA } & \multicolumn{4}{|c|}{ Tipo de precificação } \\
\hline \multicolumn{3}{|c|}{ 1.Alimentação e bebidas } & \multicolumn{3}{|c|}{ 4.Vestuário } & \multicolumn{2}{|c|}{ 7.Despesas pessoais } & \multicolumn{4}{|c|}{ c. Comercializáveis } \\
\hline \multicolumn{3}{|c|}{ 2.Habitação } & \multicolumn{3}{|c|}{ 5.Transportes } & 8.Educa & & nc. & Tão-comer & ializáveis & \\
\hline 3.Arti & de residên & & 6.Saúde & cuidados & essoais & 9.Comu & cação & $\mathrm{m}$. & Monitorad & & \\
\hline & $1 . \mathrm{c}$ & 1.nc & 2.c & 2.nc & $2 . \mathrm{m}$ & $3 . c$ & 3.nc & 4.c & $5 . \mathrm{c}$ & $5 . \mathrm{nc}$ & $5 . \mathrm{m}$ \\
\hline ago/99 & 0,35 & 0,32 & $-0,27$ & $-0,08$ & 2,08 & 0,06 & 0,27 & $-0,12$ & 0,10 & 1,05 & 2,09 \\
\hline set/99 & 0,41 & 0,33 & 0,99 & $-0,34$ & 0,65 & 0,15 & $-0,08$ & 0,35 & 0,10 & 0,91 & 0,58 \\
\hline out/99 & 2,91 & 0,25 & 0,85 & $-0,25$ & 0,16 & 0,52 & $-1,75$ & 1,04 & 9,72 & 1,34 & 1,49 \\
\hline nov/99 & 2,10 & 0,54 & 0,87 & $-0,05$ & 0,88 & 0,83 & 1,87 & 0,61 & 0,16 & 0,88 & 3,55 \\
\hline $\operatorname{dez} / 99$ & 1,76 & 1,26 & 0,31 & 0,01 & 0,85 & 0,65 & 0,27 & 0,69 & 0,11 & $-0,66$ & 0,83 \\
\hline $\mathrm{jan} / 00$ & 0,63 & 1,40 & 0,58 & 0,04 & 0,28 & 0,32 & 1,76 & 0,21 & 0,11 & 0,78 & 0,35 \\
\hline $\mathrm{fev} / 00$ & $-0,37$ & 0,27 & 0,80 & $-0,03$ & $-0,08$ & 0,65 & $-3,84$ & $-0,67$ & 1,10 & 1,46 & $-0,33$ \\
\hline $\mathrm{mar} / 00$ & $-0,92$ & 0,94 & 1,44 & $-0,16$ & 0,29 & 0,37 & $-0,76$ & $-1,44$ & 0,50 & 1,22 & 2,36 \\
\hline $\mathrm{abr} / 00$ & $-0,55$ & 0,31 & 1,02 & $-0,23$ & 0,07 & 0,20 & 0,10 & 0,72 & 0,85 & 1,20 & 0,08 \\
\hline $\mathrm{mai} / 00$ & $-0,56$ & 0,01 & 0,58 & $-0,07$ & 0,98 & 0,22 & 0,67 & 0,35 & 0,18 & 0,52 & $-0,05$ \\
\hline jun/00 & 0,81 & $-0,75$ & $-0,12$ & $-0,30$ & 0,27 & 0,34 & 1,39 & 0,92 & 0,03 & 0,94 & $-0,34$ \\
\hline $\mathrm{jul} / 00$ & 2,92 & $-0,02$ & 0,18 & $-0,34$ & 3,22 & 0,36 & $-0,13$ & 0,79 & 1,07 & 0,51 & 4,82 \\
\hline $\mathrm{ago} / 00$ & 2,41 & 1,93 & $-0,30$ & $-0,05$ & 1,04 & 0,85 & 0,33 & 0,42 & 0,60 & 0,89 & 4,26 \\
\hline set $/ 00$ & 0,40 & 1,01 & 0,31 & $-0,06$ & 0,31 & 0,62 & 0,56 & 0,57 & $-0,36$ & 1,06 & $-0,30$ \\
\hline out $/ 00$ & $-0,39$ & 1,25 & 0,10 & $-0,04$ & 0,11 & 0,38 & 0,50 & 0,63 & 0,11 & 0,87 & $-0,15$ \\
\hline nov $/ 00$ & $-0,35$ & 0,79 & 0,10 & 0,06 & 1,53 & 0,46 & 1,36 & 0,51 & $-0,20$ & 0,05 & 1,34 \\
\hline $\operatorname{dez} / 00$ & $-0,51$ & $-0,13$ & 0,07 & 0,02 & 2,04 & 0,59 & 0,07 & 1,07 & 0,18 & $-1,12$ & 3,70 \\
\hline $\mathrm{jan} / 01$ & 0,25 & 1,58 & 0,52 & 0,11 & 1,19 & 0,58 & 0,73 & $-0,05$ & 0,37 & 0,46 & 0,95 \\
\hline fev/01 & $-0,34$ & 0,90 & 0,62 & 0,08 & 0,61 & 0,16 & $-0,24$ & $-0,56$ & 0,52 & 0,88 & 0,81 \\
\hline $\mathrm{mar} / 01$ & 0,69 & 2,31 & $-0,12$ & 0,12 & 0,23 & $-0,13$ & 0,74 & $-0,42$ & 0,40 & 0,49 & $-0,11$ \\
\hline $\mathrm{abr} / 01$ & 1,49 & 2,59 & 0,30 & 0,03 & 1,27 & 0,10 & 0,31 & $-0,11$ & 0,03 & 0,85 & $-0,89$ \\
\hline $\mathrm{mai} / 01$ & 0,97 & 0,24 & 0,68 & 0,52 & 1,64 & $-0,16$ & 0,96 & 0,13 & 0,73 & 0,94 & $-0,11$ \\
\hline jun/01 & 0,56 & $-0,45$ & 0,74 & 0,52 & 1,53 & $-0,01$ & 0,70 & 1,04 & 0,60 & 0,54 & 1,93 \\
\hline $\mathrm{jul} / 01$ & 1,29 & $-0,10$ & 0,67 & 0,40 & 3,62 & 0,33 & 0,67 & 0,69 & 0,32 & 0,54 & 3,33 \\
\hline $\mathrm{ago} / 01$ & 1,01 & 0,78 & 1,06 & 0,35 & 1,11 & 0,13 & 1,66 & 0,43 & $-0,20$ & 0,20 & 1,11 \\
\hline set/01 & 0,44 & 0,66 & 1,27 & 0,30 & 0,66 & 0,19 & $-0,06$ & 0,24 & $-0,29$ & $-0,58$ & 0,44 \\
\hline out $/ 01$ & 1,64 & 0,68 & 1,10 & 0,27 & 0,94 & 1,19 & $-0,14$ & 0,61 & $-0,49$ & 0,39 & 1,71 \\
\hline nov/01 & 1,88 & 0,65 & 1,09 & 0,17 & 1,05 & 1,20 & 0,37 & 0,89 & 0,15 & 0,52 & 0,36 \\
\hline $\operatorname{dez} / 01$ & 0,56 & 1,06 & 1,54 & 0,15 & 0,59 & 1,33 & 0,34 & 1,91 & 0,94 & 0,73 & 0,59 \\
\hline $\mathrm{jan} / 02$ & 0,43 & 1,86 & 1,47 & $-0,17$ & 5,58 & 1,04 & 1,22 & 0,55 & 0,48 & 0,39 & $-2,87$ \\
\hline fev/02 & 0,08 & 0,58 & 0,85 & 0,16 & 0,19 & 0,69 & 0,34 & $-0,67$ & 0,26 & 0,64 & $-1,21$ \\
\hline $\mathrm{mar} / 02$ & 0,03 & 1,44 & 0,78 & 0,26 & 1,49 & $-0,19$ & 0,66 & 0,00 & $-0,05$ & 0,82 & 1,51 \\
\hline $\mathrm{abr} / 02$ & $-0,58$ & 0,25 & 0,69 & 0,32 & 2,38 & $-0,04$ & 0,31 & 1,05 & 0,27 & 1,39 & 2,89 \\
\hline mai/02 & $-0,61$ & $-0,10$ & 0,58 & 0,16 & 0,32 & 0,82 & 0,94 & 1,39 & $-0,30$ & 1,01 & 0,29 \\
\hline jun/02 & 0,27 & 0,06 & 0,53 & 0,15 & 1,91 & 0,08 & $-0,16$ & 1,39 & $-0,67$ & $-0,52$ & 0,99 \\
\hline jul/02 & 1,14 & 0,98 & 0,16 & 0,42 & 3,11 & 0,20 & 0,43 & 0,91 & $-0,29$ & 0,63 & 0,80 \\
\hline $\mathrm{ago} / 02$ & 2,93 & 0,42 & 1,02 & & 0,49 & 0,67 & 0,50 & 0 & $-0,16$ & 0,20 & $-0,27$ \\
\hline set/02 & 2,74 & 0,75 & 1,52 & $-0,12$ & $-0,88$ & 1,80 & 0,82 & 0,55 & 0,11 & 0,75 & 0,27 \\
\hline out/02 & 3,82 & 1,12 & 1,73 & 0,00 & 0,31 & 2,53 & $-0,82$ & 1,22 & $-0,59$ & 0,03 & 2,23 \\
\hline nov/02 & 7,02 & 3,97 & 2,04 & 0,25 & 3,34 & 2,95 & 2,01 & 0,97 & 1,90 & 0,80 & 7,01 \\
\hline $\operatorname{dez} / 02$ & 4,25 & 3,61 & 3,31 & 0,30 & 1,94 & 2,13 & 2,02 & 0,93 & 1,58 & $-0,38$ & 1,86 \\
\hline $\mathrm{jan} / 03$ & 1,61 & 3,26 & 2,83 & 0,59 & 2,43 & 1,96 & 1,22 & 0,94 & 1,59 & 0,78 & 6,18 \\
\hline fev/03 & 0,84 & 2,10 & 2,16 & 0,41 & $-0,29$ & 1,65 & 0,52 & 0,11 & 0,24 & $-0,11$ & 4,82 \\
\hline $\mathrm{mar} / 03$ & 1,03 & 3,46 & 3,08 & 0,50 & 1,19 & 1,17 & 1,47 & 0,60 & 0,74 & $-0,31$ & 0,99 \\
\hline $\mathrm{abr} / 03$ & 0,75 & 1,61 & 2,56 & 0,28 & 3,03 & 0,88 & $-0,04$ & 1,03 & 1,05 & 0,03 & 0,49 \\
\hline $\mathrm{mai} / 03$ & 1,44 & $-0,28$ & 1,08 & 0,49 & 3,69 & 0,25 & 0,74 & 1,14 & 0,15 & 0,57 & $-0,73$ \\
\hline jun/03 & 0,30 & $-1,31$ & 0,43 & 0,90 & 0,29 & 0,00 & $-0,41$ & 1,89 & 0,09 & 0,44 & $-2,47$ \\
\hline $\mathrm{jul} / 03$ & $-0,41$ & $-0,97$ & 0,33 & 0,46 & 1,11 & 0,01 & $-1,26$ & 0,35 & 0,32 & 0,81 & $-1,44$ \\
\hline $\mathrm{ago} / 03$ & 0,03 & $-0,68$ & 0,12 & 0,20 & 1,68 & 0,04 & 0,88 & 0,09 & $-0,55$ & 0,54 & 0,18 \\
\hline set/03 & 1,14 & 0,21 & 0,12 & 0,65 & 1,68 & 0,23 & 0,40 & 0,72 & $-0,41$ & 0,15 & 1,18 \\
\hline out $/ 03$ & 0,77 & 0,05 & $-0,12$ & 0,39 & 0,57 & 0,48 & 0,35 & 0,92 & $-0,60$ & $-0,32$ & $-0,35$ \\
\hline nov/03 & 0,11 & 0,79 & 0,17 & 0,55 & 0,15 & 0,06 & 0,96 & 0,99 & $-0,09$ & 0,47 & 0,12 \\
\hline $\mathrm{dez} / 03$ & 0,24 & 0,67 & 0,31 & 0,41 & 0,09 & 0,12 & 0,16 & 0,98 & 0,34 & 0,82 & 0,72 \\
\hline $\mathrm{jan} / 04$ & 0,44 & 1,89 & 0,60 & 0,66 & 1,57 & 0,34 & 0,76 & 0,04 & 1,50 & 0,95 & 0,53 \\
\hline fev/04 & $-0,38$ & 1,33 & $-0,19$ & 0,23 & 0,41 & 0,38 & 1,00 & $-0,22$ & 1,39 & 1,70 & $-0,12$ \\
\hline $\mathrm{mar} / 04$ & 0,12 & 1,34 & 0,58 & & & 0,68 & 0,88 & 0,46 & 2,03 & 1,15 & $-1,12$ \\
\hline $\mathrm{abr} / 04$ & $-0,39$ & $-0,08$ & 0,63 & 0,17 & 1,27 & 0,29 & 0,58 & 1,11 & 0,76 & 0,93 & $-0,35$ \\
\hline mai/04 & 0,28 & 0,43 & 0,92 & 0,28 & 0,78 & 0,29 & 0,33 & 1,34 & 1,18 & 1,36 & 0,06 \\
\hline jun/04 & 0,93 & 0,59 & 0,54 & 0,24 & 0,12 & 0,66 & 0,30 & 1,14 & 1,30 & 0,44 & 2,07 \\
\hline jul/04 & 0,81 & 0,57 & 0,56 & 0,28 & 2,01 & 0,49 & $-0,36$ & 0,51 & 0,60 & 0,65 & 1,29 \\
\hline $\mathrm{ago} / 04$ & 0,29 & 2,06 & 0,68 & 0,46 & 0,21 & $-0,06$ & 0,28 & 0,50 & 0,76 & 0,63 & 1,54 \\
\hline set/04 & 0,24 & $-0,88$ & 0,81 & $-0,21$ & 0,54 & 0,74 & 0,00 & 0,96 & 1,07 & 1,08 & $-0,09$ \\
\hline out $/ 04$ & $-0,10$ & $-0,21$ & 0,70 & 0,44 & 0,44 & 0,57 & $-0,49$ & 1,12 & 1,21 & 0,36 & 1,12 \\
\hline nov/04 & 0,02 & $-0,04$ & 0,75 & 0,57 & 0,17 & 0,54 & 0,44 & 1,02 & 0,83 & 1,35 & 2,16 \\
\hline $\mathrm{dez} / 04$ & 0,66 & 0,91 & 0,65 & 0,47 & 0,49 & 0,40 & 1,28 & 1,59 & 0,51 & 0,45 & 2,49 \\
\hline
\end{tabular}

Economia e Sociedade, Campinas, v. 22, n. 2 (48), p. 409-456, ago. 2013. 
Thiago Sevilhano Martinez / Vinícius dos Santos Cerqueira

Continuação

\begin{tabular}{|c|c|c|c|c|c|c|c|c|c|c|c|}
\hline \\
\hline \multicolumn{9}{|c|}{ Grupos do IPCA } & \multicolumn{3}{|c|}{ Tipo de precificação } \\
\hline \multicolumn{3}{|c|}{ 1.Alimentação e bebidas } & \multicolumn{3}{|c|}{ 4.Vestuário } & \multicolumn{3}{|c|}{ 7.Despesas pessoais } & \multicolumn{3}{|c|}{ c. Comercializáveis } \\
\hline \multicolumn{3}{|c|}{ 2.Habitação } & 5.Tran & ortes & & 8.Edu & & & nc. Não-cc & rcializáv & \\
\hline 3.Ar & s de resi & & 6.Saúd & e cuidad & pessoais & 9.Con & nicação & & m. Monito & & \\
\hline & 6.c & $6 . \mathrm{nc}$ & $6 . \mathrm{m}$ & $7 . c$ & 7.nc & $7 . \mathrm{m}$ & 8.c & 8.nc & 9.c & 9.nc & $9 . \mathrm{m}$ \\
\hline ago/99 & 1,48 & 0,18 & 0,12 & $-0,63$ & 0,04 & 0,00 & 0,35 & 0,40 & 0,01 & 0,00 & 0,00 \\
\hline set/99 & 0,46 & 0,74 & 1,21 & 0,05 & $-0,15$ & 0,00 & 0,59 & 0,05 & 0,02 & 0,00 & $-0,25$ \\
\hline out/99 & 0,47 & 0,24 & 0,36 & 0,40 & 0,12 & $-0,01$ & 1,25 & $-0,05$ & 0,01 & 0,00 & $-0,06$ \\
\hline nov/99 & 0,37 & 0,20 & 0,14 & 0,10 & 0,02 & 0,00 & 3,58 & 0,02 & 0,10 & 3,19 & $-0,09$ \\
\hline $\mathrm{dez} / 99$ & 0,20 & $-0,29$ & 0,36 & 0,48 & 0,30 & 0,03 & $-0,03$ & 0,48 & $-3,25$ & $-2,54$ & 0,00 \\
\hline $\mathrm{jan} / 00$ & 0,69 & 0,22 & 0,62 & 0,38 & 0,03 & $-0,05$ & 2,30 & 3,08 & $-0,62$ & 7,40 & 81 \\
\hline fev $/ 00$ & 0,24 & 0,28 & 0,13 & 0,71 & 0,25 & 0,18 & $-0,04$ & 1,38 & 32 & 0,89 &, 02 \\
\hline $\mathrm{mar} / 00$ & 0,18 & 0,38 & 0,44 & $-0,16$ & $-0,05$ & 0,10 & 2,23 & $-0,36$ & $-1,01$ & 0,00 & 0,08 \\
\hline $\mathrm{abr} / 00$ & $-0,07$ & 0,14 & 0,37 & $-0,08$ & 5,14 & $-0,10$ & $-0,88$ & 0,05 &, 41 & 0,70 & $-0,30$ \\
\hline $\mathrm{mai} / 00$ & 0,05 & 0,12 & $-0,12$ & 0,31 & 0,08 & $-0,17$ & 1,16 & 0,02 &, 23 & 2,05 & 0,17 \\
\hline jun/00 & 0,89 & $-0,05$ & $-0,32$ & $-0,12$ & 0,28 & $-2,98$ & 1,11 & $-0,24$ & $-1,30$ & 3,01 & 2,70 \\
\hline $\mathrm{jul} / 00$ & 0,45 & 0,43 & 0,58 & 0,06 & 0,25 & 0,09 & 0,42 & $-0,28$ & 2,25 & $-0,67$ & 7,69 \\
\hline ago/00 & 0,00 & 0,22 & 3,65 & 0,29 & 0,36 & $-0,13$ & 0,89 & 0,17 & $-0,13$ & $-2,26$ & $-0,03$ \\
\hline set/00 & $-0,19$ & 0,01 & 0,00 & 0,27 & 0,16 & 0,00 & $-0,42$ & 0,29 & $-1,71$ & 1,05 & 0,20 \\
\hline out/00 & $-0,15$ & 0,15 & 0,00 & 0,27 & 0,13 & 0,13 & 0,97 & 0,07 &, 79 & 4,81 & 0,02 \\
\hline nov/00 & $-0,21$ & 0,08 & 0,00 & 0,14 & 0,05 & 0,07 & $-0,28$ & 0,23 &, 49 & 0,66 & 0,10 \\
\hline $\mathrm{dez} / 00$ & $-0,26$ & 0,36 & 0,00 & 0,44 & 0,52 & 0,19 & 1,87 & 0,14 & $-2,22$ & 1,28 & 0,05 \\
\hline $\mathrm{jan} / 01$ & 0,18 & 0,39 & 0,00 & 0,44 & 0,36 & 0,32 & $-0,13$ & 1,48 & 78 & 0,94 & 0,32 \\
\hline fev/01 & 1,16 & 0,24 & 0,00 & 0,00 & 0,24 & 0,25 & 1,36 & 2,95 & 57 & $-0,23$ & 0,15 \\
\hline $\mathrm{mar} / 01$ & 1,09 & -0 & 0,00 & 0,35 & & 010 & & 0,49 & & & 0,08 \\
\hline $\mathrm{abr} / 01$ & 0,2 & 0 , & 0,00 & 0 , & & 9 & & 57 & 2 & &, 00 \\
\hline $\mathrm{mai} / 01$ & & & & & & & & & & &, 03 \\
\hline jun/01 & & & & & & 0,6 & $-0,73$ & 18 & & & 18 \\
\hline $\mathrm{jul} / 01$ & & & & & & & 2,67 & 10 & & & 48 \\
\hline ago/01 & 0,93 & & 0 & 0 & & 3 & 0,48 & 14 & 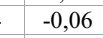 & &, 38 \\
\hline set/01 & 0 & & & & & & 1,55 & 34 & 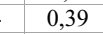 & & $-0,15$ \\
\hline out/01 & & & & & & 0, & $-1,60$ & 08 & & & 0,04 \\
\hline nov/01 & $x^{2}$ & & 0,7 & 2 , & 0 & 0,1 & 0,79 & 29 & 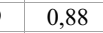 & 0 &, 03 \\
\hline $\mathrm{dez} / 01$ & 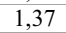 & & 0,68 & 0, & 0,09 & 0 & 0,46 & 11 & & 0,00 & $-0,05$ \\
\hline $\mathrm{jan} / 02$ & 0 , & & 0,31 & 0 & 47 & s & 0,99 & 38 & & 0,00 &, 43 \\
\hline fev/02 & 1 & 4 & 0,70 & 0, & 77 & 0,48 & 0,46 & 89 & 4 & 0,00 & 40 \\
\hline $\mathrm{mar} / 02$ & 1,87 & 0,13 & 0,70 & 0,21 & $-0,40$ & $-0,57$ & $-0,60$ & 71 & 64 & 0,63 & 01 \\
\hline $\mathrm{abr} / 02$ & 0,70 & 0,53 & 1,08 & 0,21 & 0,69 & 0,07 & 0,37 & 38 &, 75 & 0,64 &, 02 \\
\hline $\mathrm{mai} / 02$ & $-0,04$ & 017 & 0,69 & 0,12 & 0,92 & 0,01 & 1,06 & 42 & ,78 & 1,58 &, 00 \\
\hline jun/02 & 0,02 & 0,33 & 0,69 & $-0,48$ & 0,58 & 0,16 & $-0,05$ & 0,19 & 24 & 0,45 &, 22 \\
\hline $\mathrm{jul} / 02$ & 0,57 & 0,19 & 0,68 & $-0,08$ & 1,47 & 0,22 & $-0,09$ & 0,13 & $-1,95$ & 0,78 &, 43 \\
\hline ago/02 & 0,29 & 1,04 & 0,65 & 0,48 & 0,58 & $-0,09$ & 1,01 & 0,26 & $-0,47$ & 0,28 & 0,47 \\
\hline set/02 & 0,42 & 134 & 0,66 & 0,87 & & 0,80 & 1,00 & 0,38 & 0,63 & 0,31 & 0,10 \\
\hline out/02 & 0,66 & 0,51 & 0,65 & 3,03 & 47 & 0,39 & 0,38 & 0,13 &, 13 & 0,35 & 0,05 \\
\hline nov/02 & 0,90 & & 0,65 & 0,66 & & 0,09 & 1,72 & 0,18 & 3,23 & 0,43 & 0,01 \\
\hline $\operatorname{dez} / 02$ & 4,16 & 0,87 & 0,65 & 5,70 & 0,97 & 0,25 & 0,90 & 0,25 & 2,74 & 0,54 & 0,02 \\
\hline $\mathrm{jan} / 03$ & 2,06 & 0,35 & 0,65 & 2,36 & & 7,78 & 2,46 & 1,17 & 1,36 & 6,56 & 0,28 \\
\hline fev/03 & 0,68 & 0,64 & 0,66 & 0,40 & & 4,07 & 1,50 & 5,82 & 4,11 & 6,66 & 3,21 \\
\hline $\mathrm{mar} / 03$ & 3,72 & & 0,6 & 0,89 & & 7 & 1,82 & 0,88 & 1 & $-1,34$ & 1,60 \\
\hline $\mathrm{abr} / 03$ & 2,24 & & 0,6 & 0,3 & & 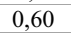 & 0,92 & 0,41 & 1 & $-5,60$ & 0,16 \\
\hline $\mathrm{mai} / 03$ & & & & & & & & & & & 03 \\
\hline jun/03 & & & & & & & & & & & 20 \\
\hline $\mathrm{jul} / 03$ & & & & & & & & & & & 42 \\
\hline ago/03 & & & & & & & & & & & 0 \\
\hline set/03 & 0,45 & & & 1,2 & & 0,00 & & & & & 4 \\
\hline out/03 & 0,60 & & 07 & 0,53 & & 0,00 & $-0,70$ & 0,00 & & 0,49 & $-0,06$ \\
\hline nov/03 & $-0,18$ & & 7 & 1,60 & 2 & 6,78 & 1,39 & 0,09 & - & 0,42 & 0,03 \\
\hline $\mathrm{dez} / 03$ & 0,3 & & 7 & 2,77 & 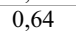 & 251 & 1,12 & 0,14 & $-0,36$ & 0,30 & 0,06 \\
\hline $\mathrm{jan} / 04$ & 0,37 & 19 & 0,76 & 1,27 &, 83 & 1,20 & 2,86 & 0,58 & $-0,54$ & 3,01 & 0,16 \\
\hline fev/04 & $-0,09$ & 0,98 & 0,75 & 1,22 &, 03 & 0,55 & $-0,27$ & 7,02 & $-2,31$ & 1,95 & 0,84 \\
\hline $\mathrm{mar} / 04$ & 0,76 & 0,66 & 0,75 & 2,47 &, 48 & 0,08 & 0,55 & 0,62 & 0,21 & 0,19 & 0,72 \\
\hline $\mathrm{abr} / 04$ & 2,28 & 0,32 & 0,75 & 0,35 & 0,29 & 0,17 & 0,41 & 0,40 &, 59 & 0,16 & $-0,02$ \\
\hline $\mathrm{mai} / 04$ & 1,68 & 0,38 & 0,74 & 0,19 & 0,04 & $-0,06$ & 0,94 & 0,22 & 0,57 & 2,55 & 0,04 \\
\hline jun/04 & 0,29 & 0,45 & 0,74 & 0,25 & 0,33 & 0,04 & 1,21 & 0,15 & 1,23 & 0,22 & 0,06 \\
\hline $\mathrm{jul} / 04$ & 0,36 & 0,31 & 0,91 & $-0,26$ & 0,83 & 0,14 & 0,31 & 0,27 & 0,17 & 0,30 & 4,50 \\
\hline ago/04 & 0,23 & 0,43 & 0,92 & $-0,07$ & 0,97 & 0,26 & 0,88 & 0,56 & 0,66 & 1,00 & 0,63 \\
\hline set/04 & $-0,48$ & 0,47 & 0,92 & 0,42 & 0,47 & 0,63 & $-0,08$ & 0,14 & $-0,61$ & 0,34 & 2,85 \\
\hline out/04 & 0,26 & 0,16 & 0,92 & 0,60 & 0,69 & $-0,66$ & 0,78 & $-0,11$ & 0,02 & 0,33 & 0,69 \\
\hline /04 & 0,06 & 0,34 & 0,92 & 2,04 & $-0,09$ & $-0,04$ & 1,31 & 0,03 & 0,47 & 0,72 & 2,39 \\
\hline 04 & 0,00 & 0,75 & 0,96 & 0,79 & 0,90 & 0,95 & 1,61 & 0,27 & $-1,23$ & 0,34 & - \\
\hline
\end{tabular}


Classificação do IPCA por Segmentos - Inflação (jan/05 - dez/09)

\begin{tabular}{|c|c|c|c|c|c|c|c|c|c|c|c|}
\hline \multicolumn{8}{|c|}{ Grupos do IPCA } & \multicolumn{4}{|c|}{ Tipo de precificação } \\
\hline \multicolumn{3}{|c|}{ 1.Alimentação e bebidas } & \multicolumn{3}{|c|}{ 4.Vestuário } & \multicolumn{2}{|c|}{ 7.Despesas pessoais } & \multicolumn{4}{|c|}{ c. Comercializáveis } \\
\hline \multicolumn{3}{|c|}{ 2.Habitação } & \multicolumn{3}{|c|}{ 5.Transportes } & \multicolumn{2}{|c|}{ 8.Educação } & \multicolumn{4}{|c|}{ nc. Não-comercializáveis } \\
\hline \multicolumn{3}{|c|}{ 3.Artigos de residência } & 6.Saúd & cuidad & pessoais & 9. Com & cação & & Monitora & & \\
\hline & 1.c & $1 . \mathrm{nc}$ & 2.c & $2 . \mathrm{nc}$ & $2 . \mathrm{m}$ & 3.c & $3 . \mathrm{nc}$ & 4.c & 5.c & $5 . \mathrm{nc}$ & $5 . \mathrm{m}$ \\
\hline $\mathrm{jan} / 05$ & 0,35 & 1,77 & 0,97 & 0,36 & 0,67 & 0,89 & 0,16 & 0,23 & 1,16 & 0,67 & 0,41 \\
\hline $\mathrm{fev} / 05$ & $-0,28$ & 2,02 & 1,01 & 0,43 & 0,36 & 0,58 & 1,40 & $-0,22$ & 0,31 & 0,63 & $-0,09$ \\
\hline $\mathrm{mar} / 05$ & 0,05 & 0,82 & 1,19 & 0,62 & 0,94 & 0,17 & 0,31 & 0,60 & 0,30 & 0,38 & 1,96 \\
\hline $\mathrm{abr} / 05$ & 0,80 & 0,92 & 0,33 & 0,28 & 1,24 & 0,53 & 0,42 & 0,92 & 0,74 & 0,90 & 1,24 \\
\hline $\mathrm{mai} / 05$ & 0,50 & 1,24 & 0,78 & 0,14 & 0,94 & 0,59 & 0,45 & 1,45 & 0,13 & 0,36 & $-0,22$ \\
\hline jun/05 & $-0,58$ & $-0,61$ & 0,46 & 0,27 & 0,35 & 0,16 & 0,26 & 0,38 & 0,60 & 1,01 & $-0,97$ \\
\hline jul/05 & $-0,93$ & $-0,30$ & 0,18 & 0,28 & $-0,13$ & 0,25 & 0,26 & 0,15 & 0,08 & 1,02 & 0,66 \\
\hline ago/05 & $-0,66$ & $-0,70$ & $-0,17$ & 0,40 & 0,50 & 0,23 & 0,51 & 0,05 & $-0,03$ & 0,08 & 0,65 \\
\hline set/05 & $-0,15$ & $-0,36$ & 0,18 & 0,57 & 0,70 & $-0,30$ & 0,19 & 0,19 & $-0,29$ & 0,33 & 1,38 \\
\hline out/05 & 0,73 & $-0,39$ & 0,36 & 0,51 & 0,44 & $-0,40$ & $-0,03$ & 0,72 & 0,38 & 1,19 & 3,08 \\
\hline nov $/ 05$ & 0,31 & 2,25 & 0,03 & 0,36 & 0,90 & $-0,58$ & 0,90 & 0,85 & $-0,13$ & 0,10 & 1,06 \\
\hline $\mathrm{dez} / 05$ & $-0,11$ & 1,22 & 0,22 & 0,36 & 0,48 & 0,39 & $-0,03$ & 1,58 & $-0,01$ & $-0,69$ & 0,61 \\
\hline $\mathrm{jan} / 06$ & $-0,70$ & 1,87 & 0,30 & 0,45 & $-0,33$ & 0,62 & 0,42 & 0,03 & 3,08 & 0,64 & 1,20 \\
\hline fev/06 & $-0,25$ & $-0,17$ & $-0,10$ & 0,61 & 0,21 & $-0,52$ & 1,23 & $-0,54$ & 0,83 & 1,03 & 0,64 \\
\hline $\mathrm{mar} / 06$ & $-0,50$ & 0,45 & $-0,17$ & 0,35 & 0,83 & $-0,10$ & $-0,73$ & 0,21 & 2,94 & $-0,23$ & 0,87 \\
\hline $\mathrm{abr} / 06$ & $-0,65$ & 0,64 & 0,22 & 0,44 & 0,72 & $-0,86$ & 1,00 & 1,18 & $-0,09$ & 0,08 & $-0,01$ \\
\hline $\mathrm{mai} / 06$ & 0,49 & $-0,74$ & 0,02 & 0,33 & 0,38 & & 0,20 & 0,90 & & 0,23 & 0,23 \\
\hline jun/06 & $-0,13$ & $-1,29$ & $-0,02$ & 0,15 & 0,63 & $-0,70$ & 0,19 & 0,59 & -2 & 0,03 & $-0,59$ \\
\hline jul/06 & 0,16 & 0,01 & $-0,13$ & 0,30 & $-0,28$ & 0,00 & 0,27 & $-0,24$ & $-0,17$ & $-0,24$ & 0,79 \\
\hline ago/06 & 0,15 & $-0,03$ & $-0,24$ & 0,21 & 0,08 & $-0,16$ & 0,05 & 0,09 & $-0,55$ & $-0,46$ & $-0,18$ \\
\hline set/06 & 0,33 & $-0,22$ & $-0,25$ & 0,38 & 0,57 & $-0,15$ & $-0,06$ & 0,46 & $-0,30$ & 0,32 & 0,00 \\
\hline out/06 & 0,83 & 0,94 & $-0,15$ & 0,26 & 0,20 & $-0,43$ & $-0,23$ & 0,65 & $-0,09$ & $-0,41$ & $-0,06$ \\
\hline nov/06 & 0,97 & 1,15 & $-0,08$ & 0,18 & $-0,30$ & 0,04 & $-0,36$ & 0,65 & 0,03 & $-0,49$ & $-0,01$ \\
\hline $\mathrm{dez} / 06$ & 0,40 & 0,36 & 0,09 & 0,45 & $-0,02$ & $-0,20$ & 0,02 & 1,00 & 0,31 & $-0,05$ & 1,85 \\
\hline $\mathrm{jan} / 07$ & 0,28 & 1,53 & 0,71 & 0,69 & $-0,58$ & 0,36 & $-0,35$ & $-0,19$ & 0,51 & 0,62 & 0,65 \\
\hline fev/07 & 0,20 & 1,48 & 0,26 & 0,47 & $-0,06$ & $-0,43$ & $-0,68$ & $-0,72$ & 0,01 & $-0,38$ & 0,25 \\
\hline $\mathrm{mar} / 07$ & 0,32 & 1,76 & 0,06 & 0,59 & $-0,01$ & $-0,32$ & $-1,27$ & 0,47 & 0,14 & $-0,07$ & 0,35 \\
\hline $\mathrm{abr} / 07$ & 0,18 & $-0,14$ & 0,67 & 0,31 & 0,42 & $-0,16$ & $-0,36$ & 0,33 & 0,54 & 0,12 & 0,29 \\
\hline $\mathrm{mai} / 07$ & 0,69 & $-0,48$ & 0,57 & & & & & 0,68 & & 0,00 & 0,29 \\
\hline jun/07 & 1,48 & & 0,12 & & & & & 0,91 & -1 & $-0,08$ & $-0,26$ \\
\hline jul/07 & 2,69 & $-0,45$ & & & & & & $-0,16$ & -0 & &, 03 \\
\hline ago/07 & 1,98 & 0,66 & 0,27 & 0,35 & $-0,25$ & 0,15 & $-0,63$ & $-0,03$ & $-0,04$ & 0,58 & $-0,08$ \\
\hline set/07 & 0,35 & 0,56 & 0,06 & 0,83 & 0,35 & 0,18 & 0,04 & 0,45 & 0,27 & $-0,59$ & $-0,18$ \\
\hline out $/ 07$ & $-0,70$ & 2,05 & $-0,17$ & 0,75 & $-0,71$ & 0,10 & 0,02 & 0,72 & 0,07 & $-0,13$ & 0,22 \\
\hline nov/07 & 0,28 & 1,27 & $-0,14$ & 0,84 & 0,11 & $-0,49$ & $-0,19$ & 0,55 & 0,51 & 0,41 & 0,32 \\
\hline $\mathrm{dez} / 07$ & 1,79 & 2,39 & 0,10 & 0,60 & $-0,24$ & $-0,48$ & 0,07 & 0,71 & 1,24 & 0,08 & 0,71 \\
\hline jan/08 & 0,63 & 2,59 & 0,25 & 0,51 & $-0,19$ & 0,11 & 0,65 & $-0,08$ & 0,25 & 0,52 & 0,42 \\
\hline $\mathrm{fev} / 08$ & 0,23 & 1,04 & 0,05 & 0,37 & 0,07 & $-0,07$ & $-0,52$ & $-0,54$ & 0,12 & 0,62 & $-0,14$ \\
\hline $\mathrm{mar} / 08$ & 0,94 & 0,84 & 0,23 & 0,26 & 1,09 & $-0,44$ & 0,19 & 0,75 & 0,21 & 0,63 & 0,43 \\
\hline $\mathrm{abr} / 08$ & 1,70 & 0,81 & 1,05 & 0,44 & $-0,18$ & 0,30 & 0,54 & 1,53 & $-0,11$ & $-0,27$ & 0,04 \\
\hline $\mathrm{mai} / 08$ & 2,79 & 0,95 & 1,62 & 0,41 & 0,02 & 0,14 & 0,50 & 0,98 & 0,41 & 0,44 & 0,26 \\
\hline jun/08 & 2,54 & & 1,0 & & & & & 0,41 & 7 & 0,53 & 0,21 \\
\hline jul/08 & 0,99 & 1,12 & 0,90 & 0,36 & & -0 & & $-0,02$ & & 1 & 0,66 \\
\hline ago/08 & $-0,12$ & $-0,25$ & 0,80 & 0,56 & 0,97 & 0,16 & 0,80 & 0,39 & 0,18 & 0,20 & $-0,04$ \\
\hline set/08 & $-0,32$ & $-0,20$ & 1,64 & 0,78 & 0,03 & 0,32 & 0,87 & 0,70 & $-0,15$ & 1,24 & 0,32 \\
\hline out/08 & 0,77 & 0,60 & 0,71 & 0,76 & 0,48 & 0,37 & 0,74 & 1,27 & $-0,03$ & $-0,11$ & 0,08 \\
\hline nov $/ 08$ & 0,91 & 0,23 & 0,82 & 0,70 & 0,09 & 0,62 & 1,25 & 0,71 & $-0,11$ & $-0,58$ & 0,20 \\
\hline $\mathrm{dez} / 08$ & 0,06 & 0,74 & 0,76 & 0,43 & 0,04 & $-0,04$ & $-0,03$ & 0,99 & $-1,13$ & $-0,67$ & 0,59 \\
\hline jan/09 & 0,26 & 1,34 & 0,57 & 0,96 & 0,02 & 0,56 & $-0,60$ & 0,05 & $-1,88$ & $-1,00$ & 1,58 \\
\hline fev/09 & $-0,10$ & 0,73 & 0,61 & 0,67 & $-0,29$ & 0,08 & 2,14 & $-0,24$ & $-0,41$ & $-0,24$ & 0,61 \\
\hline $\mathrm{mar} / 09$ & $-0,22$ & 0,92 & 0,31 & 0,32 & 0,17 & 0,55 & $-0,19$ & 0,70 & $-0,47$ & 0,07 & 0,02 \\
\hline $\mathrm{abr} / 09$ & 0,01 & 0,31 & 0,29 & 0,50 & 1,07 & $-0,60$ & 0,40 & 1,08 & $-0,69$ & 0,08 & $-0,12$ \\
\hline $\mathrm{mai} / 09$ & 1,00 & $-0,21$ & 0,41 & 0,61 & 0,89 & $-0,05$ & 1,03 & 1,16 & $-0,62$ & 0,32 & $-0,19$ \\
\hline jun/09 & 1,32 & $-0,04$ & & 0,47 & & 0,82 & 0,95 & 0,53 & $-0,45$ & $-0,43$ & 0,31 \\
\hline $\mathrm{jul} / 09$ & 0,18 & $-0,36$ & 0,01 & 0,42 & 1,98 & 0,50 & $-0,86$ & $-0,01$ & 0,14 & $-0,22$ & 0,25 \\
\hline ago/09 & $-0,89$ & 1,05 & $-0,33$ & 0,37 & 0,69 & $-0,24$ & $-0,26$ & 0,13 & 0,31 & $-0,53$ & $-0,12$ \\
\hline set/09 & $-0,50$ & 0,30 & $-0,03$ & 0,49 & 0,86 & $-0,07$ & 0,31 & 0,58 & 0,57 & 0,52 & 0,09 \\
\hline out $/ 09$ & $-0,26$ & 0,12 & $-0,58$ & 0,07 & 0,64 & 0,37 & 0,50 & 0,64 & 1,61 & 0,29 & 0,21 \\
\hline nov/09 & $-0,28$ & 1,60 & 0,10 & 0,08 & 0,31 & 0,42 & 0,48 & 0,58 & 0,91 & 0,04 & 0,68 \\
\hline $\operatorname{dez} / 09$ & $-0,20$ & 0,75 & $-0,08$ & 0,52 & $-0,12$ & 0,50 & 0,57 & 0,76 & 0,23 & 0,13 & 1,16 \\
\hline
\end{tabular}

Continua... 
Thiago Sevilhano Martinez / Vinícius dos Santos Cerqueira

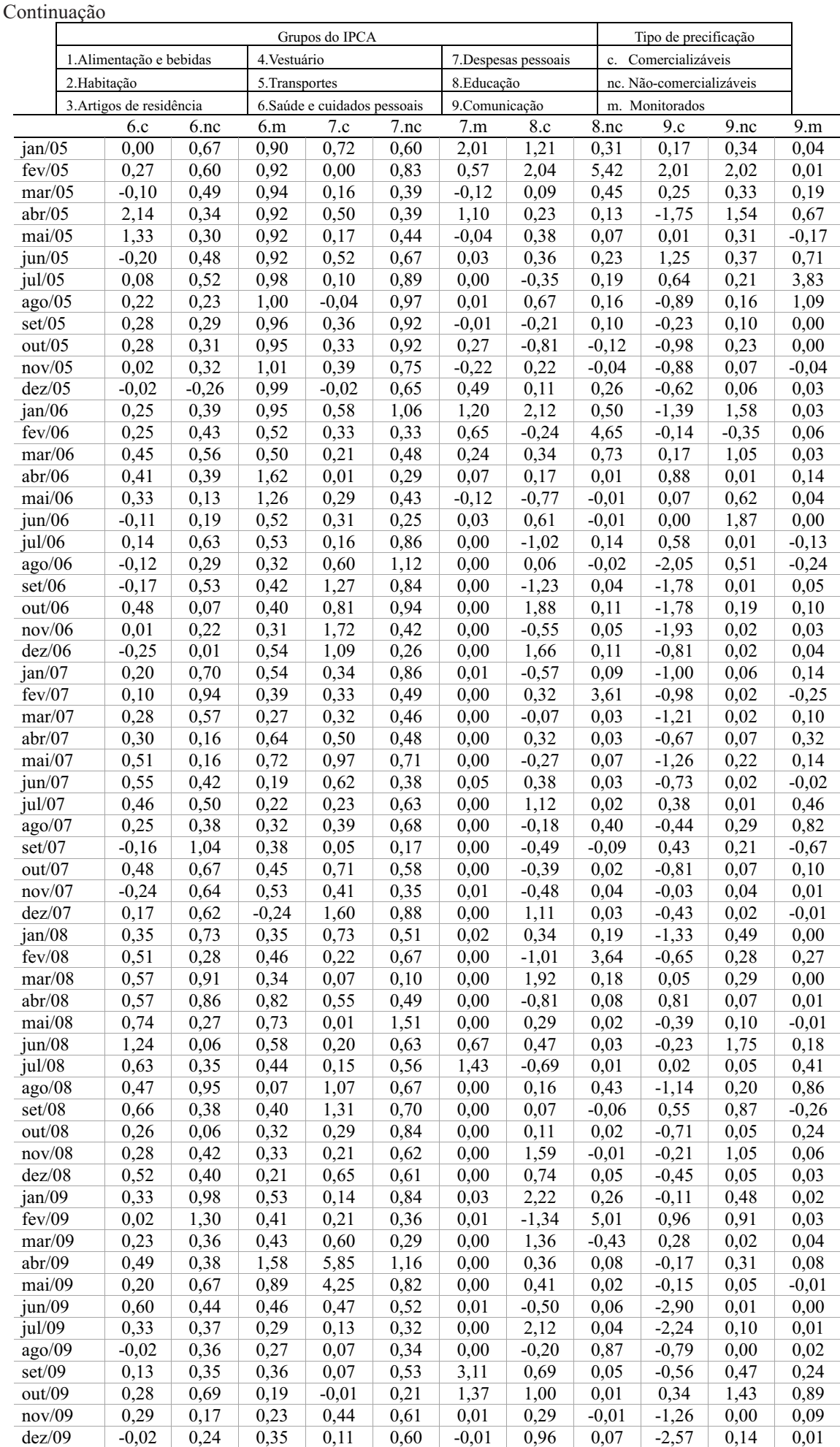


Estrutura da inflação brasileira: determinantes e desagregação do IPCA

Classificação do IPCA por Segmentos - Pesos (ago/99 - dez/04)

\begin{tabular}{|c|c|c|c|c|c|c|c|c|c|c|c|}
\hline \multicolumn{9}{|c|}{ Grupos do IPCA } & \multicolumn{3}{|c|}{ Tipo de precificação } \\
\hline \multicolumn{3}{|c|}{ 1.Alimentação e bebidas } & \multicolumn{3}{|c|}{ 4.Vestuário } & \multicolumn{3}{|c|}{ 7.Despesas pessoais } & \multicolumn{3}{|c|}{ c. Comercializáveis } \\
\hline \multicolumn{3}{|c|}{ 2.Habitação } & \multicolumn{3}{|c|}{ 5.Transportes } & 8.Ed & & & nc. Não-co & cializá & \\
\hline & gos de res & ncia & 6.Sa & e cuida & pessoais & $9 . \mathrm{Co}$ & nicação & & m. Monito & & \\
\hline & $1 . c$ & 1.nc & 2.c & 2.nc & $2 . \mathrm{m}$ & 3.c & $3 . n c$ & $4 . c$ & $5 . c$ & $5 . \mathrm{nc}$ & $5 . \mathrm{m}$ \\
\hline ago/99 & 13,56 & 8,73 & 1,32 & 7,93 & 7,04 & 5,50 & 0,48 & 5,68 & 4,41 & 4,69 & 10,90 \\
\hline set/99 & 13,54 & 8,69 & 1,31 & 7,88 & 7,15 & 5,47 & 0,48 & 5,65 & 4,39 & 4,71 & 11,06 \\
\hline out/99 & 13,55 & 8,66 & 1,32 & 7,83 & 7,17 & 5,46 & 0,47 & 5,65 & 4,38 & 4,74 & 11,09 \\
\hline nov/99 & 13,78 & 8,56 & 1,31 & 7,71 & 7,10 & 5,43 & 0,46 & 5,64 & 4,75 & 4,75 & 11,12 \\
\hline $\operatorname{dez} / 99$ & 13,94 & 8,49 & 1,31 & 7,64 & 7,09 & 5,42 & 0,46 & 5,62 & 4,71 & 4,74 & 11,41 \\
\hline $\mathrm{jan} / 00$ & 14,10 & 8,51 & 1,31 & 7,59 & 7,11 & 5,43 & 0,46 & 5,62 & 4,69 & 4,68 & 11,44 \\
\hline fev $/ 00$ & 14,10 & 8,56 & 1,31 & 7,55 & 7,09 & 5,41 & 0,47 & 5,60 & 4,66 & 4,69 & 11,40 \\
\hline $\mathrm{mar} / 00$ & 14,03 & 8,54 & 1,32 & 7,54 & 7,07 & 5,44 & 0,45 & 5,55 & 4,71 & 4,75 & 11,35 \\
\hline $\mathrm{abr} / 00$ & 13,87 & 8,55 & 1,33 & 7,51 & 7,07 & 5,44 & 0,44 & 5,46 & 4,72 & 4,80 & 11,59 \\
\hline $\mathrm{mai} / 00$ & 13,74 & 8,51 & 1,34 & 7,46 & 7,05 & 5,43 & 0,44 & 5,48 & 4,74 & 4,84 & 11,55 \\
\hline jun/00 & 13,66 & 8,44 & 1,35 & 7,46 & 7,12 & 5,44 & 0,45 & 5,50 & 4,75 & 4,86 & 11,55 \\
\hline $\mathrm{jul} / 00$ & 13,74 & 8,33 & 1,34 & 7,42 & 7,12 & 5,45 & 0,45 & 5,53 & 4,74 & 4,89 & 11,48 \\
\hline ago/00 & 13,92 & 8,20 & 1,32 & 7,28 & 7,23 & 5,38 & 0,44 & 5,49 & 4,72 & 4,84 & 11,85 \\
\hline set/00 & 14,07 & 8,21 & 1,30 & 7,18 & 7,21 & 5,36 & 0,44 & 5,44 & 4,68 & 4,82 & 12,19 \\
\hline out $/ 00$ & 14,09 & 8,25 & 1,30 & 7,16 & 7,22 & 5,38 & 0,44 & 5,46 & 4,66 & 4,86 & 12,13 \\
\hline nov/00 & 14,02 & 8,33 & 1,30 & 7,15 & 7,22 & 5,39 & 0,44 & 5,49 & 4,65 & 4,89 & 12,09 \\
\hline $\mathrm{dez} / 00$ & 13,92 & 8,34 & 1,30 & 7,13 & 7,30 & 5,40 & 0,45 & 5,50 & 4,63 & 4,88 & 12,21 \\
\hline $\mathrm{jan} / 01$ & 13,77 & 8,25 & 1,29 & 7,09 & 7,40 & 5,40 & 0,44 & 5,52 & 4,61 & 4,80 & 12,59 \\
\hline fev/01 & 13,72 & 8,31 & 1,29 & 7,06 & 7,45 & 5,40 & 0,44 & 5,49 & 4,61 & 4,79 & 12,64 \\
\hline $\mathrm{mar} / 01$ & 13,61 & 8,33 & 1,29 & 7,04 & 7,46 & 5,39 & 0,44 & 5,43 & 4,61 & 4,82 & 12,68 \\
\hline $\mathrm{abr} / 01$ & 13,66 & 8,46 & 1,29 & 7,02 & 7,45 & 5,36 & 0,44 & 5,39 & 4,61 & 4,82 & 12,62 \\
\hline mai/01 & 13,78 & 8,60 & 1,28 & 6,99 & 7,50 & 5,33 & 0,44 & 5,35 & 4,59 & 4,83 & 12,44 \\
\hline jun/01 & 13,85 & 8,56 & 1,29 & 7,00 & 7,59 & 5,30 & 0,44 & 5,34 & 4,60 & 4,86 & 12,37 \\
\hline $\mathrm{jul} / 01$ & 13,86 & 8,46 & 1,29 & 6,99 & 7,67 & 5,27 & 0,45 & 5,37 & 4,60 & 4,86 & 12,55 \\
\hline ago/01 & 13,86 & 8,32 & 1,28 & 6,92 & 7,84 & 5,22 & 0,44 & 5,33 & 4,56 & 4,82 & 12,79 \\
\hline set/01 & 13,90 & 8,31 & 1,29 & 6,90 & 7,88 & 5,19 & 0,45 & 5,32 & 4,51 & 4,80 & 12,84 \\
\hline out $/ 01$ & 13,92 & 8,31 & 1,30 & 6,90 & 7,91 & 5,19 & 0,45 & 5,31 & 4,49 & 4,76 & 12,86 \\
\hline nov/01 & 14,03 & 8,27 & 1,30 & 6,86 & 7,92 & 5,21 & 0,44 & 5,30 & 4,43 & 4,74 & 12,98 \\
\hline $\mathrm{dez} / 01$ & 14,19 & 8,24 & 1,31 & 6,83 & 7,94 & 5,23 & 0,44 & 5,31 & 4,41 & 4,73 & 12,93 \\
\hline $\mathrm{jan} / 02$ & 14,18 & 8,23 & 1,32 & 6,79 & 7,93 & 5,27 & & 5,38 & 4,42 & 4,73 & 12,92 \\
\hline fev/02 & 14,17 & 8,31 & 1,33 & 6,75 & 8,33 & 5,30 & 0,44 & 5,38 & 4,42 & 4,73 & 12,49 \\
\hline $\mathrm{mar} / 02$ & 14,12 & 8,32 & 1,34 & 6,73 & 8,32 & 5,31 & 0,44 & 5,33 & 4,42 & 4,74 & 12,29 \\
\hline $\mathrm{abr} / 02$ & 14,04 & 8,35 & 1,34 & 6,71 & 8,39 & 5,27 & 0,44 & 5,29 & 4,39 & 4,75 & 12,40 \\
\hline $\mathrm{mai} / 02$ & 13,85 & 8,29 & 1,34 & 6,68 & 8,52 & 5,23 & 0,44 & 5,30 & 4,37 & 4,77 & 12,66 \\
\hline jun/02 & 13,74 & 8,23 & 1,34 & 6,68 & 8,53 & 5,26 & 0,44 & 5,37 & 4,35 & 4,81 & 12,67 \\
\hline $\mathrm{jul} / 02$ & 13,72 & 8,18 & 1,34 & 6,66 & 8,66 & 5,24 & 0,44 & 5,42 & 4,30 & 4,77 & 12,74 \\
\hline ago/02 & 13,71 & 8,16 & 1,33 & 6,61 & 8,83 & 5,19 & 0,44 & 5,40 & 4,24 & 4,74 & 12,69 \\
\hline set/02 & 14,02 & 8,12 & 1,33 & 6,58 & 8,81 & 5,19 & 0,44 & 5,38 & 4,20 & 4,72 & 12,58 \\
\hline out $/ 02$ & 14,30 & 8,11 & 1,35 & 6,53 & 8,67 & 5,25 & 0,44 & 5,37 & 4,18 & 4,72 & 12,52 \\
\hline nov/02 & 14,65 & 8,09 & 1,35 & 6,45 & 8,59 & 5,31 & 0,43 & 5,37 & 4,10 & 4,66 & 12,64 \\
\hline $\mathrm{dez} / 02$ & 15,22 & 8,14 & 1,34 & 6,27 & 8,61 & 5,31 & 0,42 & 5,26 & 4,06 & 4,56 & 13,12 \\
\hline $\operatorname{jan} / 03$ & 15,54 & 8,24 & & & & 5,31 & & 5,20 & 4 & 4,45 & 13,09 \\
\hline fev/03 & 15,44 & 8,31 & 1,36 & 6,06 & & 5,29 & & 5,13 & 4,01 & 4,39 & 13,59 \\
\hline $\mathrm{mar} / 03$ & 15,33 & 8,34 & 1,37 & 5,99 & 8,45 & 5,30 & 0,41 & 5,06 & 3,96 & 4,32 & 14,03 \\
\hline $\mathrm{abr} / 03$ & 15,30 & 8,47 & 1,39 & 5,95 & 8,45 & 5,30 & 0,41 & 5,03 & 3,94 & 4,25 & 13,99 \\
\hline $\mathrm{mai} / 03$ & 15,26 & 8,51 & 1,42 & 5,91 & 8,62 & 5,29 & 0,41 & 5,03 & 3,95 & 4,21 & 13,93 \\
\hline jun/03 & 15,39 & 8,39 & 1,42 & 5,91 & 8,88 & 5,27 & 0,41 & 5,05 & 3,93 & 4,21 & 13,74 \\
\hline $\mathrm{jul} / 03$ & 15,46 & 8,27 & 1,43 & 5,97 & 8,92 & 5,28 & 0,41 & 5,16 & 3,94 & 4,23 & 13,43 \\
\hline ago/03 & 15,36 & 8,16 & 1,43 & 5,99 & 9,00 & 5,27 & 0,40 & 5,17 & 3,94 & 4,26 & 13,21 \\
\hline set/03 & 15,31 & 8,07 & 1,43 & 5,98 & 9,12 & 5,26 & 0,41 & 5,15 & 3,91 & 4,27 & 13,19 \\
\hline out $/ 03$ & 15,37 & 8,01 & 1,42 & 5,97 & 9,21 & 5,23 & 0,40 & 5,15 & 3,86 & 4,24 & 13,24 \\
\hline nov/03 & 15,44 & 7,98 & 1,41 & 5,98 & 9,23 & 5,24 & 0,40 & 5,18 & 3,83 & 4,22 & 13,15 \\
\hline $\mathrm{dez} / 03$ & 15,41 & 7,99 & 1,41 & 5,99 & 9,21 & 5,22 & 0,41 & 5,22 & 3,82 & 4,22 & 13,12 \\
\hline $\mathrm{jan} / 04$ & 15,36 & 8,00 & 1,41 & 5,99 & & 5,20 & 0,41 & 5,24 & 3,81 & 4,24 & 13,15 \\
\hline fev/04 & 15,31 & 8,08 & 1,41 & 5,98 & 9,24 & 5,18 & 0,41 & 5,20 & 3,84 & 4,24 & 13,12 \\
\hline $\mathrm{mar} / 04$ & 15,16 & 8,12 & 1,39 & 5,96 & 9,23 & 5,17 & 0,41 & 5,16 & 3,87 & 4,29 & 13,03 \\
\hline $\mathrm{abr} / 04$ & 15,11 & 8,17 & 1,40 & 5,95 & 9,26 & 5,18 & 0,41 & 5,15 & 3,93 & 4,32 & 12,82 \\
\hline mai/04 & 14,99 & 8,12 & 1,40 & 5,94 & 9,35 & 5,18 & 0,41 & 5,19 & 3,95 & 4,34 & 12,73 \\
\hline jun/04 & 14,96 & 8,09 & 1,40 & 5,92 & 9,37 & 5,16 & 0,41 & 5,23 & 3,97 & 4,38 & 12,67 \\
\hline $\mathrm{jul} / 04$ & 15,00 & 8,06 & 1,40 & 5,89 & 9,32 & 5,16 & 0,41 & 5,26 & 3,99 & 4,36 & 12,84 \\
\hline ago/04 & 14,98 & 8,02 & 1,40 & 5,85 & 9,42 & 5,14 & 0,40 & 5,24 & 3,98 & 4,35 & 12,89 \\
\hline set/04 & 14,93 & 8,12 & 1,40 & 5,84 & 9,38 & 5,10 & 0,40 & 5,23 & 3,98 & 4,35 & 13,00 \\
\hline out $/ 04$ & 14,91 & 8,01 & 1,40 & 5,81 & 9,40 & 5,12 & 0,40 & 5,26 & 4,01 & 4,38 & 12,95 \\
\hline nov/04 & 14,84 & 7,94 & 1,41 & 5,81 & 9,40 & 5,13 & 0,40 & 5,30 & 4,04 & 4,38 & 13,03 \\
\hline $\mathrm{dez} / 04$ & 14,74 & 7,88 & 1,41 & 5,80 & 9,35 & 5,12 & 0,39 & 5,31 & 4,04 & 4,40 & 13,22 \\
\hline
\end{tabular}

Economia e Sociedade, Campinas, v. 22, n. 2 (48), p. 409-456, ago. 2013. 
Thiago Sevilhano Martinez / Vinícius dos Santos Cerqueira

Continuação

\begin{tabular}{|c|c|c|c|c|c|c|c|c|c|c|c|}
\hline \multicolumn{9}{|c|}{ Grupos do IPCA } & \multicolumn{3}{|c|}{ Tipo de precificação } \\
\hline \multicolumn{3}{|c|}{ 1.Alimentação e bebidas } & \multicolumn{3}{|c|}{ 4.Vestuário } & \multicolumn{3}{|c|}{ 7.Despesas pessoais } & \multicolumn{3}{|c|}{ c. Comercializáveis } \\
\hline \multicolumn{3}{|c|}{ 2.Habitação } & \multicolumn{3}{|c|}{ 5.Transportes } & 8.Edu & & & nc. Não-con & cializáv & \\
\hline & de resi & & 6.Saú & cuidad & pessoais & 9.Cor & icação & & m. Monitor & & \\
\hline & 6.c & $6 . \mathrm{nc}$ & $6 . \mathrm{m}$ & $7 . c$ & 7.nc & $7 . \mathrm{m}$ & $8 . \mathrm{c}$ & $8 . \mathrm{nc}$ & $9 . \mathrm{c}$ & 9.nc & $9 . \mathrm{m}$ \\
\hline ago/99 & 6,70 & 2,10 & 2,68 & 2,58 & 6,90 & 0,42 & 0,19 & 4,78 & 0,03 & 0,02 & 3,37 \\
\hline set/99 & 6,76 & 2,09 & 2,66 & 2,55 & 6,87 & 0,42 & 0,19 & 4,78 & 0,03 & 0,02 & 3,35 \\
\hline out/99 & 6,77 & 2,10 & 2,69 & 2,54 & 6,84 & 0,42 & 0,19 & 4,76 & 0,03 & 0,02 & 3,34 \\
\hline nov/99 & 6,72 & 2,08 & 2,66 & 2,52 & 6,76 & 0,41 & 0,19 & 4,71 & 0,02 & 0,02 & 3,29 \\
\hline $\operatorname{dez} / 99$ & 6,68 & 2,06 & 2,64 & 2,50 & 6,70 & 0,41 & 0,20 & 4,66 & 0,02 & 0,02 & 3,26 \\
\hline $\mathrm{jan} / 00$ & 6,66 & 2,05 & 2,64 & 2,50 & 6,68 & 0,41 & 0,20 & 4,66 & 0,02 & 0,02 & 3,24 \\
\hline fev/00 & 6,66 & 2,04 & 2,64 & 2,49 & 6,64 & 0,40 & 0,20 & 4,77 & 0,02 & 0,02 & 3,28 \\
\hline $\mathrm{mar} / 00$ & 6,67 & 2,04 & 2,64 & 2,51 & 6,65 & 0,40 & 0,20 & 4,83 & 0,02 & 0,02 & 3,27 \\
\hline $\mathrm{abr} / 00$ & 6,66 & 2,04 & 2,65 & 2,50 & 6,63 & 0,40 & 0,20 & 4,80 & 0,02 & 0,02 & 3,27 \\
\hline $\mathrm{mai} / 00$ & 6,63 & 2,04 & 2,64 & 2,49 & 6,94 & 0,40 & 0,20 & 4,78 & 0,02 & 0,02 & 3,25 \\
\hline jun/00 & 6,64 & 2,04 & 2,64 & 2,49 & 6,95 & 0,40 & 0,20 & 4,78 & 0,02 & 0,02 & 3,25 \\
\hline $\mathrm{jul} / 00$ & 6,68 & 2,03 & 2,63 & 2,48 & 6,95 & 0,39 & 0,20 & 4,76 & 0,02 & 0,02 & 3,33 \\
\hline ago/00 & 6,60 & 2,01 & 2,60 & 2,45 & 6,86 & 0,38 & 0,20 & 4,67 & 0,02 & 0,02 & 3,53 \\
\hline set/00 & 6,52 & 1,99 & 2,66 & 2,42 & 6,79 & 0,38 & 0,20 & 4,62 & 0,02 & 0,02 & 3,48 \\
\hline out $/ 00$ & 6,49 & 1,98 & 2,66 & 2,42 & 6,79 & 0,37 & 0,20 & 4,62 & 0,02 & 0,02 & 3,48 \\
\hline nov $/ 00$ & 6,47 & 1,98 & 2,65 & 2,43 & 6,79 & 0,37 & 0,20 & 4,62 & 0,02 & 0,02 & 3,48 \\
\hline $\mathrm{dez} / 00$ & 6,44 & 1,98 & 2,64 & 2,42 & 6,77 & 0,37 & 0,20 & 4,62 & 0,02 & 0,02 & 3,47 \\
\hline $\mathrm{jan} / 01$ & 6,38 & 1,97 & 2,63 & 2,42 & 6,77 & 0,37 & 0,20 & 4,59 & 0,02 & 0,02 & 3,45 \\
\hline fev/01 & 6,36 & 1,97 & 2,62 & 2,41 & 6,75 & 0,37 & 0,20 & 4,63 & 0,02 & 0,02 & 3,44 \\
\hline $\operatorname{mar} / 01$ & 6,40 & 1,97 & 2,60 & 2,40 & 6,74 & 0,37 & 0,20 & 4,75 & 0,02 & 0,02 & 3,43 \\
\hline $\mathrm{abr} / 01$ & 6,44 & 1,95 & 2,59 & 2,40 & 6,71 & 0,37 & 0,20 & 4,75 & 0,02 & 0,02 & 3,42 \\
\hline $\mathrm{mai} / 01$ & 6,42 & 1,95 & 2,58 & 2,40 & 6,76 & 0,37 & 0,21 & 4,75 & 0,02 & 0,02 & 3,40 \\
\hline jun/01 & 6,39 & 1,94 & 2,57 & 2,40 & 6,76 & 0,37 & 0,21 & 4,74 & 0,02 & 0,02 & 3,39 \\
\hline jul/01 & 6,28 & 1,94 & 2,56 & 2,40 & 6,72 & 0,37 & 0,20 & 4,72 & 0,02 & 0,02 & 3,41 \\
\hline ago/01 & 6,21 & 1,91 & 2,54 & 2,38 & 6,74 & 0,36 & 0,21 & 4,66 & 0,02 & 0,02 & 3,55 \\
\hline set/01 & 6,23 & 1,90 & 2,54 & 2,37 & 6,78 & 0,36 & 0,21 & 4,65 & 0,02 & 0,02 & 3,54 \\
\hline out/01 & 6,22 & 1,91 & 2,55 & 2,38 & 6,77 & 0,36 & 0,21 & 4,65 & 0,02 & 0,02 & 3,52 \\
\hline nov/01 & 6,18 & 1,89 & 2,55 & 2,44 & 6,75 & 0,35 & 0,20 & 4,62 & 0,02 & 0,02 & 3,49 \\
\hline $\mathrm{dez} / 01$ & 6,16 & 1,88 & 2,55 & 2,49 & 6,70 & 0,35 & 0,20 & 4,60 & 0,02 & 0,02 & 3,47 \\
\hline $\mathrm{jan} / 02$ & 6,21 & 1,88 & 2,55 & 2,48 & 6,66 & 0,35 & 0,20 & 4,57 & 0,02 & 0,02 & 3,45 \\
\hline fev/02 & 6,19 & 1,87 & 2,54 & 2,49 & 6,66 & 0,35 & 0,20 & 4,57 & 0,02 & 0,02 & 3,44 \\
\hline $\mathrm{mar} / 02$ & 6,27 & 1,87 & 2,55 & 2,49 & 6,66 & 0,35 & 0,20 & 4,77 & 0,02 & 0,02 & 3,45 \\
\hline $\mathrm{abr} / 02$ & 6,34 & 1,86 & 2,56 & 2,48 & 6,59 & 0,35 & 0,20 & 4,78 & 0,02 & 0,02 & 3,43 \\
\hline $\mathrm{mai} / 02$ & 6,34 & 1,85 & 2,56 & 2,46 & 6,58 & 0,35 & 0,20 & 4,76 & 0,02 & 0,02 & 3,40 \\
\hline jun/02 & 6,32 & 1,85 & 2,58 & 2,46 & 6,63 & 0,35 & 0,20 & 4,77 & 0,02 & 0,02 & 3,39 \\
\hline $\mathrm{jul} / 02$ & 6,30 & 1,85 & 2,58 & 2,44 & 6,64 & 0,34 & 0,20 & 4,76 & 0,02 & 0,02 & 3,38 \\
\hline ago/02 & 6,26 & 1,83 & 2,57 & 2,41 & 6,66 & 0,34 & 0,20 & 4,71 & 0,02 & 0,02 & 3,66 \\
\hline set/02 & 6,24 & 1,84 & 2,57 & 2,40 & 6,65 & 0,34 & 0,20 & 4,69 & 0,02 & 0,02 & 3,65 \\
\hline out/02 & 6,22 & 1,85 & 2,57 & 2,41 & 6,64 & 0,34 & 0,20 & 4,67 & 0,02 & 0,02 & 3,63 \\
\hline nov/02 & 6,18 & 1,84 & 2,55 & 2,45 & 6,59 & 0,34 & 0,20 & 4,62 & 0,02 & 0,02 & 3,58 \\
\hline $\mathrm{dez} / 02$ & 6,05 & 1,80 & 2,49 & 2,39 & 6,41 & 0,33 & 0,20 & 4,49 & 0,02 & 0,02 & 3,48 \\
\hline $\mathrm{jan} / 03$ & 6,17 & 1,78 & 2,46 & 2,48 & 6,34 & 0,32 & 0,19 & 4,41 & 0,02 & 0,02 & 3,41 \\
\hline fev/03 & 6,16 & 1,75 & 2,42 & 2,48 & 6,30 & 0,34 & 0,19 & 4,36 & 0,02 & 0,02 & 3,34 \\
\hline mar/03 & 6,11 & 1,73 & 2,40 & 2,45 & 6,23 & 0,35 & 0,19 & 4,55 & 0,02 & 0,02 & 3,40 \\
\hline $\mathrm{abr} / 03$ & 6,26 & 1,71 & 2,39 & 2,44 & 6,20 & 0,34 & 0,20 & 4,53 & 0,02 & 0,02 & 3,41 \\
\hline $\mathrm{mai} / 03$ & 6,33 & 1,70 & 2,38 & 2,43 & 6,16 & 0,34 & 0,20 & 4,50 & 0,02 & 0,02 & 3,38 \\
\hline jun/03 & 6,34 & 1,71 & 2,38 & 2,44 & 6,11 & 0,34 & 0,19 & 4,49 & 0,02 & 0,02 & 3,36 \\
\hline $\mathrm{jul} / 03$ & 6,36 & 1,72 & 2,40 & 2,43 & 6,15 & 0,34 & 0,20 & 4,50 & 0,02 & 0,02 & 3,37 \\
\hline ago/03 & 6,37 & 1,71 & 2,41 & 2,40 & 6,18 & 0,34 & 0,20 & 4,51 & 0,02 & 0,02 & 3,65 \\
\hline set/03 & 6,35 & 1,71 & 2,42 & 2,43 & 6,23 & 0,33 & 0,20 & 4,51 & 0,02 & 0,02 & 3,69 \\
\hline out $/ 03$ & 6,33 & 1,71 & 2,42 & 2,44 & 6,20 & 0,33 & 0,20 & 4,49 & 0,02 & 0,02 & 3,74 \\
\hline nov/03 & 6,35 & 1,71 & 2,43 & 2,45 & 6,23 & 0,33 & 0,19 & 4,47 & 0,02 & 0,02 & 3,73 \\
\hline $\mathrm{dez} / 03$ & 6,32 & 1,72 & 2,44 & 2,48 & 6,23 & 0,38 & 0,20 & 4,46 & 0,02 & 0,02 & 3,72 \\
\hline jan/04 & 6,31 & 1,73 & 2,45 & 2,53 & 6,24 & 0,40 & 0,20 & 4,45 & 0,02 & 0,02 & 3,70 \\
\hline fev/04 & 6,28 & 1,72 & 2,45 & 2,54 & 6,24 & 0,40 & 0,20 & 4,44 & 0,02 & 0,02 & 3,68 \\
\hline $\mathrm{mar} / 04$ & 6,24 & 1,73 & 2,45 & 2,56 & 6,20 & 0,40 & 0,20 & 4,72 & 0,02 & 0,02 & 3,68 \\
\hline $\mathrm{abr} / 04$ & 6,26 & 1,73 & 2,46 & 2,61 & 6,20 & 0,40 & 0,20 & 4,73 & 0,02 & 0,02 & 3,69 \\
\hline $\mathrm{mai} / 04$ & 6,37 & 1,73 & 2,47 & 2,61 & 6,20 & 0,40 & 0,20 & 4,73 & 0,02 & 0,02 & 3,68 \\
\hline jun/04 & 6,45 & 1,72 & 2,48 & 2,60 & 6,17 & 0,39 & 0,20 & 4,71 & 0,02 & 0,02 & 3,66 \\
\hline $\mathrm{jul} / 04$ & 6,42 & 1,72 & 2,48 & 2,59 & 6,15 & 0,39 & 0,20 & 4,69 & 0,02 & 0,02 & 3,64 \\
\hline ago/04 & 6,39 & 1,71 & 2,48 & 2,56 & 6,14 & 0,39 & 0,20 & 4,66 & 0,02 & 0,02 & 3,77 \\
\hline set/04 & 6,36 & 1,71 & 2,48 & 2,54 & 6,16 & 0,39 & 0,20 & 4,65 & 0,02 & 0,02 & 3,77 \\
\hline out $/ 04$ & 6,31 & 1,71 & 2,50 & 2,54 & 6,17 & 0,39 & 0,20 & 4,64 & 0,02 & 0,02 & 3,86 \\
\hline nov/04 & 6,30 & 1,70 & 2,51 & 2,55 & 6,18 & 0,38 & 0,20 & 4,62 & 0,02 & 0,02 & 3,87 \\
\hline $\mathrm{dez} / 04$ & 6,26 & 1,70 & 2,51 & 2,58 & 6,14 & 0,38 & 0,20 & 4,59 & 0,02 & 0,02 & 3,94 \\
\hline
\end{tabular}


Estrutura da inflação brasileira: determinantes e desagregação do IPCA

Classificação do IPCA por Segmentos - Pesos (jan/05 - dez/09)

\begin{tabular}{|c|c|c|c|c|c|c|c|c|c|c|c|}
\hline \multicolumn{8}{|c|}{ Grupos do IPCA } & \multicolumn{3}{|c|}{ Tipo de precificação } & \\
\hline \multicolumn{3}{|c|}{ 1.Alimentação e bebidas } & \multicolumn{3}{|c|}{ 4.Vestuário } & \multicolumn{2}{|c|}{ 7.Despesas pessoais } & \multicolumn{3}{|c|}{ c. Comercializáveis } & \\
\hline \multicolumn{3}{|c|}{ 2.Habitação } & \multicolumn{3}{|c|}{ 5.Transportes } & \multicolumn{2}{|c|}{ 8.Educação } & \multicolumn{3}{|c|}{ nc. Não-comercializáveis } & \\
\hline \multicolumn{3}{|c|}{ 3.Artigos de residência } & 6.Saúd & cuidado & essoais & 9.Comu & ação & $\mathrm{m}$. & onitorado & & \\
\hline & $1 . \mathrm{c}$ & $1 . \mathrm{nc}$ & 2.c & $2 . \mathrm{nc}$ & $2 . \mathrm{m}$ & $3 . \mathrm{c}$ & $3 . \mathrm{nc}$ & 4.c & $5 . \mathrm{c}$ & $5 . \mathrm{nc}$ & $5 . \mathrm{m}$ \\
\hline $\mathrm{jan} / 05$ & 14,71 & 7,86 & 1,41 & 5,78 & 9,31 & 5,10 & 0,40 & 5,35 & 4,03 & 4,39 & 13,44 \\
\hline fev/05 & 14,67 & 7,94 & 1,41 & 5,77 & 9,32 & 5,11 & 0,39 & 5,33 & 4,05 & 4,39 & 13,42 \\
\hline $\operatorname{mar} / 05$ & 14,55 & 8,05 & 1,42 & 5,76 & 9,30 & 5,11 & 0,40 & 5,29 & 4,04 & 4,39 & 13,32 \\
\hline $\mathrm{abr} / 05$ & 14,47 & 8,05 & 1,43 & 5,76 & 9,33 & 5,09 & 0,40 & 5,29 & 4,03 & 4,38 & 13,50 \\
\hline mai/05 & 14,46 & 8,05 & 1,42 & 5,72 & 9,36 & 5,07 & 0,39 & 5,29 & 4,02 & 4,38 & 13,55 \\
\hline jun/05 & 14,46 & 8,08 & 1,42 & 5,70 & 9,40 & 5,08 & 0,39 & 5,34 & 4,01 & 4,38 & 13,46 \\
\hline $\mathrm{jul} / 05$ & 14,38 & 8,01 & 1,43 & 5,72 & 9,44 & 5,09 & 0,40 & 5,36 & 4,03 & 4,42 & 13,33 \\
\hline ago/05 & 14,21 & 7,96 & 1,43 & 5,73 & 9,40 & 5,09 & 0,40 & 5,36 & 4,03 & 4,45 & 13,38 \\
\hline set/05 & 14,09 & 7,88 & 1,42 & 5,74 & 9,43 & 5,09 & 0,40 & 5,35 & 4,02 & 4,45 & 13,45 \\
\hline out $/ 05$ & 14,02 & 7,81 & 1,42 & 5,75 & 9,47 & 5,06 & 0,40 & 5,34 & 4,00 & 4,45 & 13,59 \\
\hline nov/05 & 14,02 & 7,71 & 1,41 & 5,74 & 9,44 & 5,00 & 0,39 & 5,34 & 3,98 & 4,47 & 13,90 \\
\hline $\mathrm{dez} / 05$ & 13,98 & 7,82 & 1,41 & 5,73 & 9,47 & 4,94 & 0,39 & 5,36 & 3,95 & 4,45 & 13,97 \\
\hline $\mathrm{jan} / 06$ & 13,92 & 7,87 & 1,40 & 5,73 & 9,48 & 4,95 & 0,39 & 5,42 & 5,09 & 4,41 & 12,85 \\
\hline fev/06 & 13,74 & 7,94 & 1,40 & 5,72 & 9,39 & 4,95 & 0,39 & 5,39 & 5,22 & 4,41 & 12,93 \\
\hline mar/06 & 13,65 & 7,88 & 1,39 & 5,74 & 9,37 & 4,90 & 0,40 & 5,34 & 5,24 & 4,44 & 12,96 \\
\hline $\mathrm{abr} / 06$ & 13,52 & 7,86 & 1,38 & 5,73 & 9,41 & 4,88 & 0,39 & 5,33 & 5,37 & 4,41 & 13,02 \\
\hline mai/06 & 13,41 & 7,87 & 1,39 & 5,75 & 9,46 & 4,83 & 0,39 & 5,38 & 5,36 & 4,40 & 12,99 \\
\hline jun/06 & 13,46 & 7,79 & 1,38 & 5,76 & 9,48 & 4,79 & 0,39 & 5,42 & 5,22 & 4,41 & 13,01 \\
\hline $\mathrm{jul} / 06$ & 11,15 & 9,14 & 1,05 & 5,86 & 6,80 & 4,38 & 0,45 & 6,52 & 4,75 & 4,04 & 12,17 \\
\hline ago/06 & 11,15 & 9,12 & 1,05 & 5,86 & 6,77 & 4,37 & 0,45 & 6,50 & 4,73 & 4,03 & 12,24 \\
\hline set/06 & 11,16 & 9,11 & 1,05 & 5,87 & 6,77 & 4,37 & 0,45 & 6,50 & 4,70 & 4,01 & 12,21 \\
\hline out/06 & 11,18 & 9,07 & 1,04 & 5,88 & 6,79 & 4,35 & 0,45 & 6,52 & 4,68 & 4,01 & 12,18 \\
\hline nov/06 & 11,23 & 9,13 & 1,04 & 5,88 & 6,78 & 4,32 & 0,45 & 6,54 & 4,66 & 3,98 & 12,14 \\
\hline $\mathrm{dez} / 06$ & 11,30 & 9,20 & 1,03 & 5,87 & 6,74 & 4,31 & 0,45 & 6,56 & 4,65 & 3,95 & 12,10 \\
\hline jan/07 & 11,30 & 9,19 & 1,03 & 5,86 & 6,71 & 4,28 & 0,45 & 6,59 & 4,64 & 3,93 & 12,26 \\
\hline fev/07 & 11,28 & 9,29 & 1,03 & 5,88 & 6,64 & 4,27 & 0,44 & 6,55 & 4,64 & 3,93 & 12,29 \\
\hline $\mathrm{mar} / 07$ & 11,25 & 9,39 & 1,03 & 5,88 & 6,61 & 4,24 & 0,44 & 6,48 & 4,62 & 3,90 & 12,26 \\
\hline $\mathrm{abr} / 07$ & 11,25 & 9,52 & 1,03 & 5,90 & 6,59 & 4,21 & 0,43 & 6,48 & 4,61 & 3,89 & 12,26 \\
\hline mai/07 & 11,24 & 9,48 & 1,03 & 5,90 & 6,60 & 4,19 & 0,43 & 6,48 & 4,62 & 3,88 & 12,27 \\
\hline jun/07 & 11,28 & 9,41 & 1,04 & 5,88 & 6,60 & 4,17 & 0,43 & 6,51 & 4,62 & 3,87 & 12,27 \\
\hline $\mathrm{jul} / 07$ & 11,42 & 9,44 & 1,03 & 5,89 & 6,58 & 4,13 & 0,42 & 6,55 & 4,56 & 3,86 & 12,20 \\
\hline ago/07 & 11,70 & 9,38 & 1,03 & 5,89 & 6,46 & 4,11 & 0,42 & 6,53 & 4,53 & 3,85 & 12,18 \\
\hline set/07 & 11,87 & 9,39 & 1,03 & 5,88 & 6,41 & 4,09 & 0,41 & 6,49 & 4,50 & 3,86 & 12,11 \\
\hline out/07 & 11,89 & 9,43 & 1,03 & 5,92 & 6,42 & 4,09 & 0,41 & 6,51 & 4,51 & 3,83 & 12,07 \\
\hline nov/07 & 11,77 & 9,59 & 1,02 & 5,95 & 6,36 & 4,08 & 0,41 & 6,54 & 4,50 & 3,81 & 12,06 \\
\hline $\mathrm{dez} / 07$ & 11,76 & 9,68 & 1,02 & 5,98 & 6,34 & 4,05 & 0,41 & 6,55 & 4,50 & 3,82 & 12,05 \\
\hline $\mathrm{jan} / 08$ & 11,88 & 9,84 & 1,01 & 5,97 & 6,28 & 4,00 & 0,41 & 6,54 & 4,53 & 3,79 & 12,05 \\
\hline fev/08 & 11,89 & 10,04 & 1,01 & 5,97 & 6,23 & 3,98 & 0,41 & 6,50 & 4,51 & 3,79 & 12,03 \\
\hline $\mathrm{mar} / 08$ & 11,86 & 10,09 & 1,01 & 5,96 & 6,20 & 3,96 & 0,40 & 6,44 & 4,50 & 3,80 & 11,96 \\
\hline $\mathrm{abr} / 08$ & 11,91 & 10,13 & 1,00 & 5,95 & 6,24 & 3,93 & 0,40 & 6,45 & 4,48 & 3,81 & 11,95 \\
\hline mai/08 & 12,04 & 10,15 & 1,01 & 5,95 & 6,20 & 3,92 & 0,40 & 6,52 & 4,46 & 3,78 & 11,89 \\
\hline jun/08 & 12,28 & 10,17 & 1,02 & 5,92 & 6,15 & 3,89 & 0,40 & 6,53 & 4,44 & 3,76 & 11,83 \\
\hline $\mathrm{jul} / 08$ & 12,50 & 10,25 & 1,02 & 5,91 & 6,10 & 3,87 & 0,40 & 6,51 & 4,41 & 3,75 & 11,77 \\
\hline ago/08 & 12,56 & 10,32 & 1,02 & 5,90 & 6,11 & 3,85 & 0,40 & 6,47 & 4,40 & 3,73 & 11,79 \\
\hline set/08 & 12,51 & 10,26 & 1,03 & 5,92 & 6,15 & 3,84 & 0,40 & 6,48 & 4,40 & 3,73 & 11,75 \\
\hline out $/ 08$ & 12,44 & 10,21 & 1,04 & 5,95 & 6,14 & 3,84 & 0,40 & 6,51 & 4,38 & 3,77 & 11,76 \\
\hline nov/08 & 12,48 & 10,23 & 1,04 & 5,96 & 6,14 & 3,84 & 0,41 & 6,56 & 4,36 & 3,74 & 11,71 \\
\hline $\mathrm{dez} / 08$ & 12,54 & 10,22 & 1,05 & 5,99 & 6,13 & 3,85 & 0,41 & 6,58 & 4,34 & 3,71 & 11,70 \\
\hline $\mathrm{jan} / 09$ & 12,52 & 10,26 & 1,05 & 6,00 & 6,11 & 3,84 & 0,41 & 6,63 & 4,28 & 3,68 & 11,73 \\
\hline fev/09 & 12,49 & 10,35 & 1,06 & 6,03 & 6,08 & 3,84 & 0,40 & 6,60 & 4,18 & 3,63 & 11,86 \\
\hline $\mathrm{mar} / 09$ & 12,41 & 10,37 & 1,06 & 6,03 & 6,03 & 3,82 & 0,41 & 6,55 & 4,14 & 3,60 & 11,86 \\
\hline $\mathrm{abr} / 09$ & 12,36 & 10,44 & 1,06 & 6,04 & 6,03 & 3,84 & 0,41 & 6,58 & 4,11 & 3,59 & 11,84 \\
\hline mai/09 & 12,30 & 10,42 & 1,05 & 6,04 & 6,06 & 3,79 & 0,41 & 6,62 & 4,07 & 3,58 & 11,77 \\
\hline jun/09 & 12,36 & 10,35 & 1,05 & 6,05 & 6,09 & 3,77 & 0,41 & 6,67 & 4,02 & 3,57 & 11,69 \\
\hline jul/09 & 12,48 & 10,31 & 1,06 & 6,06 & 6,07 & 3,79 & 0,41 & 6,68 & 3,99 & 3,54 & 11,69 \\
\hline ago/09 & 12,47 & 10,25 & 1,05 & 6,07 & 6,17 & 3,80 & 0,41 & 6,66 & 3,98 & 3,53 & 11,69 \\
\hline set/09 & 12,34 & 10,34 & 1,05 & 6,08 & 6,21 & 3,79 & 0,41 & 6,66 & 3,99 & 3,50 & 11,66 \\
\hline out/09 & 12,25 & 10,35 & 1,05 & 6,09 & 6,25 & 3,78 & 0,41 & 6,68 & 4,00 & 3,51 & 11,64 \\
\hline nov/09 & 12,19 & 10,33 & 1,04 & 6,08 & 6,27 & 3,78 & 0,41 & 6,71 & 4,06 & 3,51 & 11,63 \\
\hline dez/09 & 12,10 & 10,46 & 1,03 & 6,06 & 6,26 & 3,78 & 0,41 & 6,72 & 4,08 & 3,50 & 11,67 \\
\hline
\end{tabular}


Thiago Sevilhano Martinez / Vinícius dos Santos Cerqueira

Continuação

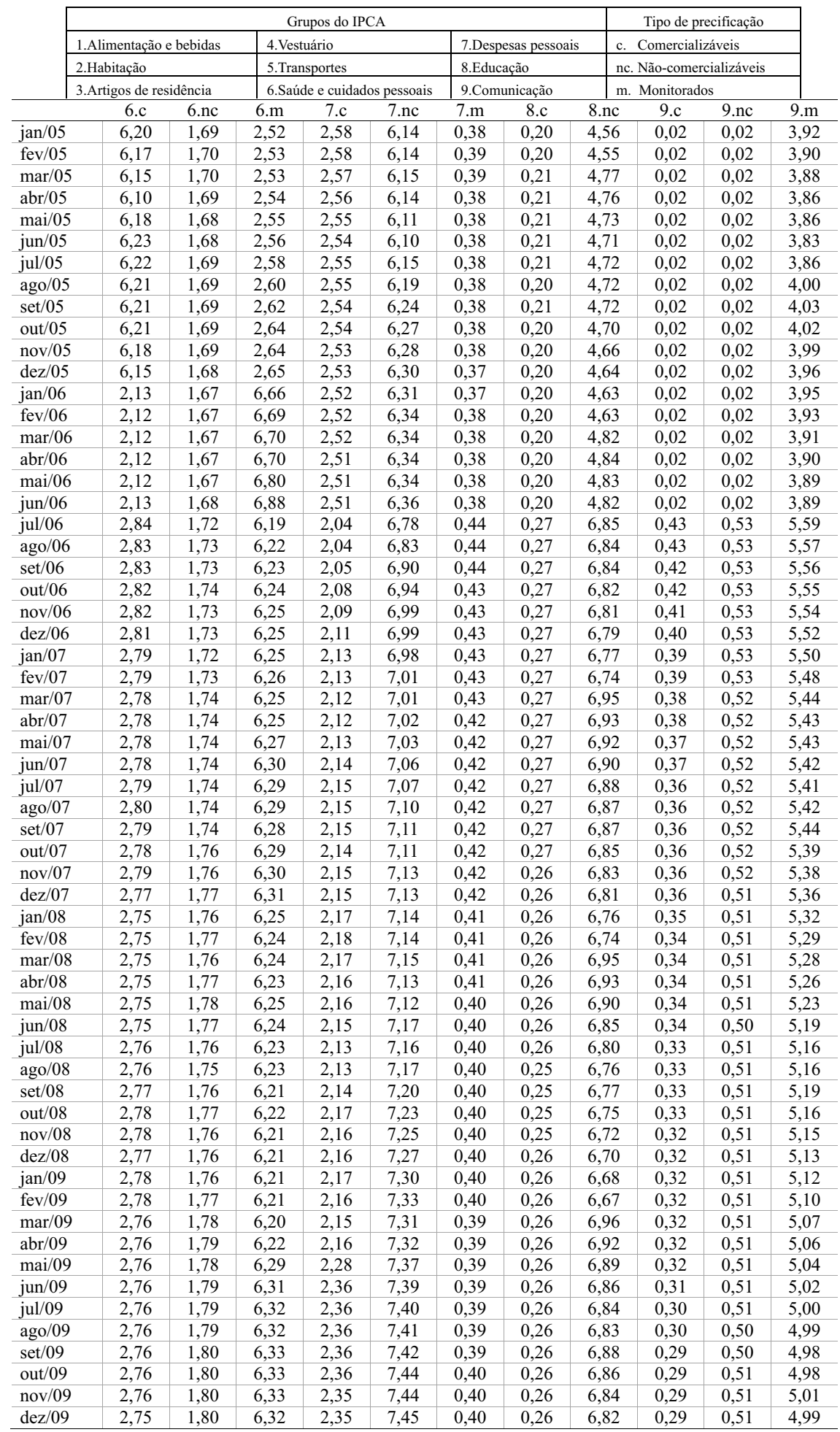

Fonte: IBGE e BCB. Elaboração própria. 